\title{
ZOOTAXA
}

936

A synoptic review of the ants of California (Hymenoptera: Formicidae)

PHILIP S. WARD

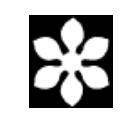

Magnolia Press

Auckland, New Zealand 
PHILIP S. WARD

\section{A synoptic review of the ants of California (Hymenoptera: Formicidae)}

(Zootaxa 936)

68 pp.; $30 \mathrm{~cm}$.

12 Apr. 2005

ISBN 1-877354-98-8 (paperback)

ISBN 1-877354-99-6 (Online edition)

\section{FIRST PUBLISHED IN 2005 BY}

Magnolia Press

P.O. Box 41383

Auckland 1030

New Zealand

e-mail: zootaxa@mapress.com

http://www.mapress.com/zootaxa/

\section{(C) 2005 Magnolia Press}

All rights reserved.

No part of this publication may be reproduced, stored, transmitted or disseminated, in any form, or by any means, without prior written permission from the publisher, to whom all requests to reproduce copyright material should be directed in writing.

This authorization does not extend to any other kind of copying, by any means, in any form, and for any purpose other than private research use.

ISSN 1175-5326 (Print edition)

ISSN 1175-5334 (Online edition) 


\title{
A synoptic review of the ants of California (Hymenoptera: Formicidae)
}

\author{
PHILIP S. WARD
}

Department of Entomology, University of California, Davis, CA 95616, USA; psward@ucdavis.edu

\section{TABLE OF CONTENTS}

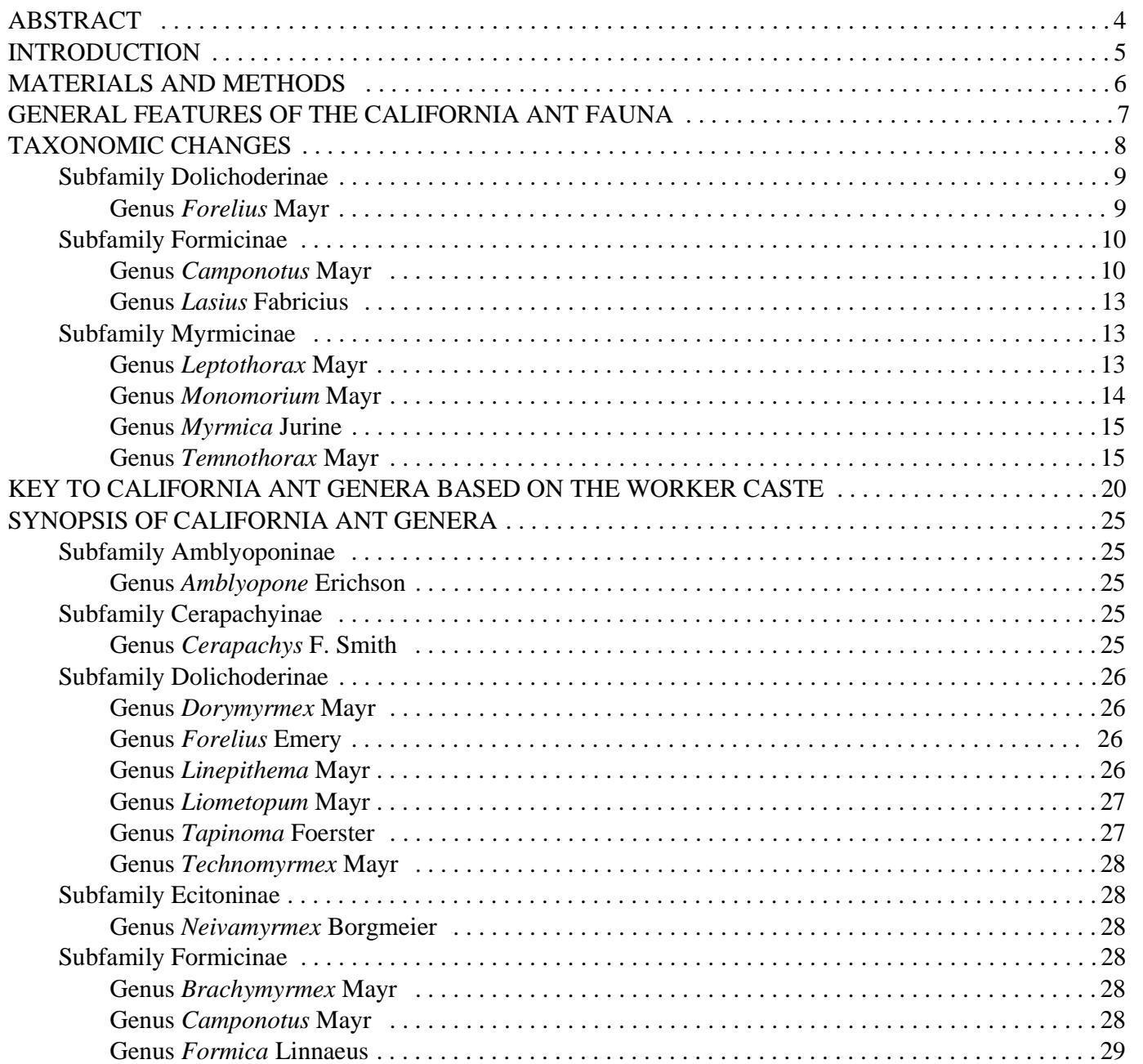




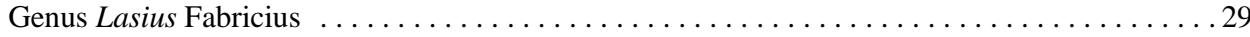

Genus Myrmecocystus Wesmael . . . . . . . . . . . . . . . . . . . . . . . . . . . . 29

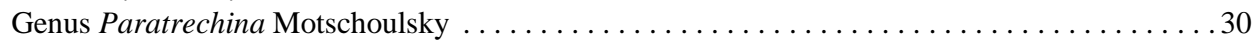

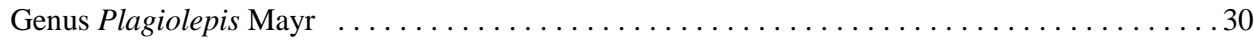

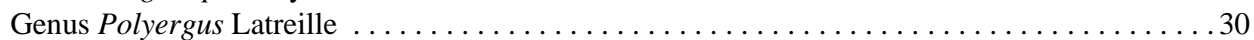

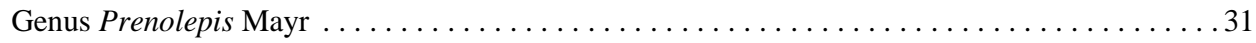

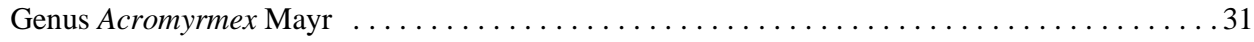

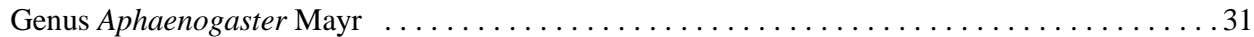

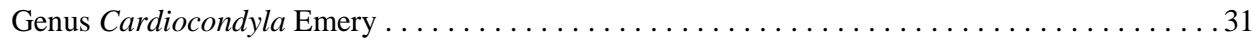

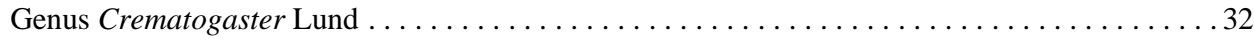

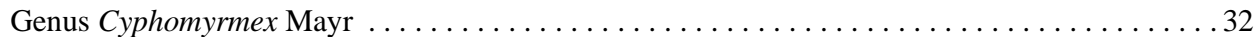

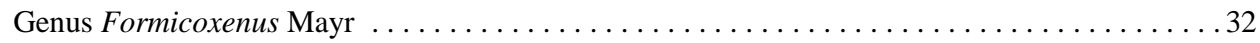

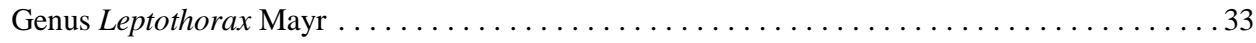

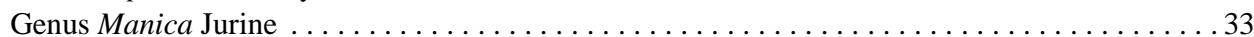

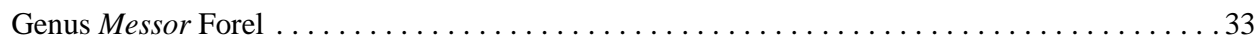

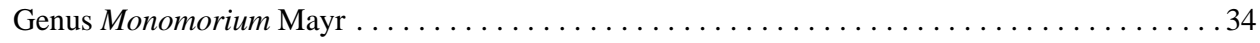

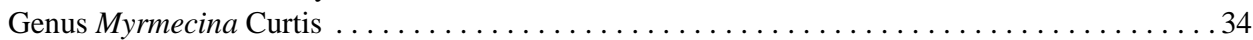

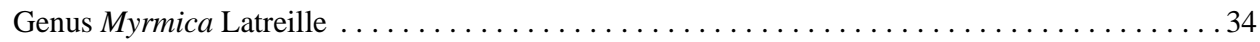

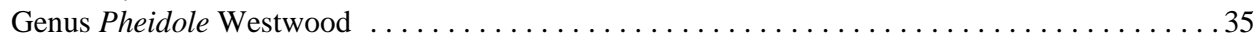

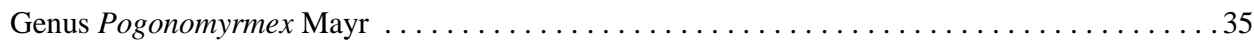

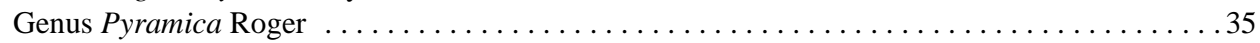

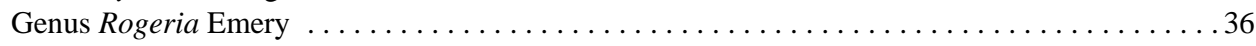

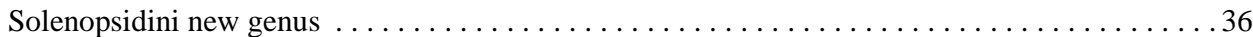

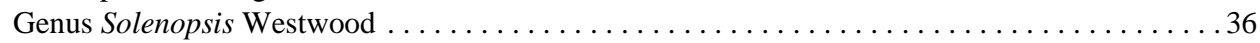

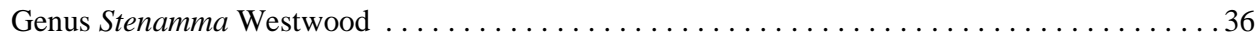

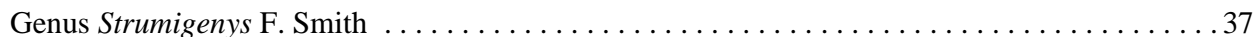

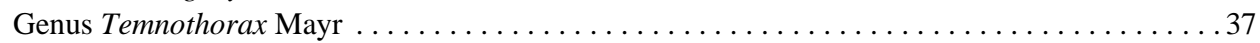

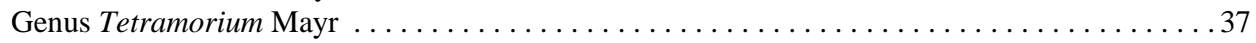

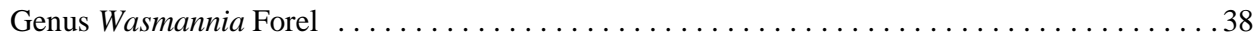

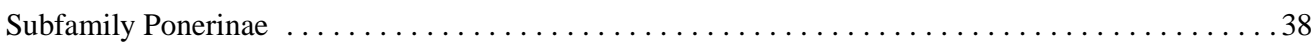

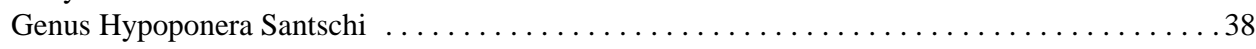

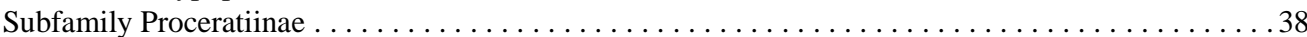

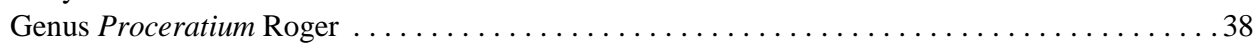

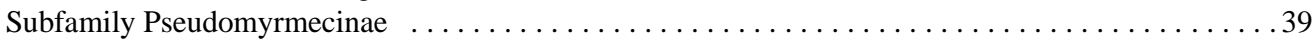

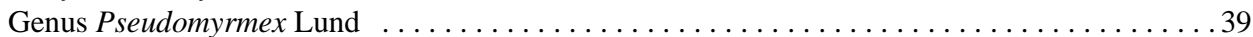

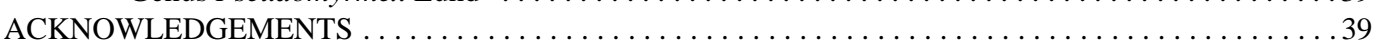

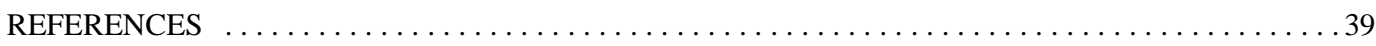

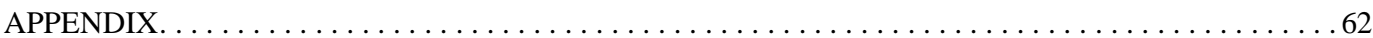

\begin{abstract}
The taxonomy and composition of the California ant fauna is reviewed, leading to the recognition of 281 species (in 44 genera), of which 255 are considered indigenous and 39 are endemic. Species-level endemism $(13.9 \%)$ is higher than in adjacent regions, as is the percentage of non-native species (9.3\%). About one quarter of the indigenous ant species are endemic to the California floristic province (sensu Hickman 1993). Approximately 36 species appear to be undescribed. Most of these undescribed species are assigned code names, which match those used on the "Ants of California" web site (http://www.antweb.org/california.jsp). One new species is described, Camponotus maritimus Ward, sp. nov., which corresponds to the taxon previously called Camponotus maculatus subsp. vicinus var. maritimus Wheeler (unavailable quadrinomen). Three species names are revalidated: Leptothorax calderoni Creighton stat. reval., stat. nov., Myrmica glacialis Emery
\end{abstract}


stat. reval., stat. nov., and Temnothorax rudis (Wheeler) stat. reval., comb. nov. The following new synonymy is proposed (senior synonym listed first): Forelius pruinosus (Roger) = F. analis (André); Monomorium ergatogyna Wheeler = M. wheelerorum DuBois; Temnothorax andrei $($ Emery $)=T$. nitens heathii $($ Wheeler $)=T$. nitens occidentalis $($ Wheeler $)=T$. ocellatus $($ MacKay $)$; Temnothorax nevadensis $($ Wheeler $)=T$. lindae $($ MacKay $)=T$. maryanae $($ MacKay); Temnothorax nitens $($ Emery $)=T$. mariposa $($ Wheeler $)=T$. melinus (MacKay). The genus Acanthomyops Mayr is demoted to subgenus (stat. rev.) within Lasius Fabricius, in accord with recent molecular phylogenetic results. A key to the ant genera of California (based on the worker caste), a synopsis of each genus, a comprehensive bibliography, and a species list are also provided.

Keywords. ant taxonomy, distribution, biogeography, endemism, Camponotus, Lasius, Forelius, Monomorium, Myrmica, Leptothorax, Temnothorax

\section{INTRODUCTION}

Like other components of the California biota, the ant fauna of this state shows considerable biological diversity and regional endemism. Yet there has been no comprehensive systematic treatment of the ants of California, much less a reliable checklist or a set of identification keys. Part of this stems from the complexity of the fauna and an attendant rash of taxonomic problems whose resolution requires additional study at a larger geographical scale. In light of these constraints, the present paper aims to provide no more than a cursory survey of the ant genera, a provisional list of species, and a guide to the literature. A few necessary taxonomic changes are introduced, mostly involving new synonymy at the species level. A prime motivation for this paper stems from the need to establish a reference checklist for a new web site illustrating the ants of California (http:// www.antweb.org/california.jsp). This web site, developed in collaboration with Brian Fisher (California Academy of Sciences), is designed to facilitate identification by providing high-quality digital images of the known California ant species.

The first descriptions of California ants appeared in the nineteenth and early twentieth century, in widely scattered taxonomic papers by Buckley, Emery, Forel, Mayr, W. M. Wheeler and others. Mallis (1941) and Cook (1953) published a species list and a booklength treatment, respectively, of the ants of California but both of these are out-of-date and error-ridden. Revisionary studies on specific groups of ants, carried out within the last 60 years and usually at a continent-wide scale, have had a more salutary effect on our knowledge of the California ant fauna. This includes taxonomic contributions by Bolton (1979), Brown (1950d, 1953g), Buren (1968b), Cole (1968), Creighton (1950a), Francoeur (1973), Gregg (1959, 1969b), Mackay (2000), Snelling (1970, 1973c, 1976, 1982a, 1982b, 1988, 1995a), Trager (1984b, 1991), Ward (1985b, 1999), Watkins (1976, 1985), Wilson (1955a, 2003) and Wing (1968a). Among the more useful publications for those seeking information about the ants of California are the regional treatments of the ants of Deep Canyon, Riverside County (Wheeler \& Wheeler 1973e), the California deserts 

on the ants of California is in preparation by Roy R. Snelling (pers. comm.).

\section{MATERIALS AND METHODS}

There are three principal parts to this paper: (1) a statement and justification of taxonomic changes, (2) a key to the ant genera of California, followed by a brief synopsis of each genus, and (3) a species list (Appendix). Taxa are arranged alphabetically by subfamily, genus and species, following the classification of Bolton (2003). Under the synopsis of California ant genera I have cited literature sources that may be useful for identification of species, as well as papers on general biology. Additional assistance with identification can be obtained by comparing the images of individual species on AntWeb.

The following abbreviations are used for museum collections (following Arnett et al. 1993 as far as possible):

CASC California Academy of Sciences, San Francisco, CA, USA

CDAE California Department of Food and Agriculture, Sacramento, CA, USA

LACM Natural History Museum of Los Angeles County, CA, USA

MCSN Museo Civico de Storia Naturale, Genoa, Italy

MCZC Museum of Comparative Zoology, Harvard University, Cambridge, MA, USA

MHNG Muséum d'Histoire Naturelle, Geneva, Switzerland

RAJC Robert A. Johnson Collection, Tempe, AZ, USA

UCDC Bohart Museum of Entomology, University of California, Davis, CA, USA

USNM National Museum of Natural History, Smithsonian Institution, Washington, DC, USA

WPMC William P. Mackay Collection, University of Texas at El Paso, TX, USA

The following worker measurements (in $\mathrm{mm}$ ) and indices are cited. The first four are taken with the head in full-face (dorsal) view.

HW Head width: maximum measurable head width. This excludes the compound eyes except in two genera of large-eyed ants where, by convention, the eyes are included: Pseudomyrmex (after Kempf 1960a) and Formica (after Francoeur 1973).

HL Head length: measured along the midline from the anterior clypeal margin to the midpoint of a line drawn across the posterior margin of the head.

EL Eye length: length of the compound eye, measured in the same plane as HL.

FCD Frontal carinal distance: maximum distance between the frontal carinae.

SL Scape length: chord length of the scape, excluding the basal condyle and neck.

PW Pronotum width: maximum width of the pronotum in dorsal view. 
FL Profemur length: length of the profemur, measured along its long axis in posterior view.

LHT Length of the hind tibia, measured in dorsolateral view, from the articulation with the femur, excluding the medioproximal condyle, to the distal extremity of the tibia.

DPW Dorsal petiolar width: maximum width of the petiole in dorsal view.

PPW Postpetiolar width: maximum width of the postpetiole (third abdominal segment) in dorsal view.

T4W Maximum width of the fourth abdominal tergite in dorsal view.

CI Cephalic index: HW/HL

REL Relative eye length: EL/HL

SI Scape index: SL/HW

No new taxa are described in this paper, except that a previously unavailable name in Camponotus is made available. Instead, most unidentifiable species are assigned code numbers (e.g., Hypoponera sp. CA-01), following the example set by the guide to Japanese ants (Morisita et al. 1989, 1991, 1992). For forms that are close to a named taxon but whose specific distinctness remains uncertain, I have used the expression "sp. cf.". Thus, "Paratrechina sp. cf. terricola" refers to a species that is either closely related to, or conspecific with, Paratrechina terricola (Buckley). The taxonomic quandaries raised here will hopefully stimulate more detailed systematic investigations. Since most of the ant species listed here are not confined to California, future monographic work will be most useful if it has a broader geographical scope than California alone.

\section{GENERAL FEATURES OF THE CALIFORNIA ANT FAUNA}

The ant fauna of California comprises approximately 281 species, representing nine subfamilies, 23 tribes and 44 genera (classification after Bolton 2003). Of this total, 22 species are clearly non-native, and most of these are of Old World origin. The status of four other species (Dorymyrmex flavus McCook, Hypoponera opaciceps (Mayr), Lasius neoniger Emery and Paratrechina vividula (Nylander)) is unclear: the distributions of these species within California and their associations with disturbed habitats suggest that they are introduced to the state, while native to other parts of the New World. Among the 255 indisputably indigenous species, $39(15.3 \%)$ are known only from California and a further 28 species extend only slightly beyond the state's borders to southern Oregon and/or northern Baja California. About 63 (24.7\%) of the indigenous ant species recorded from the state are endemic to the California floristic province, as defined by Hickman (1993).

This high level of endemism, comparable to that shown by California plants (Hickman 1993), can be contrasted with the situation in neighboring Arizona where ant species richness is greater ( 288 native species) but the level of endemism is lower (8.3\%) (Table 1). 
The harsh Mediterranean climate of California presumably makes it a less favorable environment for ants than regions that experience significant summer rainfall. This factor was cited by Wheeler (1917a: 459) to explain the relative poverty of montane ant communities in California compared to other western states. Geographic barriers also ring much of the state, adding to the insular aspect of the region (Bakker 1984). Climatic and geographic filters have thus produced a California ant fauna with a distinctive composition compared to other southwestern states, not richer in species but having a higher level of endemism.

There is also a greater proportion of exotic species (Table 1), but the introduced taxa are largely confined to disturbed sites at low elevations. As a result, most natural habitats in California are free of non-native ant species. Locations that provide good access to water in the summer (e.g., riparian habitats and artificially irrigated landscapes) are most susceptible to invasion by exotic ants.

TABLE 1. Ant species richness in California and other southwestern states. Endemism estimates for Arizona are approximate. The Texas list (O'Keefe et al. 2000) has been corrected for obvious errors.

\begin{tabular}{lcccccc}
\hline State & $\begin{array}{c}\text { Area } \\
\left(\mathrm{km}^{2}\right)\end{array}$ & $\begin{array}{c}\text { \# species (\# } \\
\text { native spp.) }\end{array}$ & $\begin{array}{c}\text { \# introduced } \\
\text { spp. }(\%)\end{array}$ & $\begin{array}{c}\text { \# endemic } \\
\text { spp. }(\%)\end{array}$ & $\begin{array}{c}\text { \% endemic } \\
(\text { of native spp.) }\end{array}$ & Data source \\
\hline California & 410,837 & $281(255)$ & $26(9.3)$ & $39(13.9)$ & 15.3 & Present study \\
Arizona & 294,897 & $300(288)$ & $11(3.7)$ & $24(8.0)$ & 8.3 & Cover \& Johnson (unpubl.) \\
New Mexico & 314,979 & $237(233)$ & $4(1.7)$ & $7(3.0)$ & 3.0 & Mackay \& Mackay (2002) \\
Texas & 692,109 & $267(251)$ & $16(6.0)$ & $10(3.7)$ & 4.0 & O'Keefe et al. (2000) \\
\hline
\end{tabular}

The numbers in Table 1 should be treated as provisional. Further collecting and taxonomic study of ants from California and adjacent regions will undoubtedly lead to the discovery of additional species. In particular, the species totals for New Mexico and Texas can be expected to increase substantially and eventually exceed those of California, although the ranking of levels of endemism is less likely to change. Within California the northeast corner of the state (Modoc Plateau) has not been well collected and additional ant species, of Great Basin distribution, will almost certainly be found there.

\section{TAXONOMIC CHANGES}

The preparation of a species list of California ants highlights the necessity of certain taxonomic changes, primarily involving new synonymy. These changes are formally documented and justified below. The expression "stat. nov." signifies a change to a new rank and "stat. rev." indicates a revision in rank to one used previously; "stat. reval." refers to names whose status changes from invalid to valid. 


\section{Genus Forelius Mayr}

In a recent taxonomic revision of this genus Cuezzo (2000) recognizes three species from the Nearctic region: F. mccooki (McCook 1880), F. pruinosus (Roger 1863a) and F. analis (André 1893b), with the last-named being removed from synonymy under $F$. pruinosus. All three species are recorded by Cuezzo (2000) from California. F. mccooki can be recognized by its abundant standing pilosity, but $F$. pruinosus and $F$. analis cannot be reliably distinguished using the differences cited by Cuezzo (2000). In Cuezzo's worker key $F$. analis is separated from $F$. pruinosus based on the shape of the posterior margin of the head: concave ("sometimes...weak") in F. analis, and straight in F. pruinosus. Yet, this putative difference is contradicted by Cuezzo's description of the F. analis worker-where the posterior margin is said to vary from convex to weakly concave-and by the illustration of a F. analis worker (Cuezzo 2000, figure 10) which shows a posterior margin that is convex. (F. pruinosus is described, and illustrated, as having the posterior margin of the head straight.) After examining a large series of Forelius from the United States and northern Mexico I can find no consistent difference in worker head shape: the posterior margin of the head varies continuously from weakly convex through straight to weakly concave. Color is also variable, ranging from dark brown to yellowish-orange. Some nest series contain both light and dark-colored workers. It is possible that the California populations are not conspecific with $F$. pruinosus (described from Cuba), but these and other western samples seem to grade insensibly into material from farther east and south, including populations in Florida and the West Indies with consistently dark and densely pubescent workers, which correspond to $F$. pruinosus (s.s.). The complex needs further study but because reliable diagnostic differences have not yet been uncovered I treat $F$. analis (type locality Chihuahua, Mexico) as a junior synonym of $F$. pruinosus (syn. nov.), thus returning to the conventional treatment of these two names.

It should be noted that even the distinction between $F$. mccooki (standing hairs present on scapes, posterior margin of head, and external face of tibiae) and $F$. pruinosus (standing hairs absent or very sparse on the afore-mentioned structures) occasionally breaks down in western North America, with workers from some localities showing intermediate amounts of pilosity. There is, however, a third distinct (and apparently undescribed) species of Forelius in the United States. It is small and dark with a conspicuously shiny mesepisternum, short scapes (SL 0.40-0.48), and sparse standing pilosity. This species ranges from southern Texas to Colombia, and has been found sympatrically with a larger Forelius species-apparently F. pruinosus_in Mexico, Guatemala and Costa Rica, without showing any sign of intergradation.

As a nomenclatural side note, the author of Forelius mccooki is McCook not Forel, since McCook's 1880 paper provides in his own words a sufficient "description or definition" (ICZN, Article 12) of the ants to make the name available, prior to Forel's (1886b) 
more detailed description of the same material. In addition, the date of publication of McCook's paper is 1880 (Ward et al. 1996: 275), not 1879 as cited by Bolton (1995b) and others. Cuezzo's (2000) attribution of authorship of F. mccooki to Forel is incorrect, but her designation of a lectotype from among material in the Forel collection in MHNG may be considered justifiable, to the extent that Forel's specimens came from McCook and were part of the material to which McCook referred in his 1880 paper.

\section{Subfamily Formicinae}

\section{Genus Camponotus Mayr}

\section{Camponotus maritimus Ward, sp. nov.}

(Figures 1-4)

Camponotus maculatus subsp. vicinus var. maritimus Wheeler 1910g: 305. Unavailable name.

Camponotus vicinus; Creighton 1950a, nec Mayr [in part].

Camponotus vicinus; Snelling 1970, nec Mayr [in part].

Camponotus sp. near vicinus; Wetterer et al. 2000.

Camponotus cf. vicinus; Sanders et al. 2001.

Camponotus sp. near vicinus; Ward 2005.

Holotype worker, Jasper Ridge, San Mateo Co., California, U.S.A., 150m, 37 $24^{\prime} \mathrm{N}$ $122^{\circ} 14^{\prime} \mathrm{W}, 3 . i v .2004$, under stone, oak woodland, P.S.Ward\#15202 [MCZC]. Paratypes: series of workers, queens and males, same data and nest series as holotype [BMNH, CASC, CDAE, LACM, MCZC, UCDC, USNM, WPMC].

Description, major worker. Medium-sized species, related to C. vicinus Mayr, but smaller on average and with a shinier appearance. Masticatory margin of mandibles with five teeth, the first four (counting from apex) acute, the proximal tooth truncate or weakly bifid, and subtended by a small tooth on the outer basal margin of mandible (dentition simpler-five acute teeth only-in smaller workers). Head as long as, or longer than, wide; sides of head weakly convex, diverging posteriorly, and rounding into concave posterior margin (in smaller workers sides of head subparallel and posterior margin convex). Eye about one-quarter of head length and not protruding from side of head in full-face view (breaking outline of head in smallest workers). Anterior clypeal margin crenulate, broadly convex in outline; median clypeal carina prominently developed. Scape relatively short (Figure 3); scape base subcylindrical, not strongly flattened or flared. Frontal carinae separated anteriorly by about one-fifth head width, flaring out posteriorly to about one-third of head width. Mesosoma dorsum convex in profile; dorsal face of propodeum longer than, and rounding into, declivitous face; propodeum markedly compressed from side to side. Petiole simple, scale-like in profile, with blunt summit, and convex in posterior view. Legs relatively short (Figure 4); in largest workers (HW 2.50-3.10 mm), LHT not exceed- 
ing $3.00 \mathrm{~mm}$. Body subopaque to sublucid, with a distinctly greater sheen than in workers of $C$. vicinus. Sculpture consisting of fine reticulations, with scattered punctures, coarser on head than on abdominal tergites. Pilosity moderately common on most of body, finetipped and golden-yellow; standing pilosity absent from scapes (except apices), external face of tibiae, and sides of head, present on clypeus, midline of head, venter of head, mesosoma, petiole and rest of metasoma. The following numbers of standing setae present on the indicated structures (counts include all sizes of workers): profemur 3-13, pronotum 220, mesonotum 2-13, propodeum 3-10, petiole 5-11, abdominal tergite III (exclusive of posterior margin) 4-21, abdominal tergite III posterior margin 5-15, abdominal tergite IV (exclusive of posterior margin) 5-24, abdominal tergite III posterior margin 8-28. Fine, appressed pubescence present on most of body but not forming a dense mat; appressed hairs on abdominal tergites 3 and 4 (gastric tergites 1 and 2) relatively short and sparse and separated by about their lengths. Medium to dark brown, head and metasoma darker, legs, antennal segments 2-12, and scape base usually lighter.

Worker measurements $(\mathrm{n}=30)$. HW 1.08-3.11, HL 1.44-3.17, SL 1.59-2.68, PW 0.93-1.97, LHT 1.78-3.01, CI 0.73-1.00, SI 0.79-1.54, REL 0.21-0.31, LHT/HW 0.941.71.

DNA sequence data. The following GenBank sequences are available for Camponotus maritimus: 18S ribosomal RNA gene (AY867448), 28S ribosomal RNA gene (AY867464), wingless (AY867433), long wavelength rhodopsin (AY867495) and abdominal-A (AY867480). All sequences derive from a single worker taken from the same nest series as the holotype.

Comments. Wheeler's maritimus has remained a quadrinomen, and hence unavailable, since the original description. Creighton (1950a) considered it to represent a synonym of the more widespread species Camponotus vicinus, but there are in fact two distinct sympatric species in California. Workers of what is here called C. maritimus can be distinguished from those of $C$. vicinus by the narrower scape base, shorter scape, shorter legs, more closely adjacent frontal carinae, shinier integument, and sparser pubescence on abdominal tergites 3 and 4 (appressed hairs separated by about their lengths in $C$. maritimus, by less than their lengths in $C$. vicinus). Plots of SL by HW and LHT by HW separate all but the smallest workers of $C$. maritimus and $C$. vicinus (Figures 3-4), except in southern coastal California. In this latter region there are vicinus-like populations in chaparral and coastal sage scrub with atypically short scapes and legs. The workers of these populations can be separated from those of $C$. maritimus by the other characters, especially the duller integument of the head and abdominal tergites 3 and 4 , and the denser pubescence on the latter. In addition workers of the southern coastal populations of vicinus are exceptionally hairy, with standing pilosity commonly present on the sides of the head, as seen in full-face view, and on the venter of the metafemur (standing pilosity generally absent on these structures in C. maritimus).

C. maritimus occurs in coastal regions of California from Mendocino and Lake Coun- 
ties to San Diego County (including the Channel Islands), and in the western foothills of the Sierra Nevada. Habitats from which it has been collected include chaparral, serpentine chaparral, serpentine grassland, oak woodland, mixed redwood forest, coniferous forest on serpentine, and coastal scrub. Colonies are most frequently found under stones, less commonly in or under rotten wood.
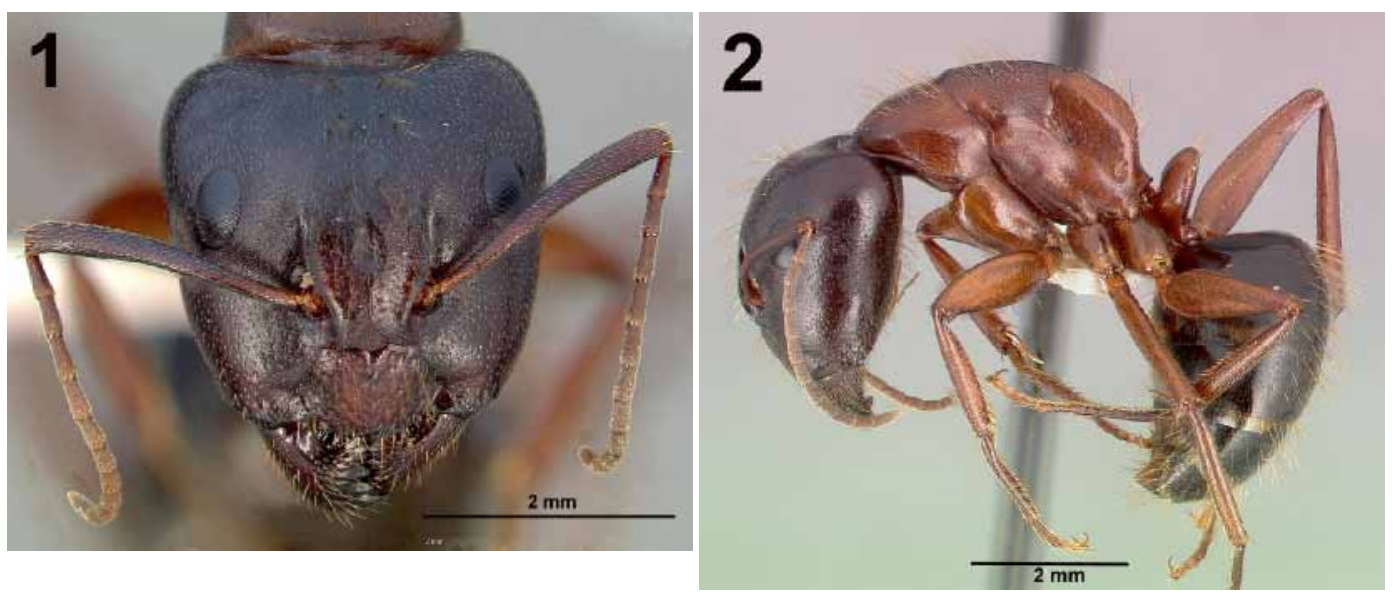

FIGURES 1-2. Camponotus maritimus holotype worker. 1, full-face view of head; 2, lateral view of body.

3

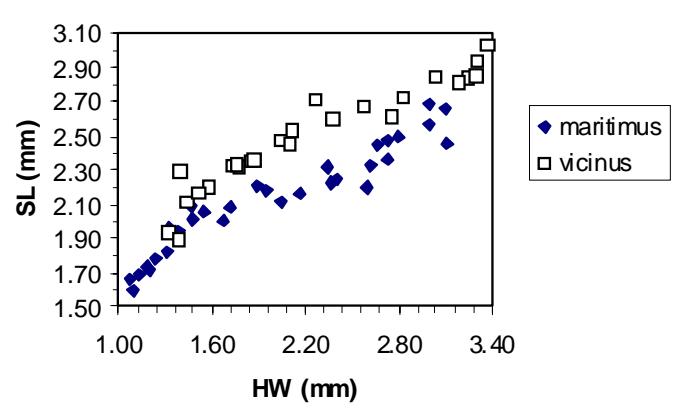

4

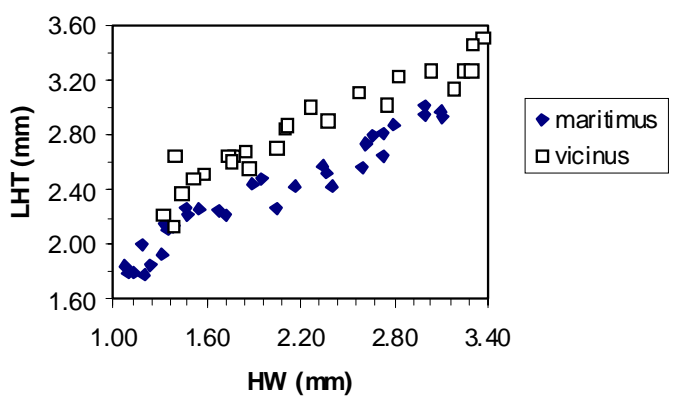

FIGURES 3-4. Bivariate plots of SL and LHT by HW, for workers of Camponotus maritimus and C. vicinus.

Localities cited by Wheeler (1910g: 305) in his description of Camponotus maculatus subsp. vicinus var. maritimus are Pacific Grove and San José (H. Heath) and Catalina Island (C. F. Baker). Old specimens collected by Baker, Heath and Wheeler, and placed by Wheeler under "maritimus" in the MCZ collection, belong to three species: $C$. maritimus (from Catalina Island and Palo Alto), C. semitestaceus Snelling (Palo Alto) and $C$. vicinus Mayr (Pacific Grove). Some of these specimens are labeled as maritimus "types" but none of them has true type status because maritimus Wheeler is an unavailable name. 
For convenience I have chosen the holotype and paratypes of $C$. maritimus Ward from a nest series collected recently at Jasper Ridge near Palo Alto, rather than from the old specimens. Wheeler, it seems, correctly inferred the presence of more than one species but he did not distinguish them with $100 \%$ accuracy.

\section{Genus Lasius Fabricius}

A close relationship between Acanthomyops Mayr and Lasius has long been recognized (Creighton 1950a, Wilson 1955a, Wing 1968a). Recent molecular studies (Savolainen 2002, Janda et al. 2004) demonstrate that Acanthomyops is nested phylogenetically within Lasius. To maintain monophyly for Lasius, Acanthomyops cannot be treated as a separate genus. It is here returned to the status of subgenus (stat. rev.) in Lasius, which generates revised or new combinations in Lasius for the following species names: arizonicus comb. rev., bureni comb. nov., californicus comb. rev., claviger comb. rev., clavigeroides comb. rev., colei comb. nov., coloradensis comb. rev., creightoni comb. nov., interjectus comb. rev., latipes comb. rev., mexicanus comb. rev., murphyi comb. rev., occidentalis comb. rev., parvula comb. rev., plumopilosus comb. rev., pogonogynus comb. rev., pubescens comb. rev., and subglaber comb. rev.

\section{Subfamily Myrmicinae}

\section{Genus Leptothorax Mayr}

The ant genus Leptothorax formerly comprised a large and heterogeneous assemblage of species but Bolton (2003) redefined it to include only those species closely related to $L$. acervorum Fabricius. Most California species previously placed in Leptothorax are now assigned to Temnothorax Mayr (see below), with two species remaining in Leptothorax.

Leptothorax calderoni Creighton 1950a stat. reval., stat. nov. (Figure 5)

Leptothorax (Mychothorax) acervorum race canadensis var. calderoni Forel 1914c: 617. [Unavailable name.]

Leptothorax (Mychothorax) canadensis calderoni Creighton 1950a: 276. [First available use of name.] Three syntype workers, one syntype alate queen, Lake Tahoe, California, 6325' (Calderon) $[\mathrm{MHNG}][$ Examined]

Comments. Leptothorax calderoni is a large, bicolored species with short standing pilosity and a robust petiole. In California it is sympatric with another species in the L. mus- 
corum-complex, here called Leptothorax sp. CA-01 (this second species might correspond to L. canadensis Provancher). In contrast to Leptothorax sp. CA-01, the petiole of L. calderoni has a less peaked appearance, with the anterior and dorsal faces forming a right angle in lateral view. The two pairs of standing hairs visible in profile on the dorsum of the petiole are separated by notably more than their lengths, whereas in $L$. sp. CA-01 they are separated by about their lengths or less (compare Figures 5 and 6). In addition, L. calderoni is larger (worker HW $0.66-0.81 ; \mathrm{n}=35$ ) with disproportionately longer legs (worker FL $0.56-0.66 ; \mathrm{n}=35$ ) compared to $L$. sp. CA-01 (worker HW 0.56-0.70, worker FL $0.44-0.56 ; \mathrm{n}=70$ ). The mesosoma, petiole and postpetiole of $L$. calderoni are orangebrown, the head medium brown and gaster dark brown. Color contrasts tend to be less marked in $L$. sp. CA-01.

Most records of $L$. calderoni come from coniferous forest at moderate to high elevations in the Sierra Nevada of California (1470-2680 m), with outlier populations in the northern Coast Ranges and in the San Bernardino Mountains of southern California. Colonies are found in cavities in hard, dead wood. Workers are often conspicuous as foragers on downed logs.

Bolton (1995b) incorrectly listed L. calderoni as an unavailable name, overlooking that fact that Creighton's (1950a) treatment of it as a trinomen rendered it available. Creighton considered L. calderoni to be a subspecies of $L$. canadensis and a senior synonym of L. canadensis septentrionalis Wheeler (1917a). Actually L. c. septentrionalis would have seniority if the two were synonyms, but they are not conspecific. They have a similar color pattern but L. c. septentrionalis (described from Banff, Alberta and Emerald Lake, British Columbia) has longer setae, a more peaked petiole, and is smaller in size (syntype workers in MCZC examined).

\section{Genus Monomorium Mayr}

Leaving aside introduced species, the Nearctic Monomorium belong to the taxonomically vexing minimum-group, revised by DuBois in 1986. Several of the species recognized by DuBois (1986) are problematic, and parts of his keys to workers and queens are unusable. Here I deal only with the two taxa recorded from California: $M$. wheelerorum DuBois is considered to be a junior synomym of $M$. ergatogyna Wheeler (syn. nov.) because the putative differences between the two "species" cannot be verified. A key distinguishing feature is said to be the lateral profile of the scutum and scutellum of the queen: flat or slightly depressed in $M$. wheelerorum and convex in M. ergatogyna. In populations from northern California, however, this character shows continuous variation between these two conditions, even among queens from the same nest (the species is polygynous). Other supposed queen and worker differences disappear when intra- and interpopulation variation are taken into account. A modern systematic treatment of the M. minimum-group is badly needed. Because the queens are apterous in most western populations, interpopula- 
tion differentiation is expected to be accentuated, a factor that needs to be considered in any taxonomic study.

\section{Genus Myrmica Jurine}

The Nearctic species of this genus are currently being revised by André Francoeur (pers. comm.). In accordance with his findings Myrmica glacialis Emery is here treated as a valid species (stat. reval., stat. nov.). It was previously considered a synonym of M. lobifrons Pergande.

\section{Genus Temnothorax Mayr}

A recent comprehensive reorganization of the tribe Formicoxenini by Bolton (2003) led to the division of Leptothorax (sensu lato) into three genera: Leptothorax, Nesomyrmex Wheeler and Temnothorax, of which the first and last are represented in California. Temnothorax includes species previously placed in the subgenus Myrafant M. Smith. A revision of the New World Myrafant species by Mackay (2000) helped to improve the alphataxonomy of the group but various problems remain, particularly among the California species. In preparing a checklist of the ant fauna of this state it became necessary to tackle certain issues left unresolved by Mackay's revision.

There is a rich Temnothorax fauna in California, and in the adjacent Baja California peninsula (Johnson \& Ward 2002). At least ten undescribed species occur in California, here indicated by code numbers (Temnothorax sp. CA-01 to CA-10). These are the subject of ongoing taxonomic study by Roy Snelling (LACM). In this paper I confine myself to clarifying the nomenclature and species limits of some of the described taxa.

\section{Temnothorax andrei (Emery 1895d)}

(Figure 7)

Leptothorax andrei Emery 1895d: 322. Holotype worker, Martinez, California (Turner) [MCSN] [Examined]

Leptothorax nitens var. Heathii Wheeler 1903d: 245. Twelve syntype workers, Pacific Grove, California [MCZC] [Examined] Syn. nov. [Incorrectly synonymized under nitens by Creighton 1950a: 265.]

Leptothorax nitens subsp. occidentalis Wheeler 1903d: 245. Two syntype workers, Friday Harbor, Washington [MCZC] [Examined] Syn. nov. [Incorrectly synonymized under nitens by Creighton 1950a: 265.]

Leptothorax ocellatus Mackay 2000: 383. Holotype worker, 5 mi W Mineral, Tehama Co., California, 4250' (D. Chandler) [MCZC] [Examined] Syn. nov.

Temnothorax andrei (Emery); Bolton 2003: 271. First combination in Temnothorax.

Temnothorax ocellatus (Mackay); Bolton 2003: 272. First combination in Temnothorax. 

$1800 \mathrm{~m}$ ) in California and adjacent western states. The workers are yellow to yellowbrown, lightly sculptured, and with relatively short, blunt-tipped pilosity. The head is predominantly longitudinally reticulate/carinulate with weakly shining interspaces, and with a smooth, shiny median strip of variable extent. A characteristic feature is the presence of a small, isolated shiny patch of cuticle on the head, posteromesad of the compound eye, and surrounded by sculpture. The mesosoma is reticulate-foveolate and subopaque. The propodeal spines are poorly developed and generally reduced to blunt triangular teeth. In profile the petiolar node, while slender, has an abruptly rounded (not cuneate) summit (Fig. 7). During a recent visit to MCSN (Genoa) Alex Wild matched the holotype worker of $T$. andrei to material from California that I had identified as this species. The unique type of T. ocellatus falls easily within the range of variation encompassed by $T$. andrei. The original description of $T$. ocellatus misrepresents some features of its morphology. The mesosoma is not as strongly arched as depicted and, although the eyes are small, they are not atypically so for $T$. andrei.

In coastal regions of central and northern California populations of T. andrei tend to produce workers that are darker in color, with a shinier head and better developed propodeal spines. While some samples appear strikingly different from the more typical light-colored T. andrei, it is difficult to draw a sharp boundary between the coastal and inland populations because of extensive intra- and interpopulation variation. The type series of T. nitens heathii (from Pacific Grove) exemplifies this, with some workers having predominantly smooth and shiny heads and others showing varying amounts of fine reticulate/carinulate sculpture. The syntype workers of T. nitens occidentalis (from coastal Washington state) also have variably shiny heads. For both heathii and occidentalis, however, the rounded (non-cuneate) summit of the worker petiole clearly identifies them as being related to $T$. andrei rather than T. nitens. A failure by previous investigators to examine critically the types of heathii or occidentalis led to their being erroneously associated with T. nitens.

\section{Temnothorax nevadensis (Wheeler 1903d)}

(Figure 9)

Leptothorax nevadensis Wheeler 1903d: 252. Two syntype workers, two syntype males, Kings Cañon, Ormsby Co., Nevada (C. F. Baker) [MCZC] [Examined] Note: original description also includes dealate queen.

Leptothorax melanderi Wheeler 1909e: 81. Holotype worker, Moscow Mountain, Idaho (A. L. Melander) [AMNH] [Not examined]. Synonymy by Mackay 2000: 376.

Leptothorax eldoradensis Wheeler 1915b: 414. Two syntype workers, Mt. Wilson, California (J. C. Bradley) [MCZC] [Examined]. Synonymy by Mackay 2000: 376; here confirmed.

Leptothorax lindae Mackay 2000: 356. Holotype worker, Wolverton Campground, Sequoia Natl. Park, Tulare Co., California (W. \& L. Mackay) [MCZC] [Examined]. Paratype workers (same 
data) in LACM also examined. Syn. nov.

Leptothorax maryanae Mackay 2000: 364. Holotype worker, 4 mi N Fawnskin, San Bernardino

Mnts, California (B. \& E. Mackay) [MCZC] [Examined] Syn. nov.

Temnothorax lindae (Mackay); Bolton 2003: 271. First combination in Temnothorax.

Temnothorax maryanae (Mackay); Bolton 2003: 271. First combination in Temnothorax.

Temnothorax nevadensis (Wheeler); Bolton 2003: 271. First combination in Temnothorax.

Comments. This is another common species of Temnothorax in California and other western states, occupying a broad range of habitats, including coastal scrub, chaparral, oak woodland, open coniferous forest, and sagebrush desert. The worker can be recognized by the dark brown to black body color; relatively long and slender pilosity; opaque to sublucid head, with longitudinal rugoreticulate sculpture and scattered foveolae; dense foveolate sculpture on the mesosoma, overlain by weak rugulae; well developed propodeal spines; slender petiole, with anterior face rounding abruptly into posterodorsal face (Fig. 9); and relatively narrow postpetiole (PPW/DPW 1.34-1.51, PPW/T4W 0.33-0.39; $n=6$ ). Size is variable, such that worker HW $0.47-0.70$, but usually $>0.55$. There is considerable variation in the length and slenderness of the propodeal spines but they are always longer than the anteroventral petiolar process. In some T. nevadensis workers from eastern California and Nevada the head is rather shiny (sculpture much reduced), but the variation appears to be continuous. Interestingly, a similar trend is seen in the related arboreal species, T. gallae (M. R. Smith): near its eastern limit (in Joshua Tree National Park, southeastern California) workers have shinier heads than in populations farther west.

Taking into account the variability inherent in T. nevadensis, this species readily encompasses the forms described by Mackay (2000) as T. lindae and T. maryanae (and placed inexplicably by him in different species complexes, separate from one another and from T. nevadensis), plus two of the three taxa previously considered to be subspecies of $T$. nevadensis: melanderi and eldoradensis. I have not examined the type of T. melanderi so some doubt remains here, but the original description and the type locality suggest that the synonymy is justified. On the other hand, T. rudis, described as a subspecies of $T$. nevadensis—and synonymized under T. nevadensis by Mackay (2000)—is a distinct and easily recognized species, as documented below.

\section{Temnothorax nitens (Emery, 1895d)}

(Figure 8)

Leptothorax nitens Emery 1895d: 322. Holotype worker, American Fork Canon, Utah [USNM] [Examined]

Leptothorax nitens var. mariposa Wheeler 1917a: 507. Nine syntype workers, Camp Curry, Yosemite, California [LACM, MCZC] [Examined] Syn. nov.

Leptothorax mariposa Wheeler; Cole 1958c: 536. Raised to species.

Leptothorax melinus Mackay 2000: 368. Holotype worker, Beartrap Cyn., Socorro Co., New Mexico, 2286 m (W. Mackay \#16889) [MCZC] [Examined]. Two paratype workers in LACM 
Temnothorax mariposa (Wheeler); Bolton 2003: 271. First combination in Temnothorax. Temnothorax melinus (Mackay); Bolton 2003: 271. First combination in Temnothorax. Temnothorax nitens (Emery); Bolton 2003: 271. First combination in Temnothorax.

Comments. T. nitens is a common western United States species characterized by a strongly cuneate (wedge-shaped) petiole, as seen in profile (Fig. 8). Body color varies from pale yellow to medium brown. Integument sculpture tends to be light; the head and mesosoma are finely reticulate-foveolate, with extensive shiny areas usually on the front of the head and occasionally on the mesosoma dorsum. The propodeal spines are variable, relatively short but better developed (on average) than in $T$. andrei, and usually as prominent as the anteroventral petiolar process, or more so (Figure 8). In the holotype worker of T. nitens the mesosoma dorsum is smooth and shiny centrally, but as noted by others (Wheeler 1903d; Cole 1958c) the head and mesosomal sculpture is highly variable in this species, and both shiny and more heavily sculptured workers can be found in the same nest. I have also observed this in California populations from the Sierra Nevada. The California workers with a shiny promesonotum tend to have weak longitudinal carinulae encroaching anteriorly and laterally, as in the T. nitens type.

Mackay's (2000) treatment of T. nitens is inconsistent. On the one hand he seems to accept a broad concept of the species, showing it as having a wide distribution in western North America, accepting the previous synonymy of heathii and occidentalis under $T$. nitens (incorrectly, as it turns out-see under T. andrei), and citing biological data from a diverse selection of localities. On the other hand, he describes a colony series from New Mexico as a new species (melinus), even though it falls well within the ambit of T. nitens (sensu lato). Restricting the use of the name $T$. nitens to workers with an especially shiny mesosoma is difficult to justify, given the patterns of intranidal variation described above. It seems more reasonable to treat it as a polytypic species, with variable effacement of the mesosomal sculpture.

T. mariposa was originally described as a variety of $T$. nitens. It was synonymized under that species by Creighton (1950a), and later resurrected by Cole (1958c) and raised to species. Cole's argument was that both forms co-occurred in the Yosemite region without intergrading. But examination of a large series of nitens-like specimens from throughout the California Sierra Nevada challenges this thesis. It leads me to the conclusion that T. mariposa simply connotes larger individuals of T. nitens which have correspondingly broader heads and a tendency towards darker body color and coarser sculpture on the side of the mesosoma. There is no evidence of a gap in this size variation (nor in the correlated variation in shape, color and sculpture). The LACM collection has nitens-like nest series collected by Cole at Yosemite. His accessions 136, 184, 198, 201, 230, 231 and 233 are identified as "nitens" and 239 as "mariposa". The "nitens" series are collectively smaller and more lightly sculptured than accession 239, but accessions 230, 231 and 233 have workers approaching those of 239 in size and sculpture. Moreover, the syntypes of $T$. 
mariposa (LACM, MCZC) agree more closely with the majority series (136 to 233) than with 239, so Cole's attributions and conclusions are difficult to justify.

Temnothorax chandleri (Mackay) is evidently closely related to L. nitens and might prove to be conspecific with it. The main diagnostic feature of $T$. chandleri is the heavily sculptured head, which lacks a shiny surface except for a median strip. The type series consisted of three workers, of which the holotype was destroyed while in transit to MCZC (Stefan Cover, pers. comm.). A paratype worker was said to be deposited at the University of New Hampshire (Mackay 2000: 331) but no specimen is present there (Don Chandler, pers. comm.). Thus, the only known type specimen is the paratype worker in WPMC. Here is a description of that specimen which I examined briefly in August 2003:

Petiole cuneate in profile; HW $\sim 0.57 \mathrm{~mm}$; head densely reticulate-foveolate (with weak longitudinal orientation), except for a small shiny central strip which does not extend to the posterior margin; mesosoma densely reticulate-foveolate; propodeal spines short, blunt; dorsum of mesosoma with about 24 short, erect hairs in profile; abdominal tergite IV smooth and shiny except for weak basal striolae; postpetiole moderately broad, length $\sim 0.7 \times$ width; pale yellow brown.

This paratype agrees with five workers collected recently at Black Butte Lake, Glenn Co., California (P. S. Ward\#14606), in a fallen log of cottonwood (Populus fremontii) in riparian woodland. The types of $T$. chandleri were collected from leaf litter at the edge of a slough (Mackay 2000). These limited biological data suggest that $T$. chandleri may be a riparian habitat specialist, whereas T. nitens is found in a diverse array of habitats from sea level to $\sim 2600 \mathrm{~m}$.

\section{Temnothorax rudis (Wheeler 1917a) stat. reval., comb. nov.}

(Figure 10)

Leptothorax nevadensis subsp. rudis Wheeler 1917a: 508. Six syntype workers, Camp Curry, Yosemite, California [MCZC] [Examined]. Note: original description also includes dealate queen, and cites the type locality as Tenaya Canyon, Yosemite Valley. Incorrectly synonymized under T. nevadensis by Mackay 2000: 376.

Leptothorax rudis Wheeler; Stuart and Page 1991: 375. Genetic study (rudis implicitly raised to species).

Comments. This is a distinct species that occurs sympatrically with T. nevadensis in many parts of northern and central California, without showing any sign of intergradation. $T$. rudis is readily distinguished from T. nevadensis by petiole shape. In T. rudis the petiole is broader in profile, with the anterior and posterodorsal faces meeting at approximately $90^{\circ}$, and the posterodorsal face declining gently (Fig. 10). In T. nevadensis the petiole is more slender in profile, with the anterior and posterodorsal faces forming an acute angle (Fig. 9). In addition T. rudis has coarser body sculpture and is lighter in color than T. nevadensis. T. rudis is common in mixed coniferous forests of California, up to about $1750 \mathrm{~m}$ ele- 
vation. Colonies can be found in rotten wood, under stones, in fallen acorns, and in the leaf litter.

Bolton (1995) stated that rudis Wheeler 1917a, then combined with Leptothorax, was a primary junior homonym of rudis Mayr 1868c. Mayr's species, a fossil taxon, was originally combined with Macromischa, however, and then later with Nothomyrmica (Wheeler 1915i), prior to Macromischa being subsumed under Leptothorax. Mayr's rudis was never treated as a species of Leptothorax, so no homonymy arises.
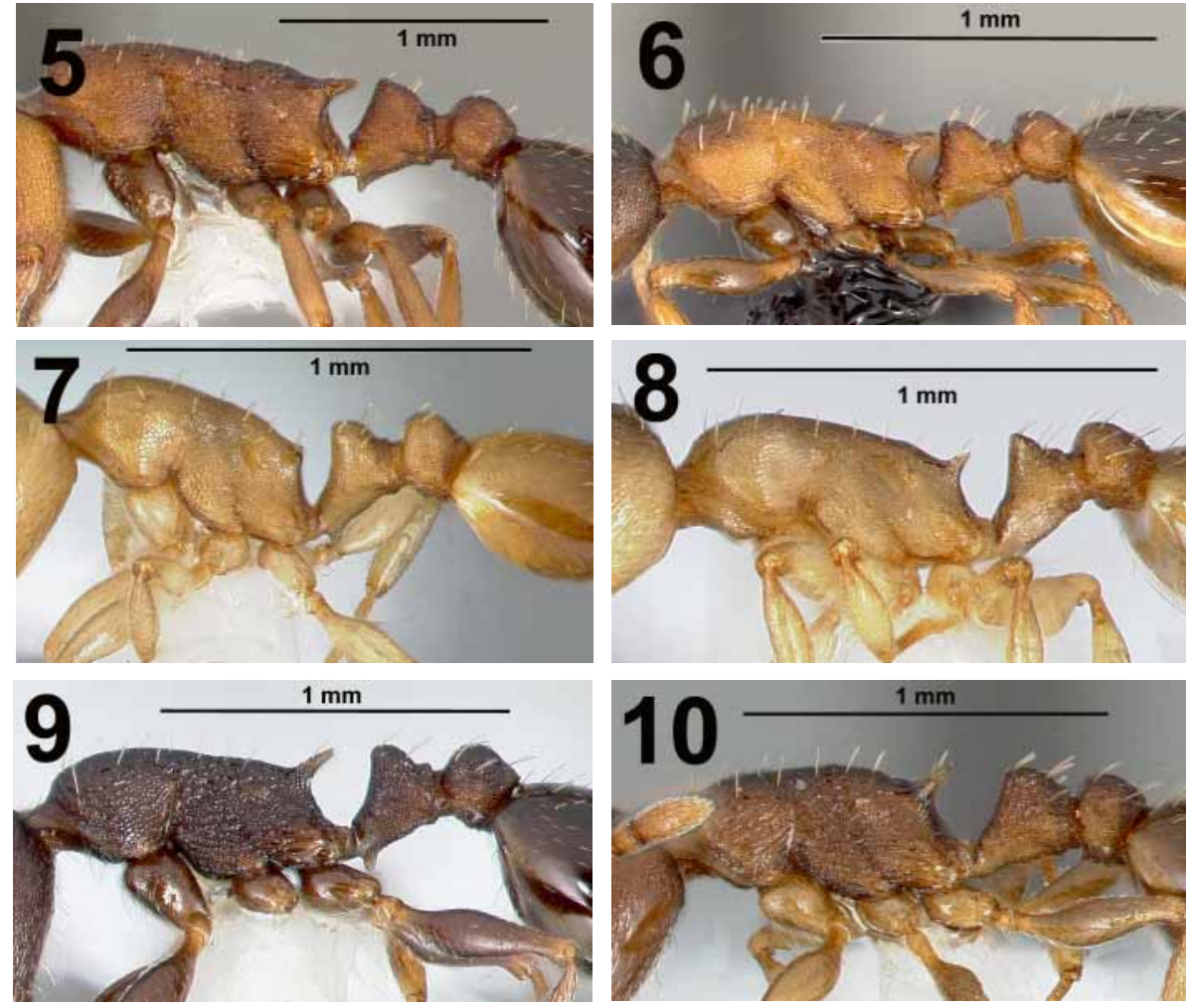

FIGURES 5-10. Leptothorax and Temnothorax workers, lateral views showing mesosoma, petiole and postpetiole. 5, Leptothorax calderoni; 6, Leptothorax sp. CA-01; 7, Temnothorax andrei; 8, T. nitens; 9, T. nevadensis; 10 , T. rudis.

\section{KEY TO CALIFORNIA ANT GENERA BASED ON THE WORKER CASTE}

Morphological terminology follows Bolton (1994), on which much of this key is based. The term mesosoma is used in preference to alitrunk, to refer to the body part formed from fusion of the thorax and the first abdominal segment (i.e., thorax + propodeum). The promesonotum is that part of the mesosoma composed of the pronotum and the mesonotum. Metasoma refers to the apparent abdomen, comprising the segments posterior to the 
propodeum, i.e., abdominal segment 2 and succeeding segments. In ants abdominal segment 2 forms a node- or scale-like petiole, which is separated by a constriction from the rest of the metasoma. In some species abdominal segment 3 is also node-like and in this case it is said to form a postpetiole.

The key has been designed to apply only to those ant species occurring in California but it should also work for most of western North America, excluding Arizona and New Mexico where additional genera occur.

1 Postpetiole present: abdominal segment 3 separated from segment 4 by a strong constriction and distinctly smaller in size, so that anteriorly the metasoma has two nodelike segments, the petiole and postpetiole

- Postpetiole absent: abdominal segment 3 separated from segment 4 by a weak to moderate constriction or by none at all, and when viewed in profile not distinctly smaller in size (height) than segment 4; metasoma anteriorly with a single, isolated node-like or scale-like segment 26

2 Eye reduced to a single ommatidium or absent; antennal insertions fully exposed in a full-face view of head (Ecitoninae) Neivamyrmex Borgmeier

- Eye very rarely reduced, usually consisting of multiple ommatidia; antennal insertions not fully exposed, covered partially by frontal lobes or medial extensions of the antennal sclerites, when the head is observed in full-face view

3 Eye very large, eye length about one-half of head length (excluding mandibles); pronotum freely articulating with mesonotum (Pseudomyrmecinae)

Pseudomyrmex Lund

- Eye less than one-half head length; pronotum fused with mesonotum (Myrmicinae) ...

4 Antenna with 6 segments, including a 2-segmented club . 4

- Antenna with 10 segments, including a 2-segmented club Solenopsis Westwood

- Antenna with 11 segments; club variable

- Antenna with 12 segments; club variable

5 Mandible elongate and linear, with an apical fork of two spiniform teeth

Strumigenys F. Smith

- Mandible short and subtriangular, with a multi-denticulate masticatory margin Pyramica Roger

6 Postpetiole attached to the dorsal surface of the following abdominal segment; petiole dorsoventrally flattened, not node-like in profile. Crematogaster Mayr

- Postpetiole attached to the anterior face of the following segment; petiole node-like in profile, not dorsoventrally flattened

7 Head in lateral view with a diagonal carina running from above the eye down toward the mandibular insertion; promesonotum with conspicuous tubercles or spines .......... 8

- Head in lateral view lacking such a diagonal carina; promesonotum without conspicu- 
8 Frontal lobes expanded laterally and covering the sides of the head below the eyes, in full-face view; body lacking erect pilosity Cyphomyrmex Mayr

- Frontal lobes not expanded laterally to cover the sides of the head; body with erect pilosity Acromyrmex Mayr

9 Antenna with a distinct 2-segmented apical club Wasmannia Forel

- Antenna lacking a distinct 2-segmented apical club, either 3-segmented or indistinct .. 10

10 Eyeabsent or rudimentary; propodeum unarmed, basal facerounding into declivitous face Solenopsidini new genus

- Eye well developed, with multiple ommatidia; propodeum angulate or spinose ....... 11

11 Lateral portions of clypeus, in front of the antennal insertions, developed in the form of a raised ridge or shield-wall; frontal carinae extending almost to the posterior margin of the head Tetramorium Mayr (part)

- Lateral portions of clypeus not developed as a raised ridge or shield-wall; frontal carinae very short or absent.

12 Eye with short erect setae projecting between the ommatidia ........Formicoxenus Mayr

- Eye lacking erect setae

13 Median portion of clypeus with a smooth, longitudinally excavate surface, and lacking carinae Leptothorax Mayr

- Median portion of clypeus with several longitudinal carinae

Temnothorax Mayr (part)

14 Hind tibial spur finely pectinate (as seen at 50-100× magnification) 15

- Hind tibial spur simple or absent.

15 Metanotal groove absent or very weakly impressed, not breaking the dorsal profile of the mesosoma; psammophore usually present Pogonomyrmex Mayr

- Metanotal groove present and interrupting the dorsal profile of the mesosoma; psammophore absent 16

16 Propodeum unarmed; mandible with more than 12 teeth ........................ Manica Jurine

- Propodeum armed with a pair of spines; mandible with 6-10 teeth .. Myrmica Latreille

17 Lateral portions of clypeus, in front of the antennal insertions, developed in the form of a raised ridge or shield-wall; apex of sting with triangular lamellate appendage Tetramorium Mayr (part)

- Lateral portions of clypeus not developed as a raised ridge or shield-wall; apex of sting without triangular lamellate appendage

18 Petiole short and sessile, lacking well differentiated anterior peduncle and dorsal node; ventrolateral margin of head with sharp, longitudinal carina extending from mandibular base to posterolateral corner of head Myrmecina Curtis

- Petiole with anterior peduncle and dorsal node; ventrolateral margin of head without sharp, longitudinal carina 
19 Dorsum of head and mesosoma without standing pilosity.......... Cardiocondyla Emery

- Dorsum of head and mesosoma with standing pilosity

20 Anteromedian portion of clypeus notably elevated and bounded by a pair of carinae that diverge anteriorly

- Anteromedian portion of clypeus not abruptly elevated and lacking a pair of anteriorly diverging carinae

21 Propodeum unarmed Monomorium Mayr

- Propodeum armed with a pair of teeth or spines 22

22 Antennal club 3-segmented; propodeal spiracle large and located close to the declivitous face of the propodeum, separated from latter by no more than the diameter of the spiracle Rogeria Emery

- Antennal club 4-segmented; propodeal spiracle relatively small and separated from the declivitous face of the propodeum by more than the spiracle diameter...

Stenamma Westwood

23 Antennal club 3- (rarely 4-) segmented. .24

- Antenna lacking a distinct club 25

24 In profile promesonotum domed and distinctly elevated above the propodeal dorsum; workers dimorphic Pheidole Westwood

- In profile entire mesosoma dorsum flat to weakly convex, promesonotum not domed or markedly elevated above the level of the propodeum; workers monomorphic

Temnothorax Mayr (part)

25 Head narrow, longer than broad; mandible slender and triangular, outer margin not strongly curving towards the midline; psammophore absent ...... Aphaenogaster Mayr

- Head broad, subquadrate; mandible short and thick, outer margin strongly curving towards the midline; psammophore usually present Messor Forel

26 Pygidium (last visible abdominal tergite) flattened and bordered laterally with a row of peg-like teeth or spines that converge distally (Cerapachyinae)....Cerapachys F. Smith

- Pygidium (last visible abdominal tergite) convex and rounded, lacking a row of teeth or spines

27 Distinct constriction between abdominal segments 3 and 4; terga and sterna of abdominal segments 3 and 4 laterally fused

- No constriction between abdominal segments 3 and 4; terga of abdominal segments 3 and 4 overlapping the corresponding sterna, not laterally fused with them

28 Articulation of petiole (second abdominal segment) to third abdominal segment very broad; petiole without a distinct posterior face (Amblyoponinae)

Amblyopone Erichson

- Articulation of petiole (second abdominal segment) to third abdominal segment narrow; petiole with a distinct posterior face

29 Pronotum freely articulating with the mesonotum; abdominal tergite 4 not strongly enlarged and not curved ventrally; apex of metasoma directed posteriorly (Ponerinae) 
- Pronotum fused immovably to the mesonotum; abdominal tergite 4 strongly enlarged and curved ventrally; apex of metasoma directed anteriorly (Proceratiinae).

Proceratium Roger

30 Apex of metasoma with a circular orifice, often fringed with short setae (the acidopore) (Formicinae). 31

- Apex of metasoma with a slit-shaped orifice (Dolichoderinae) 38

31 Antenna with 9 segments Brachymyrmex Mayr

- Antenna with 11 segments Plagiolepis Mayr

- Antenna with 12 segments 32

32 Metapleural gland absent; antennal insertions well separated from the posterior clypeal margin; in profile mesosoma dorsum usually evenly convex ... Camponotus Mayr

- Metapleural gland present; antennal insertions adjacent to the posterior clypeal margin; in profile promesonotum separated from the dorsal face of the propodeum by a distinct impression

33 Maxillary palp segments 3 and 4 greatly elongated, segment 3 (counting from base) half the head length or more; psammophore present Myrmecocystus Wesmael

- Maxillary palp segments 3 and 4 not greatly elongated, segment 3 much less than half the head length; psammophore absent

34 Ocelli present; propodeal spiracle elliptical to oval .35

- Ocelli absent or indistinct; propodeal spiracle circular to subcircular 36

35 Mandible triangular, with seven or more distinct teeth on the masticatory margin Formica Linnaeus

- Mandible falcate (sickle-shaped) and lacking distinct teeth Polyergus Latreille

36 Dorsum of head and mesosoma with coarse setae, arranged in distinct pairs; eye situated in relatively anterior position, at or in front of midlength of side of head

Paratrechina Motschoulsky

- Pilosity on dorsum of head and mesosoma variable, but not arranged as coarse setae in pairs; eye situated in relatively posterior position, behind midlength of side of head ...

37 Mandible with six teeth; antennal scape long, surpassing posterior margin of head by more than half its length; mesonotum in dorsal view strongly constricted behind pronotum Prenolepis Mayr

- Mandible with seven or more teeth; antennal scape shorter, surpassing posterior margin of head by less than a third its length; mesonotum in dorsal view not strongly constricted behind pronotum Lasius Fabricius

38 Propodeum with a prominent conical tooth at the junction of the dorsal and declivitous faces; maxillary palp segment 3 elongate, subequal in length to segments 4-6; apical mandibular tooth much enlarged. Dorymyrmex Mayr

- Propodeum rounded or subangulate at the junction of the dorsal and declivitous faces, 
but without a conical tooth; maxillary palp segment 3 short, subequal in length to segments 4; apical mandibular tooth not notably enlarged .............................................. 39

39 Mesosoma dorsum lacking standing pilosity

- Mesosoma dorsum with standing pilosity

40 Petiole flattened, plate-like, and without a conspicuous, dorsally protruding scale (petiole often overhung by the succeeding abdominal segment); dorsal face of propodeum much shorter than the declivitous (posterior) face Tapinoma Foerster

- Petiole with a well developed, dorsally protruding scale; dorsal face of propodeum subequal in length to declivitous face Linepithema Mayr

41 In profile mesosoma dorsum without an impressed metanotal groove, the promesonotum and propodeum forming a continuous surface; workers variable in size within a colony Liometopum Mayr

- In profile mesosoma dorsum interrupted by a well marked metanotal groove; workers showing little intra-colony size variation

42 Petiole lacking an erect scale; side of mesosoma with conspicuous microreticulate sculpture; dark brown-black, with contrastingly paler tarsi Technomyrmex Mayr

- Petiole with well developed erect scale; side of mesosoma without conspicuous microreticulate sculpture; varying in color from yellowish-orange to dark brown, but without contrastingly paler tarsi Forelius Emery

\section{SYNOPSIS OF CALIFORNIA ANT GENERA}

\section{Subfamily Amblyoponinae}

\section{Genus Amblyopone Erichson}

Ants in the genus Amblyopone have cryptic foraging habits and are specialist predators on geophilomorph centipedes and other arthropods living in soil or rotten wood. Two species are known from California: A. oregonensis (Wheeler) is found in shaded, medium-elevation coniferous forests in northern California, while A. pallipes (Haldeman) is widespread in chaparral and low elevation woodland.

Species identification: Ward (1988). Additional references: Brown (1960a), Creighton (1940b), Haskins (1928), Lattke (1991d), Lacau and Delabie (2002), Traniello (1978, 1982).

\section{Subfamily Cerapachyinae}

\section{Genus Cerapachys F. Smith}

Ants in this genus are subterranean predators on other ants and they are not commonly 
encountered in California. Workers of $C$. augustae Wheeler have been recorded from three localities in southern coastal California (specimens in LACM and UCDC), while males of $C$. davisi M. R. Smith have been collected at light in desert locations in Imperial and San Bernardino Counties (Snelling \& George 1979).

Species identification: male key in Mackay and Mackay (2002). Additional references: Brown (1975), Smith (1942b), Snelling and George (1979), Wheeler (1902e, 1903j).

\section{Subfamily Dolichoderinae}

\section{Genus Dorymyrmex Mayr}

These generalist, ground-nesting ants are frequent in open habitats at medium to low elevations. The two commonest species, D. bicolor Wheeler and D. insanus (Buckley), are usually distinguishable on the basis of color, with the former being bicolored (head and mesosoma orange- or reddish-brown, metasoma brownish-black) and the latter unicolorous dark brown, but some samples are intermediate in color. Snelling (1995a) describes additional worker differences in head shape and eye size, but these characters are quite variable and are not always reliable. This group of ants continues to be burdened with taxonomic uncertainties, possibly as a result of occasional interspecific hybridization.

Species identification: key in Snelling (1995a). Additional references. Berkelhamer (1984), Johnson (1989b), Martinez (1995), Snelling and George (1979), Trager (1988a), Wheeler and Wheeler (1986g).

\section{Genus Forelius Emery}

These are hyperactive, thermophilic, ground-nesting ants, with two species (F. mccooki and F. pruinosus) in California. Colonies are polygynous, and the workers have conspicuous foraging trails. Some nest series consist of individuals phenotypically intermediate between $F$. mccooki and $F$. pruinosus, indicating the possibility of introgression between the two forms. Taxonomic difficulties with the group have been discussed previously (under "Taxonomic Changes").

Species identification: key in Wheeler and Wheeler (1986g). Additional references: Cuezzo (2000), Holway et al. (2002), Scheffrahn et al. (1984), Shattuck (1992c), Snelling and George (1979), Yensen et al. (1980).

\section{Genus Linepithema Mayr}

The introduced Argentine ant, L. humile (Mayr), is abundant in many urban and agricul- 
tural locations in lowland California, and it has invaded natural habitats along rivers and in some coastal regions. Workers avidly tend plant nectaries and honeydew-producing hemipterans. L. humile aggressively eliminates epigeic (above-ground foraging) native ant species (Ward 1987; Human \& Gordon 1996; Holway 1998). Most California populations of L. humile exhibit a unicolonial population structure, in which there is little or no intraspecific aggression, and they have reduced genetic diversity compared to native populations in Argentina (Tsutsui et al. 2000). Additional references (a sampling only): Buczkowski et al. (2004), Carney et al. (2003), Gordon et al. (2001), Heller (2004), Holway (1999), Holway et al. (1998, 2002), Holway and Suarez (2004), Human and Gordon (1997), Ingram and Gordon (2003), Knight and Rust (1990), Longcore (2003), Newell and Barber (1913), Sanders et al. (2001), Shattuck (1992a, 1992c), Smith (1965), Suarez et al. (1998, 1999, 2001), Tsutsui and Case (2001), Tsutsui et al. (2003), Vega and Rust (2001).

\section{Genus Liometopum Mayr}

This genus is represented in California by two species, both widespread. These ants have populous colonies that inhabit the trunks of large living trees, especially those of oak and pine. L. occidentale Emery tends to be associated with deciduous trees, while L. luctuosum Wheeler is found most frequently in conifers. The workers forage in large files and are generalist scavengers and predators, as well as active tenders of aphids and scale insects.

Species identification: key in Wheeler and Wheeler (1986g). Additional references: Disney (1982), Gulmahamad (1995), Kistner et al. (2002), Shapley (1920), Snelling and George (1979), Wheeler (1905h).

\section{Genus Tapinoma Foerster}

T. melanocephalum (Fabricius) is an introduced species, not definitively established in the state. T. sessile (Say) is a very common ant, found in almost all habitats in California except deserts and areas invaded by Linepithema humile. T. sessile shows substantial variation in size and color. At scattered locations in California a bicolored (orange and black) form of $T$. sessile occurs sympatrically with the typical unicolored dark brown/black morph. Workers of intermediate color have also been observed, suggesting that the two forms are conspecific. An alternative interpretation is that there are two species which occasionally exchange genes, perhaps analogous to the situation between Forelius mccooki and F. pruinosus and between Dorymyrmex bicolor and D. insanus.

Species identification: key in Creighton (1950a). Additional references: Meissner and Silverman (2001), Smith (1965), Wang and Brook (1970). 
This genus is represented by a single introduced species in the T. albipes complex, which occasionally establishes residence in hothouses (e.g., in Golden Gate Park, San Francisco). The group is under taxonomic revision by Barry Bolton (pers. comm.). References: Deyrup (1991), Ogata et al. (1996), Smith (1965), Tsuji et al. (1991), Yamauchi et al. (1991).

\section{Subfamily Ecitoninae}

\section{Genus Neivamyrmex Borgmeier}

This is the only genus of army ants found in California. These are nomadic, predacious ants that engage in group foraging. Workers are usually active at night, and often forage below the soil surface. Other ant species (both adults and brood) appear to be the principal prey items of Neivamyrmex, although the habits of the smaller, subterranean species are not well known.

Species identification: Snelling and Snelling (2005). Additional references: Borgmeier (1955), Gotwald (1995), Snelling and George (1979), Ward (1999), Watkins (1972, 1976, 1977b, 1985), Wheeler and Wheeler (1984a, 1986g).

\section{Subfamily Formicinae}

\section{Genus Brachymyrmex Mayr}

The name B. depilis Emery is provisionally attached to the single species of Brachymyrmex that occurs in California. It is widespread but infrequently encountered, in part because of its small size and inconspicuous foraging behavior. This is a ground-nesting species, recorded in California from sea level to 1900m. References: Creighton (1950a), Page (1982), Smith (1979), Wheeler and Wheeler (1986g), Yensen et al. (1980).

\section{Genus Camponotus Mayr}

Species of Camponotus (carpenter ants) are found in almost all terrestrial habitats of California, and include both ground-nesting and arboreal species. The workers are generalist scavengers and predators, and are most active at dusk and at night. Identification of the California species can be difficult. The keys cited below do not cover all of the species in this state, several of which are undescribed. The images on AntWeb provide additional assistance in identification. See also the description of Camponotus maritimus above (under "Taxonomic Changes"). 
Species identification: keys in Wheeler and Wheeler (1986g) and Mackay and Mackay (2002). Additional references: Brady et al. (2000), Chen et al., (2002), Creighton and Snelling (1967), Degnan et al. (2004), Gadau et al. (1999), Hansen and Akre (1985), MacArthur (2005), Sameshima et al. (1999), Sauer et al. (2000), Smith (1979), Snelling (1968b, 1970, 1988).

\section{Genus Formica Linnaeus}

In California the members of this genus are most prevalent in montane habitats, although a few species occur in drier, low elevation sites. Formica species are ground-nesting ants with generalist foraging habits. Francoeur's (1973) authoritative revision of the Formica fusca-group allows the species in that group to be relatively easily identified. Taxonomic difficulties still plague the Formica rufa-group, which contains most of the remaining species in California.

Species identification: keys in Francoeur (1973), Wheeler and Wheeler (1986g), Snelling and Buren (1985) and Mackay and Mackay (2002). Additional references: Agosti (1994b), Agosti and Bolton (1990b), Buren (1968a), Cole (1956d, 1956f, 1956g), Creighton (1940a, 1950a), Dlussky (1967), Francoeur and Snelling (1979), Gösswald (1989, 1990), Savolainen (1998), Smith (1979), Trager et al. (2005), Wilson and Brown (1955).

\section{Genus Lasius Fabricius}

These ground-nesting ants also tend to prefer cooler habitats at middle to high elevations. Workers are generalized scavengers and often tend hemipterans. Species in the subgenera Acanthomyops and Chthonolasius are temporary social parasites on other Lasius species. Species of Acanthomyops were previously considered to represent a different genus, but are now known to be phylogenetically nested within Lasius (see above under "Taxonomic Changes").

Species identification: keys in Wilson (1955a), Wing (1968) (Acanthomyops), and Mackay and Mackay (2002). Additional references: Agosti and Bolton (1990b), Cole (1956a, 1958a), Hasegawa (1998), Janda et al. (2004), MacKay (1998), Savolainen (2002), Seifert (1988a, 1992b), Umphrey and Danzmann (1998), Wheeler and Wheeler (1986g).

\section{Genus Myrmecocystus Wesmael}

These are the well-known "honeypot ants", whose colonies include a subgroup of specialized workers (repletes) devoted to storage of liquid food in their swollen abdomens. Spe- 
cies of Myrmecocytus are restricted to the western United States and northern Mexico and are found primarily in desert habitats. Snelling's (1976) landmark revision of the genus also contains much useful biological information.

Species identification: keys in Snelling (1976, 1982b). Additional references: DinizFilho and Fowler (1998), Duncan and Lighton (1994a, 1994b), Hölldobler (1976b, 1986), Kay and Whitford (1978), Kronauer et al. (2003, 2004), Lloyd et al. (1989), Rissing (1984), Snelling (1969b, 1971a), Snelling and George (1979), Smith (1979), Wheeler and Wheeler $(1986 \mathrm{~g})$.

\section{Genus Paratrechina Motschoulsky}

These ground-dwelling ants are infrequently encountered in natural habitats of California, except $P$. hystrix Trager, a desert species. P. vividula (Nylander) is common in many urban locations, and behaves like an introduced species, although it is assumed to be native to Mexico (Trager 1984b). A second tramp species, P. longicornis (Latreille), of Old World origin, is established at some locations in southern California.

Species identification: keys in Trager (1984). Additional references: Creighton (1950a), MacKay (1998), Smith (1965), Saporito et al. (2004), Wetterer et al. (1999).

\section{Genus Plagiolepis Mayr}

A single introduced species, P. alluaudi Emery, has been recorded from the state (Catalina Island). The genus is of Old World origin. References: Smith (1958b), Smith (1979), Wilson and Taylor (1967).

\section{Genus Polyergus Latreille}

The members of this genus are obligate slave-raiders of other ants, mostly species in the Formica fusca-group. The California populations of Polyergus are here treated as a single variable species, $P$. breviceps Emery. This implies synonymy of $P$. laeviceps Wheeler (type locality: Mt. Tamalpais, California) under P. breviceps but no formal change is proposed here because the entire complex needs comprehensive taxonomic evaluation. Within California there is considerable interregional variation in worker morphology and biology (including the host species attacked), but I have seen no evidence of more than one species occurring in any given locality. One might expect there to be pronounced interpopulation variation in $P$. breviceps because of the limited dispersal of the queens (Topoff 1999). References (partial list): Agosti (1994b), Creighton (1950a), Greenberg et al. (2004), Hasegawa et al. (2002), Hölldobler (1985), Topoff (1990, 1999), Wheeler (1968). 
P. imparis Say is very common in mesic habitats at low and medium elevations throughout most of the state. Nests are located deep in the ground, and workers do not forage during the hottest periods of summer. A collection of unusually small alate queens from one locality in the foothills of the Sierra Nevada appears to represent a second, undescribed species, which might be a social parasite of $P$. imparis (Wild 2002). References: Creighton (1950a), Fontenla (2000), Lynch et al. (1980), Smith (1965), Tschinkel (1987), Wheeler (1930c).

\section{Subfamily Myrmicinae}

\section{Genus Acromyrmex Mayr}

These leaf-cutting ants are represented in California by a single species, Acromyrmex versicolor (Pergande), confined to the southern deserts. The harvested leaves are used to culture a basidiomycete fungus, which is the principal food of the ants. References: Gamboa (1975, 1976), Johnson and Rissing (1993), Julian and Fewell (2004), Mueller et al. (2001), Reichardt and Wheeler (1996), Rissing et al. (1986, 1989), Snelling and George (1979), Weber (1972).

\section{Genus Aphaenogaster Mayr}

Of the six species of this genus occurring in California, one (A. occidentalis (Emery)) is widespread in mesic habitats, four are confined to deserts, and one species (A. patruelis Forel) is endemic to the Channel Islands and Isla Guadalupe. All are ground-nesting ants, with somewhat generalized scavenging habits.

Species identification: keys in Creighton (1950a), Wheeler and Wheeler (1986g) and Mackay and Mackay (2002). Additional references: Creighton (1955), De Andrade (1995), Hölldobler and Carlin (1990), Hölldobler et al. (1995), Johnson (2000a, 2001), Jones and Phillips (1989), Sanders and Gordon (2002), Schulz (1994), Smith (1963c), Umphrey (1996), Wheeler and Creighton (1934).

\section{Genus Cardiocondyla Emery}

These minute ants are of Old World origin but several species have become widespread vagrants. Two of these occur in disturbed (mostly urban) habitats in California, where they nest in sidewalks and along roadways. Both are able to survive in sites invaded by 
the Argentine ant (Linepithema humile). The males of Cardiocondyla occur in two forms: dispersing winged males and wingless, worker-like (ergatoid) males that mate in the nest.

Species identification: keys in Seifert (2003). Additional references: Anderson et al. (2003), Creighton and Snelling (1974), Cremer and Heinze (2003), Gulmahamad (1997), Heinze (1999), Heinze and Hölldobler (1993B), Heinze et al. (2004), Kugler (1984), MacKay (1995), Snelling (1974).

\section{Genus Crematogaster Lund}

This large cosmopolitan genus is represented in California by both arboreal and groundnesting species. Nine species have been recorded from the state but taxonomic uncertainties undermine this statistic. C. opuntiae Buren is quite similar to, and possibly conspecific with, $C$. californica Wheeler; the differences between $C$. coarctata Mayr and $C$. mormonum Wheeler are slight and unreliable; and the record of $C$. larreae Buren from California may be a misidentification. The North American species of this genus are much in need of a taxonomic update.

Species identification: keys in Buren (1968b). Additional references: Buren (1959), Longino (2003), Mackay and Mackay (2002), Scheffrahn and Rust (1989), Snelling and George (1979), Wheeler and Krutzsch (1994).

\section{Genus Cyphomyrmex Mayr}

There are two species of Cyphomyrmex recorded from California, both ground-nesting and infrequently encountered. These fungus-growing ants collect caterpillar frass and other organic matter, on which they cultivate fungal mycelia or (in some species) yeasts.

Species identification: keys in Snelling and Longino (1992). Additional references: De Andrade (2003), Kempf (1964d, 1966), Schultz et al. (2002), Weber (1972).

\section{Genus Formicoxenus Mayr}

A single species, F. diversipilosus (M. Smith) occurs in northern California, where it lives as a "guest-ant" in the mound nests of species in the Formica rufa-group, such as F. integroides Wheeler and F. obscuripes Forel. Colonies of Formicoxenus occupy dead twigs within the larger mound nests, and apparently scavenge organic material gathered by the host ant. References: Alpert and Akre (1973), Bolton (2003), Buschinger (1979a), Francoeur et al. (1985), Lenoir et al. (1997), Smith (1939c), Snelling (1965a). 
Most species formerly placed in this genus have been reassigned to Nesomyrmex and Temnothorax, leaving Leptothorax much more narrowly and precisely circumscribed (Bolton 2003). Nevertheless, the species-level taxonomy of the North American Leptothorax remains in a state of chaos. There are at least two species in California: one can be easily identified as L. calderoni (see "Taxonomic Changes" above), while the remaining collections-here assigned the code name Leptothorax sp. CA-01-cannot be identified with certainty. They belong to the muscorum-complex, which is widespread in temperate North America and Eurasia, and within which species limits are ill-defined. References: Bolton (2003), Brown (1955a), Buschinger and Heinze (1993), Cole (1954d), Creighton (1950a), Douwes and Stille (1987), Francoeur (1986b), Francoeur et al. (1985), Heinze (1989b, 1991, 1998), Heinze et al. (1996), Loiselle et al. (1990), Möglich (1979).

\section{Genus Manica Jurine}

All four North American species of this Holarctic genus occur in California, where they are confined to montane and high desert locations. Detailed notes on the distribution and nesting habits of the species are given by Wheeler and Wheeler (1970a). One species, $M$. parasitica Creighton, is known only from peculiar shiny workers collected in the nests of M. bradleyi (Wheeler), of which it is presumed to be a parasite, but its taxonomic status remains unclear.

Species identification: keys in Wheeler and Wheeler (1986g). Additional references: Creighton (1934), Fales et al. (1972), Went et al. (1972), Wheeler and Wheeler (1968b, 1970a), Wheeler (1914e).

\section{Genus Messor Forel}

These are granivorous ants whose nest entrances are usually surrounded by conspicuous piles of seed chaff. The seven California species are found mostly in open, dry habitats. There is some evidence that the Nearctic species of Messor are more closely related to a group of New World Aphaenogaster (those belonging to the erstwhile genus Novomessor) than to the Old World species of Messor (Bennett 2000). If confirmed this would warrant redefinition of Messor and resurrection of Veromessor, the genus name previously applied to the Nearctic species. Unfortunately Aphaenogaster itself is likely to be paraphyletic and a comprehensive overhaul of the entire tribe Pheidolini, in which these ants have been placed, is needed.

Species identification: keys in Smith (1956a) and Wheeler and Wheeler (1986g). Additional references: Bennett (2000), Boulton et al. (2003), Brown (1999a, 1999b), 

son (1977a, 1978), Helms Cahan (2001), Hobbs (1985), Johnson (2000a, 2001), O’Dowd and Hay (1980), Rissing and Wheeler (1976), Ryti and Case (1988), Waser (1998), Went et al. (1972), Wheeler and Rissing (1975a, 1975b), Wheeler and Creighton (1934).

\section{Genus Monomorium Mayr}

California appears to have a single indigenous species of this genus, M. ergatogyna, a ground-nesting species which is widely but patchily distributed throughout the state except at high elevations. The reasons for treating $M$. wheelerorum as a junior synonym have been discussed above (under "Taxonomic Changes"). The introduced Pharaoh's ant, $M$. pharaonis (Linnaeus), is a frequent pest in buildings in urban California. A second introduced species, similar to $M$. pharaonis but with a more elongate head and more shagreened sculpture, has been collected once in the state (images and locality information on AntWeb).

Species identification: keys in Wheeler and Wheeler (1986g). Additional references: Adams and Traniello (1981), Andersen et al. (1991), Berndt and Eichler (1987), Bolton (1987), DuBois (1986, 2000), Fernández (2005), Heterick (2001), Jones et al. (1982a, 1982b), Knight and Rust (1990).

\section{Genus Myrmecina Curtis}

The members of this genus are small, cryptobiotic ants that live in soil, leaf litter and rotten logs. Studies of two Asian species suggest that these ants are specialized as mite predators (Masuko 1995). California has a single species, M. americana Emery, that is known from scattered low-elevation sites throughout the state. It was previously considered to represent a distinct, endemic taxon (M. californica M. R. Smith). The California populations exhibit considerable variation in color and sculpture, however, making it difficult to establish a clear distinction between them and other western populations of M. americana. References: Brown (1967c), Buschinger (2003), Buschinger and Schreiber (2002), Masuko (1995), Murakami et al. (2002), Smith (1948), Snelling (1965b), Ward (1988).

\section{Genus Myrmica Latreille}

This is a Holarctic genus of ground-nesting ants, with generalized foraging habits. Like most members of the genus, the California species are found predominantly in temperate habitats such as coniferous forests and montane meadows, but one rare species (M. rugiventris (M. R. Smith)) occurs in chaparral, oak woodland and coastal scrub. A revision of the Nearctic species is in preparation by André Francoeur. 
Species identification: keys in Creighton (1950a), Wheeler and Wheeler (1986g) and Mackay and Mackay (2002). Additional references: Bolton (1988a), Evans (1995, 1996a, 1996b), Francoeur (2005), Radchenko (1994a, 1994d), Seifert (1988b), Weber (1939b, 1947b, 1948a, 1950c).

\section{Genus Pheidole Westwood}

This is one of the world's largest ant genera, with more than 600 species recognized in the New World alone (Wilson 2003). The native California Pheidole are all ground-dwelling species, found in open, dry habitats. A few of the species are generalized scavengers, but most belong to a group of seed-harvesting specialists, the $P$. pilifera-group, with fifteen species in the state. There are also three introduced species, currently of limited distribution and confined to urban areas.

Species identification: keys in Gregg (1959), Wheeler and Wheeler (1986g) and Wilson (2003). Additional references: Clark et al. (1986), Cole (1956c), Creighton and Gregg (1955), Davidson (1977a), Johnson (2000a, 2000b, 2001), Langen et al. (2000), Martinez (1992, 1996, 1997), Snelling (1992b), Snelling and George (1979), Ward (2000), Wheeler and Wheeler (1973e).

\section{Genus Pogonomyrmex Mayr}

The species in this genus are seed-harvesting ants, whose nest mounds are often conspicuously decorated with pebbles. The workers are diurnal and have a potent sting. Several of the taxa belong to difficult complexes, and species boundaries remain unclear. In neighboring Arizona a series of stabilized hybrid lineages has been documented in the P. barbatus-complex (Helms Cahan et al. 2002).

Species identification: keys in Cole (1966), Wheeler and Wheeler (1986g) and Mackay and Mackay (2002). Additional references: Davidson (1977a), De Vita (1979), Gordon (1999), Groark (2001), Helms Cahan et al. (2002), Hölldobler (1976a, 1976c), Johnson (2000a, 2001), Knudtson (1978), Kusnezov (1951e), Lei (2000), MacKay (1980, 1981, 1982), MacKay and MacKay (1989), O’Dowd and Hay (1980), Olsen (1934), Parker and Rissing (2002), Ryti and Case (1988), Schmidt (1998), Shattuck (1987), Snelling (1982a), Taber (1990, 1998), Taber et al. $(1987,1988)$, Wheeler (1902a, 1914e).

\section{Genus Pyramica Roger}

Three species of Pyramica have been recorded from California, of which two are endemic and one is introduced from the Old World. These are rare, cryptobiotic ants, thought to be specialist predators on springtails and other small arthropods. 
Species identification: keys in Ward (1988) and Bolton (2000). Additional references: Bolton (1999), Brown (1953g), Brown and Wilson (1959b), Dejean (1985b), Wilson (1954a).

\section{Genus Rogeria Emery}

A single, apparently undescribed species of this predominantly Neotropical genus has been collected once in Orange County (images and locality data on AntWeb). References: Kugler (1994).

\section{Solenopsidini new genus}

The sole species in this undescribed genus has blind, subterranean workers and is known only from desert regions of southwestern United States. A description is in preparation, based on collections of workers, queens and males from southeastern Arizona (Cover \& Deyrup 2005). Alates of apparently the same species have been collected in southern California. Mackay and Mackay (2003) recorded the same species from New Mexico and tentatively assigned it to the genus Tranopelta Mayr.

\section{Genus Solenopsis Westwood}

Two groups of Solenopsis occur in California. "Fire ants" are relatively large, grounddwelling species, with generalized foraging habits, aggressive workers and a painful sting. They include the widespread native species, S. xyloni McCook, and the recently introduced S. invicta Buren (red imported fire ant). "Thief ants" are small to minute species, previously placed in the subgenus Diplorhoptrum. These ants are predominantly subterranean, and difficult to identify.

Species identification: keys in Trager (1991) (fire ants), Wheeler and Wheeler (1986g) and Mackay and Mackay (2002). Additional references: Buren (1972), Creighton (1930b), Gorman et al. (1998), Jones et al. (1982a), Knight and Rust (1990), Korzukhin et al. (2001), Morrison (2002), Porter and Savignano (1990), Ross and Trager (1991), Taber (2000), Thompson (1989).

\section{Genus Stenamma Westwood}

The species in this genus nest in soil and rotting wood, usually in mesic habitats. Stenamma workers have rather cryptic foraging habits, and are often encountered in litter 
samples. California appears to a center of ongoing diversification for the group, resulting in a number of taxonomic difficulties. For identification purposes the images on AntWeb should be examined in consultation with the keys in Snelling (1973c).

Species identification: keys in Snelling (1973c). Additional references: Cole (1966b), DuBois (1998), Smith (1957b), Wheeler and Wheeler (1986g).

\section{Genus Strumigenys F. Smith}

Strumigenys is a predominantly tropical genus, represented in California by a single, nonnative species, S. silvestrii Emery. Species in this genus whose biology has been studied are specialist predators of springtails and other small arthropods. References: Bolton (1999, 2000), Brown (1959f), Brown and Wilson (1959b), Dejean (1987), Wilson (1954a).

\section{Genus Temnothorax Mayr}

Most of the California species formerly placed in Leptothorax have now been assigned to Temnothorax (Bolton 2003). With at least twenty species in California, this is a diverse group showing wide variation in habitat and nest-site preferences. About a third of the species are arboreal. Most species appear to be generalist scavengers.

Species identification: keys in Wheeler and Wheeler (1986g) and Mackay (2000), in conjunction with the new synonymy introduced here (see above under "Taxonomic Changes") and images on AntWeb. Additional references: Bolton (2003), Cole (1958c), Creighton (1950a), Deyrup and Cover (2004), Douwes and Stille (1987), Möglich (1979), Smith (1949e), Wheeler (1903d).

\section{Genus Tetramorium Mayr}

There is one native species of Tetramorium in California, T. spinosum (Pergande), which occurs in open dry habitats of southern California, and one introduced European species, T. caespitum (Linnaeus) (the pavement ant), which is found in urban and agricultural areas of central and northern California. Both are ground-nesting, with generalist foraging habits. Four other non-native species, of tropical origin, have been recorded occasionally from the state.

Species identification: keys in Bolton (1979). Additional references: Astruc et al. (2001), Brown (1957d), Bruder and Gupta (1972), Knight and Rust (1990), Longhurst et al. (1980), Martinez (1993), Merickel and Clark (1994), Sanetra and Buschinger (2000), Steiner et al. (2005). 
Wasmannia auropunctata (Roger) has been recorded occasionally from southern California. Native to the Neotropics, this aggressive species has not become established in California, probably because of climatic unsuitability. It is considered ecologically destructive in other areas where it has successfully invaded. References: Jourdan (1997), Le Breton et al. (2004), Longino and Fernández (2005), Lubin (1984), Ulloa-Chacón and Cherix (1990), Wetterer and Porter (2003).

\section{Subfamily Ponerinae}

\section{Genus Hypoponera Santschi}

This is a cosmopolitan genus of small predacious ants, nesting in soil and rotten wood. Four species are known from California, of which one (Hypoponera sp. CA-01) is apparently undescribed and not included in the keys cited below. It is similar to Hypoponera opacior (Forel) from which it can be distinguished by the orange-brown body color (usually dark brown in California H. opacior), narrower head (CI 0.77-0.83, as opposed to 0.83-0.87 in H. opacior), and conspicuous standing pilosity on the venter of the head (such pilosity sparse in California populations of $H$. opacior).

Species identification: keys in Creighton (1950a), Wheeler and Wheeler (1986g) and Mackay and Mackay (2002). Additional references: Delabie and Blard (2002), Duffield et al. (1976), Foitzik et al. (2002), Taylor (1967a).

\section{Subfamily Proceratiinae}

\section{Genus Proceratium Roger}

A single, rare species of Proceratium has been recorded from California. Endemic to the state, $P$. californicum Cook is known from valley oak woodland in the Central Valley and from woodland, chaparral and grassland sites in adjacent foothill localities. It is presumed to be a specialist, subterranean predator; some other members of the genus have been shown to prey on spider eggs. References: Baroni Urbani and de Andrade (2003), Brown (1958g, 1958j, 1980c), de Andrade and Baroni Urbani (2003), Onoyama and Yoshimura (2002), Snelling (1967), Ward (1988). 


\section{Genus Pseudomyrmex Lund}

Ants in this predominantly Neotropical genus nest in hollow dead twigs and other preformed plant cavities. Two species occur in California: P. apache Creighton is widespread at middle and low elevations within the California floristic province, often nesting in branches of manzanita (Arctostaphylos), while P. pallidus (F. Smith) is confined to southern California.

Species identification: Ward (1985b). Additional references: Creighton (1953b, 1954), Peters (1997), Starks et al. (1998), Ward (1989a, 1990, 1993).

\section{ACKNOWLEDGEMENTS}

I am grateful to the following individuals for access to ant specimens in the indicated collections: Woyciech Pulawski and Brian Fisher (CASC), John Sorensen (CDAE), Roy Snelling (LACM), Stefan Cover (MCZC), Bernhard Merz (MHNG), Robert Johnson (RAJC), Ted Schultz (USNM) and William Mackay (WPMC). I also received useful samples of California ants from April Boulton, Lisa DiGirolamo, Robert Fisher, Susan Harrison, David Holway, Jim des Lauriers, Andrew Suarez and Mark Trepanier. Alex Wild kindly examined and photographed the holotype of Temnothrax andrei during a visit to MCSN, Genoa. Figures 1-2 and 5-10 are taken from Automontage images produced by April Nobile at the California Academy of Sciences for AntWeb (www.antweb.org). Brian Fisher conceptualized and developed AntWeb, including a component devoted to images of California ants. The growing popularity of AntWeb provided an incentive for timely completion of this paper. I thank Mark Deyrup, Brian Fisher and Roy Snelling for helpful comments on the manuscript. My field work and taxonomic studies on ants have been supported by the University of California at Davis and the National Science Foundation (most recently grant DEB-0431330).

\section{REFERENCES}

In addition to literature citations from the main text, this bibliography also includes the original species descriptions and other references cited in the Appendix. In the case of multiple publications by the same author or combination of authors in a year, the suffix (letter) appended to the year corresponds to that used in Ward et al. (1996), for items published prior to 1996.

Adams, E.S. \& Traniello, J.F.A. (1981) Chemical interference competition by Monomorium minimum (Hymenoptera: Formicidae). Oecologia (Berlin), 51, 265-270. 
Agosti, D. (1994b) The phylogeny of the ant tribe Formicini (Hymenoptera: Formicidae) with the description of a new genus. Systematic Entomology, 19, 93-117.

Agosti, D. \& Bolton, B. (1990b) New characters to differentiate the ant genera Lasius F. and Formica L. (Hymenoptera: Formicidae). Entomologist's Gazette, 41, 149-156.

Alpert, G.D. \& Akre, R.D. (1973) Distribution, abundance, and behavior of the inquiline ant Leptothorax diversipilosus. Annals of the Entomological Society of America, 66, 753-760.

Andersen, A. N., Blum, M. S. \& Jones, T. H. (1991) Venom alkaloids in Monomorium "rothsteini" Forel repel other ants: is this the secret to success by Monomorium in Australian ant communities? Oecologia (Berlin), 88, 157-160.

Anderson, C., Cremer, S. \& Heinze, J. (2003) Live and let die: why fighter males of the ant Cardiocondyla kill each other but tolerate their winged rivals. Behavioral Ecology, 14, 54-62

André, E. (1893b) Description de quatre espèces nouvelles de fourmis d'Amérique. Revue d'Entomologie (Caen), 12, 148-152.

Arnett, R.H., Jr., Samuelson, G.A. \& Nishida, G.M. (1993) The insect and spider collections of the world. Second edition. Sandhill Crane Press, Gainesville, vi +310 pp.

Astruc, C., Malosse, C. \& Errard, C. (2001) Lack of intraspecific aggression in the ant Tetramorium bicarinatum: a chemical hypothesis. Journal of Chemical Ecology, 27, 1229-1248.

Bakker, E.S. (1984) An island called California. University of California Press, Berkeley, California, xii +484 pp.

Baroni Urbani, C. \& de Andrade, M.L. (2003) The ant genus Proceratium in the extant and fossil record (Hymenoptera: Formicidae). Museo Regionale di Scienze Naturali Monografie (Turin), $36,1-492$.

Bennett, M. (2000) Systematics of the Nearctic granivore ant genus Veromessor (Hymenoptera: Formicidae). Unpublished Ph.D. Thesis, University of California, Davis.

Berkelhamer, R.C. (1984) An electrophoretic analysis of queen number in three species of dolichoderine ants. Insectes Sociaux, 31, 132-141.

Berndt, K.-P. \& Eichler, W. (1987) Die Pharaoameise, Monomorium pharaonis (L.) (Hym., Myrmicidae). Mitteilungen aus dem Zoologischen Museum in Berlin, 63, 3-186.

Bolton, B. (1979) The ant tribe Tetramoriini (Hymenoptera: Formicidae). The genus Tetramorium Mayr in the Malagasy region and in the New World. Bulletin of the British Museum (Natural History). Entomology, 38, 129-181.

Bolton, B. (1987) A review of the Solenopsis genus-group and revision of Afrotropical Monomorium Mayr (Hymenoptera: Formicidae). Bulletin of the British Museum (Natural History). Entomology, 54, 263-452.

Bolton, B. (1988a) A new socially parasitic Myrmica, with a reassessment of the genus (Hymenoptera: Formicidae). Systematic Entomology, 13, 1-11.

Bolton, B. (1994) Identification guide to the ant genera of the world. Harvard University Press, Cambridge, Massachusetts, $222 \mathrm{pp}$.

Bolton, B. (1995b) A new general catalogue of the ants of the world. Harvard University Press, Cambridge, Massachusetts, 504 pp.

Bolton, B. (1999) Ant genera of the tribe Dacetonini (Hymenoptera: Formicidae). Journal of Natural History, 33, 1639-1689.

Bolton, B. (2000) The ant tribe Dacetini. Memoirs of the American Entomological Institute, 65, 11028.

Bolton, B. (2003) Synopsis and classification of Formicidae. Memoirs of the American Entomological Institute, 71, 1-370.

Borgmeier, T. (1955) Die Wanderameisen der neotropischen Region. Studia Entomologica, 3, 1720.

Boulton, A.M., Jaffee, B.A. \& Scow, K.M. (2003) Effects of a common harvester ant (Messor andrei) on richness and abundance of soil biota. Applied Soil Ecology, 23, 257-265. 
Brady, S.G., Gadau, J. \& Ward, P.S. (2000) Systematics of the ant genus Camponotus (Hymenoptera: Formicidae): a preliminary analysis using data from the mitochondrial gene cytochrome oxidase I. In: Austin, A. D. \& Dowton, M. (Eds), Hymenoptera. Evolution, biodiversity and biological control. CSIRO Publishing, Collingwood, Victoria, pp. 131-139.

Brown, M.J.F. (1999a) Nest relocation and encounters between colonies of the seed-harvesting ant Messor andrei. Insectes Sociaux, 46, 66-70.

Brown, M.J.F. (1999b) Semi-claustral founding and worker behaviour in gynes of Messor andrei. Insectes Sociaux, 46, 194-195.

Brown, M.J.F. \& Human, K.G. (1997) Effects of harvester ants on plant species distribution and abundance in a serpentine grassland. Oecologia (Berlin), 112, 237-243.

Brown, W.L., Jr. (1950d) Preliminary descriptions of seven new species of the dacetine ant genus Smithistruma Brown. Transactions of the American Entomological Society, 76, 37-45.

Brown, W.L., Jr. (1953g) Revisionary studies in the ant tribe Dacetini. American Midland Naturalist, 50, 1-137.

Brown, W.L., Jr. (1955a) The ant Leptothorax muscorum (Nylander) in North America. Entomological News, 66, 43-50.

Brown, W.L., Jr. (1957d) Is the ant genus Tetramorium native in North America? Breviora, 72, 1-8.

Brown, W.L., Jr. (1958g) Contributions toward a reclassification of the Formicidae. II. Tribe Ectatommini (Hymenoptera). Bulletin of the Museum of Comparative Zoology, 118, 173-362.

Brown, W.L., Jr. (1958j (“1957”)) Predation of arthropod eggs by the ant genera Proceratium and Discothyrea. Psyche (Cambridge), 64, 115.

Brown, W.L., Jr. (1959f) The neotropical species of the ant genus Strumigenys Fr. Smith: group of silvestrii Emery. Studia Entomologica, (n.s.)2, 25-30.

Brown, W.L., Jr. (1960a) Contributions toward a reclassification of the Formicidae. III. Tribe Amblyoponini (Hymenoptera). Bulletin of the Museum of Comparative Zoology, 122, 143230.

Brown, W.L., Jr. (1967c) Studies on North American ants. II. Myrmecina. Entomological News, 78, 233-240.

Brown, W.L., Jr. (1975) Contributions toward a reclassification of the Formicidae. V. Ponerinae, tribes Platythyreini, Cerapachyini, Cylindromyrmecini, Acanthostichini, and Aenictogitini. Search. Agriculture (Ithaca, New York), 5(1), 1-115.

Brown, W.L., Jr. (1980c ("1979")) A remarkable new species of Proceratium, with dietary and other notes on the genus (Hymenoptera: Formicidae). Psyche (Cambridge), 86, 337-346.

Brown, W.L., Jr. \& Wilson, E.O. (1959b) The evolution of the dacetine ants. Quarterly Review of Biology, 34, 278-294.

Bruder, K.W. \& Gupta, A.P. (1972) Biology of the pavement ant, Tetramorium caespitum (Hymenoptera: Formicidae). Annals of the Entomological Society of America, 65, 358-367.

Buckley, S.B. (1866) Descriptions of new species of North American Formicidae. Proceedings of the Entomological Society of Philadelphia, 6, 152-172.

Buckley, S.B. (1867) Descriptions of new species of North American Formicidae (continued from page 172). Proceedings of the Entomological Society of Philadelphia, 6, 335-350.

Buczkowski, G., Vargo, E.L. \& Silverman, J. (2004) The diminutive supercolony: the Argentine ants of the southeastern United States. Molecular Ecology, 13, 2235-2242.

Buren, W.F. (1959 ("1958")) A review of the species of Crematogaster, sensu stricto, in North America (Hymenoptera: Formicidae). Part I. Journal of the New York Entomological Society, 66, 119-134.

Buren, W.F. (1968a) Some fundamental taxonomic problems in Formica (Hymenoptera: Formicidae). Journal of the Georgia Entomological Society, 3, 25-40.

Buren, W.F. (1968b) A review of the species of Crematogaster, sensu stricto, in North America (Hymenoptera, Formicidae). Part II. Descriptions of new species. Journal of the Georgia Ento- 
mological Society, 3, 91-121.

Buren, W.F. (1972) Revisionary studies on the taxonomy of the imported fire ants. Journal of the Georgia Entomological Society, 7, 1-26.

Buschinger, A. (1979a) Functional monogyny in the American guest ant Formicoxenus hirticornis (Emery) (= Leptothorax hirticornis), (Hym., Form.). Insectes Sociaux, 26, 61-68.

Buschinger, A. (2003) Mating behavior in the ant, Myrmecina graminicola (Myrmicinae). Insectes Sociaux, 50, 295-296.

Buschinger, A. \& Heinze, J. (1993) Doronomyrmex pocahontas: not a workerless parasite but still an enigmatic taxon (Hymenoptera, Formicidae). Insectes Sociaux, 40, 423-432.

Buschinger, A. \& Schreiber, M. (2002) Queen polymorphism and queen-morph related facultative polygyny in the ant, Myrmecina graminicola (Hymenoptera, Formicidae). Insectes Sociaux, 49, 344-353.

Cahan, S., Helms, K.R. \& Rissing, S.W. (1998) An abrupt transition in colony founding behaviour in the ant Messor pergandei. Animal Behaviour, 55, 1583-1594.

Carney, S.E., Byerley, M.B. \& Holway, D.A. (2003) Invasive Argentine ants (Linepithema humile) do not replace native ants as seed dispersers of Dendromecon rigida (Papaveraceae) in California, USA. Oecologia (Berlin), 135, 576-582.

Chen, Y., Hansen, L.D., Brown, J.J. (2002) Nesting sites of the carpenter ant, Camponotus vicinus (Mayr) (Hymenoptera: Formicidae) in northern Idaho. Environmental Entomology, 31, 10371042.

Clark, W.H., Blom, P.E. \& Lowman, A.M. (1986) Contents of a nest of the desert ant, Pheidole grallipes Wheeler, in Baja California, México. Pan-Pacific Entomologist, 62, 99-102.

Cole, A.C., Jr. (1936b) Descriptions of seven new western ants. (Hymenop.: Formicidae). Entomological News, 47, 118-121.

Cole, A.C., Jr. (1938b) A new ant from Idaho's semidesert. American Midland Naturalist, 19, 678681.

Cole, A.C., Jr. (1954d) Studies of New Mexico ants. X. The genus Leptothorax (Hymenoptera: Formicidae). Journal of the Tennessee Academy of Science, 29, 240-241.

Cole, A.C., Jr. (1956a) Studies of Nevada ants. II. A new species of Lasius (Chthonolasius) (Hymenoptera: Formicidae). Journal of the Tennessee Academy of Science, 31, 26-27.

Cole, A.C., Jr. (1956c) Observations of some members of the genus Pheidole in the southwestern United States with synonymy (Hymenoptera: Formicidae). Journal of the Tennessee Academy of Science, 31, 112-118.

Cole, A.C., Jr. (1956d) In defense of the integrity of an ant. Journal of the Tennessee Academy of Science, 31, 212-214.

Cole, A.C., Jr. (1956f) Studies of Nevada ants. III. The status of Formica nevadensis Wheeler (Hymenoptera: Formicidae). Journal of the Tennessee Academy of Science, 31, 256-257.

Cole, A.C., Jr. (1956g) Studies of Nevada ants. IV. Descriptions of sexual castes of three members of the rufa group of the genus Formica L. Journal of the Tennessee Academy of Science, 31, 257-260.

Cole, A.C., Jr. (1958a) A remarkable new species of Lasius (Chthonolasius) from California (Hymenoptera: Formicidae). Journal of the Tennessee Academy of Science, 38, 75-77.

Cole, A.C., Jr. (1958c) North American Leptothorax of the nitens-carinatus complex (Hymenoptera: Formicidae). Annals of the Entomological Society of America, 51, 535-538.

Cole, A.C., Jr. (1963a) A new species of Veromessor from the Nevada Test Site and notes on related species (Hymenoptera: Formicidae). Annals of the Entomological Society of America, 56, 678682.

Cole, A.C., Jr. (1966b) Ants of the Nevada Test Site. Brigham Young University Science Bulletin. Biological Series, 7(3), 1-27.

Cole, A.C., Jr. (1968) Pogonomyrmex harvester ants. A study of the genus in North America. Uni- 
versity of Tennessee Press, Knoxville, Tennessee, $\mathrm{x}+222 \mathrm{pp}$.

Cook, T.W. (1953) The ants of California. Pacific Books, Palo Alto, California, 462 pp.

Cover, S. \& Deyrup, M. (2005) A new genus of ant from southwestern United States. Memoirs of the American Entomological Institute, in press.

Creighton, W.S. (1930b) The New World species of the genus Solenopsis (Hymenop. Formicidae). Proceedings of the American Academy of Arts and Sciences, 66, 39-151.

Creighton, W.S. (1934) Descriptions of three new North American ants with certain ecological observations on previously described forms. Psyche (Cambridge), 41, 185-200.

Creighton, W.S. (1940a) A revision of the North American variants of the ant Formica rufa. American Museum Novitates, 1055, 1-10.

Creighton, W.S. (1940b) A revision of the forms of Stigmatomma pallipes. American Museum Novitates, 1079, 1-8.

Creighton, W.S. (1950a) The ants of North America. Bulletin of the Museum of Comparative Zoology, 104, 1-585.

Creighton, W.S. (1953a) New data on the habits of the ants of the genus Veromessor. American Museum Novitates, 1612, 1-18.

Creighton, W.S. (1953b ("1952")) Pseudomyrmex apache, a new species from the southwestern United States (Hymenoptera: Formicidae). Psyche (Cambridge), 59, 131-142.

Creighton, W.S. (1954) Additional studies on Pseudomyrmex apache (Hymenoptera: Formicidae). Psyche (Cambridge), 61, 9-15.

Creighton, W.S. (1955) Studies on the distribution of the genus Novomessor (Hymenoptera: Formicidae). Psyche (Cambridge), 62, 89-97.

Creighton, W.S. \& Gregg, R. E. (1955) New and little-known species of Pheidole (Hymenoptera: Formicidae) from the southwestern United States and northern Mexico. University of Colorado Studies. Series in Biology, 3, 1-46.

Creighton, W. S. \& Snelling, R. R. (1967 (“1966”)) The rediscovery of Camponotus (Myrmaphaenus) yogi Wheeler (Hymenoptera: Formicidae). Psyche (Cambridge), 73, 187-195.

Creighton, W. S. \& Snelling, R. R. (1974) Notes on the behavior of three species of Cardiocondyla in the United States (Hymenoptera: Formicidae). Journal of the New York Entomological Society, 82, 82-92.

Cremer, S. \& Heinze, J. (2003) Stress grows wings: environmental induction of winged dispersal males in Cardiocondyla ants. Current Biology, 13, 219-223.

Cresson, E.T. (1865b) Catalogue of Hymenoptera in the collection of the Entomological Society of Philadelphia, from Colorado Territory. [concl.] Proceedings of the Entomological Society of Philadelphia, 4, 426-488.

Cresson, E.T. (1872) Hymenoptera Texana. Transactions of the American Entomological Society, 4, 153-292.

Cuezzo, F. (2000) Revisión del género Forelius (Hymenoptera: Formicidae: Dolichoderinae). Sociobiology, 35, 197-275.

Davidson, D.W. (1977a) Species diversity and community organization in desert seed-eating ants. Ecology, 58, 711-724.

Davidson, D.W. (1978) Size variability in the worker caste of a social insect (Veromessor pergandei Mayr) as a function of the competitive environment. American Naturalist, 112, 523-532.

De Andrade, M.L. (1995) The ant genus Aphaenogaster in Dominican and Mexican amber (Amber Collection Stuttgart: Hymenoptera, Formicidae. IX: Pheidolini). Stuttgarter Beiträge zur Naturkunde. Serie B (Geologie und Paläontologie), 223, 1-11.

De Andrade, M.L. (2003) First descriptions of two new amber species of Cyphomyrmex from Mexico and the Dominican Republic (Hymenoptera: Formicidae). Beiträge zur Entomologie, 53, 131-139.

De Andrade, M.L. \& Baroni Urbani, C. (2003) The Baltic amber ant genus Bradoponera 
(Hymenoptera: Formicidae), with description of two new species and a reassessment of the Proceratiini genera. Revue Suisse de Zoologie, 110, 913-938.

Degnan, P.H., Lazarus, A.B.; Brock, C.D. \& Wernegreen, J.J. (2004) Host-symbiont stability and fast evolutionary rates in an ant-bacterium association: cospeciation of Camponotus species and their endosymbionts, Candidatus Blochmannia. Systematic Biology, 53, 95-110.

Dejean, A. (1985b) Étude éco-éthologique de la prédation chez les fourmis du genre Smithistruma (Formicidae - Myrmicinae - Dacetini). II. Attraction des proies principales (collemboles). Insectes Sociaux, 32, 158-172.

Dejean, A. (1987 (“1986”)) Étude du comportement de prédation dans le genre Strumigenys (Formicidae - Myrmicinae). Insectes Sociaux, 33, 388-405.

Delabie, J.H.C. \& Blard, F. (2002) The tramp ant Hypoponera punctatissima (Roger) (Hymenoptera: Formicidae: Ponerinae): new records from the southern hemisphere. Neotropical Entomology, 31, 149-151.

De Vita, J. (1979) Mechanisms of interference and foraging amoung colonies of the harvester ant Pogonomyrmex californicus in the Mojave Desert. Ecology, 60, 729-737.

Deyrup, M. (1991) Technomyrmex albipes, a new exotic ant in Florida (Hymenoptera: Formicidae). Florida Entomologist, 74, 147-148.

Deyrup, M. \& Cover, S. (2004) A new species of the ant genus Leptothorax from Florida, with a key to the Leptothorax of the southeast (Hymenoptera: Formicidae). Florida Entomologist, 87, 51-59.

Diniz-Filho, J.A.F. \& Fowler, H.G. (1998) Honey ants (genus Myrmecocystus) macroecology: effect of spatial patterns on the relationship between worker body size and geographic range size. Environmental Entomology, 27, 1094-1101.

Disney, R.H.L. (1982) Three new species of scuttle-fly (Diptera: Phoridae) that parasitize ants (Hymenoptera: Formicidae) in North America. Journal of Zoology (London), 197, 473-481.

Dlussky, G.M. (1967a) Ants of the genus Formica (Hymenoptera, Formicidae, g. Formica). [In Russian.] Nauka Publishing House, Moskva, 236 pp.

Douwes, P. \& Stille, B. (1987) The use of enzyme electrophoresis in Leptothorax classification. In: Eder, J. \& Rembold, H. (Eds.), Chemistry and biology of social insects. Verlag J. Peperny, München, pp. 29-30.

DuBois, M.B. (1986) A revision of the native New World species of the ant genus Monomorium (minimum group) (Hymenoptera: Formicidae). University of Kansas Science Bulletin, 53, 65119.

DuBois, M.B. (1998) A revision of the ant genus Stenamma in the Palaearctic and Oriental regions (Hymenoptera: Formicidae: Myrmicinae). Sociobiology, 32, 193-403.

DuBois, M.B. (2000) Monomorium minimum species group: gyne number and longevity (Hymenoptera: Formicidae). Entomological News, 111, 13-20.

Duffield, R.M., Blum, M.S. \& Wheeler, J.W. (1976) Alkyl pyrazine alarm pheromones in primitive ants with small colonial units. Comparative Biochemistry and Physiology. B. Comparative Biochemistry, 54, 439-440.

Duncan, F.D. \& Lighton, J.R.B. (1994a) Water relations in nocturnal and diurnal foragers of the desert honeypot ant Myrmecocystus: implications for colony-level selection. Journal of Experimental Zoology, 270, 350-359.

Duncan, F.D. \& Lighton, J.R.B. (1994b) The burden within: the energy cost of load carriage in the honeypot ant, Myrmecocystus. Physiological Zoology, 67, 190-203.

Emery, C. (1869b) Enumerazione dei formicidi che rinvengonsi nei contorni di Napoli con descrizioni di specie nuove o meno conosciute. Annali dell'Accademia degli Aspiranti Naturalisti. Secunda Era, 2, 1-26.

Emery, C. (1893k) Beiträge zur Kenntniss der nordamerikanischen Ameisenfauna. Zoologische Jahrbücher. Abteilung für Systematik, Geographie und Biologie der Tiere, 7, 633-682. 
Emery, C. (1894b) Mission scientifique de M. Ch. Alluaud aux îles Séchelles (mars, avril, mai 1892). 2e mémoire. Formicides. Annales de la Société Entomologique de France, 63, 67-72.

Emery, C. (1894d) Studi sulle formiche della fauna neotropica. VI-XVI. Bullettino della Società Entomologica Italiana, 26, 137-241.

Emery, C. (1895d) Beiträge zur Kenntniss der nordamerikanischen Ameisenfauna. (Schluss). Zoologische Jahrbücher. Abteilung für Systematik, Geographie und Biologie der Tiere, 8, 257-360.

Emery, C. (1906c ("1905”)) Studi sulle formiche della fauna neotropica. XXVI. Bullettino della Società Entomologica Italiana, 37, 107-194.

Emery, C. (1921c) Hymenoptera. Fam. Formicidae. Subfam. Myrmicinae. [part] Genera Insectorum, 174A, 1-94 + 7 plates.

Evans, J.D. (1995) Relatedness threshold for the production of female sexuals in colonies of a polygynous ant, Myrmica tahoensis, as revealed by microsatellite DNA analysis. Proceedings of the National Academy of Sciences of the United States of America, 92, 6514-6517.

Evans, J.D. (1996a) Queen longevity, queen adoption, and posthumous indirect fitness in the facultatively polygynous ant Myrmica tahoensis. Behavioral Ecology and Sociobiology, 39, 275284.

Evans, J.D. (1996b) Temporal and spatial variation in reproduction in the facultatively polygynous ant Myrmica tahoensis (Hymenoptera: Formicidae). Insectes Sociaux, 43, 309-317.

Fabricius, J. C. (1782 (“1781”)) Species insectorum exhibentes eorum differentias specificas, synonyma, auctorum loca natalia, metamorphosin adiectis observationibus, descriptionibus. Tome I. C. E. Bohn, Hamburgi et Kilonii [= Hamburg and Kiel], 552 pp.

Fabricius, J.C. (1793) Entomologia systematica emendata et aucta. Secundum classes, ordines, genera, species, adjectis synonimis, locis observationibus, descriptionibus. Tome 2. C. G. Proft, Hafniae [= Copenhagen], 519 pp.

Fales, H.M., Blum, M.S., Crewe, R.M. \& Brand, J.M. (1972) Alarm pheromones in the genus Manica derived from the mandibular gland. Journal of Insect Physiology, 18, 1077-1088.

Fernández, F. (2005) Two new South American species of Monomorium Mayr with taxonomic notes on the genus. Memoirs of the American Entomological Institute, in press.

Foerster, A. (1850a) Hymenopterologische Studien. 1. Formicariae. Ernst Ter Meer, Aachen, 74 pp.

Foitzik, S., Heinze, J., Oberstadt, B. \& Herbers, J.M. (2002) Mate guarding and alternative reproductive tactics in the ant Hypoponera opacior. Animal Behaviour, 63, 597-604.

Fontenla, J.L. (2000) The genus Prenolepis Mayr, 1861 (Formicidae) in the Greater Antilles, with an outline of phylogenetic relationships. Caribbean Journal of Science, 36, 76-86.

Forel, A. (1886b) Espèces nouvelles de fourmis américaines. Annales de la Société Entomologique de Belgique, 30, xxxviii-xlix.

Forel, A. (1890b) Fourmis de Tunisie et de l'Algérie orientale. Annales de la Société Entomologique de Belgique, 34, lxi-lxxvi.

Forel, A. (1893f) Nouvelles fourmis d'Australie et des Canaries. Annales de la Société Entomologique de Belgique, 37, 454-466.

Forel, A. (1893j) Formicides de l'Antille St. Vincent, récoltées par Mons. H. H. Smith. Transactions of the Entomological Society of London, 1893, 333-418.

Forel, A. (1899a) Heterogyna (Formicidae). Fauna Hawaiiensis, 1, 116-122.

Forel, A. (1900h) Fourmis du Japon. Nids en toile. Strongylognathus Huberi et voisins. Fourmilière triple. Cyphomyrmex Wheeleri. Fourmis importées. Mitteilungen der Schweizerischen Entomologischen Gesellschaft, 10, 267-287.

Forel, A. (1901j) Variétés myrmécologiques. Annales de la Société Entomologique de Belgique, 45, 334-382.

Forel, A. (19011) Fourmis termitophages, Lestobiose, Atta tardigrada, sous-genres d'Euponera. Annales de la Société Entomologique de Belgique, 45, 389-398.

Forel, A. (1904b) Fourmis de British Columbia récoltées par M. Ed. Whymper. Annales de la 
Société Entomologique de Belgique, 48, 152-155.

Forel, A. (1908c) Fourmis de Costa-Rica récoltées par M. Paul Biolley. Bulletin de la Société Vaudoise des Sciences Naturelles, 44, 35-72.

Forel, A. (1914c) Einige amerikanische Ameisen. Deutsche Entomologische Zeitschrift, 1914, 615620.

Forel, A. (1914d) Formicides d'Afrique et d'Amérique nouveaux ou peu connus. Bulletin de la Société Vaudoise des Sciences Naturelles, 50, 211-288.

Francoeur, A. (1973) Révision taxonomique des espèces néarctiques du groupe fusca, genre Formica (Formicidae, Hymenoptera). Mémoires de la Société Entomologique du Québec, 3, 1316.

Francoeur, A. (1986b) Deux nouvelles fourmis néarctiques: Leptothorax retractus et L. sphagnicolus (Formicidae, Hymenoptera). Canadian Entomologist, 118, 1151-1164.

Francoeur, A. (2005) Myrmica punctiventris and M. crassirugis species groups in the Nearctic Region. Memoirs of the American Entomological Institute, in press.

Francoeur, A., Loiselle, R. \& Buschinger, A. (1985) Biosystématique de la tribu Leptothoracini (Formicidae, Hymenoptera). 1. Le genre Formicoxenus dans la région holarctique. Naturaliste Canadien (Québec), 112, 343-403.

Francoeur, A. \& Snelling, R.R. (1979) Notes for a revision of the ant genus Formica. 2. Reidentifications for some specimens from the T. W. Cook collection and new distribution data (Hymenoptera: Formicidae). Contributions in Science (Los Angeles), 309, 1-7.

Gadau, J., Brady, S.G. \& Ward, P.S. (1999) Systematics, distribution and ecology of an endemic California Camponotus quercicola (Hymenoptera: Formicidae). Annals of the Entomological Society of America, 92, 514-522.

Gamboa, G.J. (1975) Foraging and leaf-cutting of the desert gardening ant Acromyrmex versicolor versicolor (Pergande) (Hymenoptera: Formicidae). Oecologia (Berlin), 20, 103-110.

Gamboa, G.J. (1976) Effects of temperature on the surface activity of the desert leaf-cutter ant, Acromyrmex versicolor versicolor (Pergande) (Hymenoptera: Formicidae). American Midland Naturalist, 95, 485-491.

Gordon, D.M. (1999) Ants at work. Free Press, New York, x + 182 pp.

Gordon, D.M., Moses, L., Falkovitz-Halpern, M. \& Wong, E. H. (2001) Effect of weather on infestation of buildings by the invasive Argentine ant, Linepithema humile (Hymenoptera: Formicidae). American Midland Naturalist, 146, 321-328.

Gorman, J.S.T., Jones, T.H., Spande, T.F., Snelling, R.R., Torres, J.A. \& Garraffo, H.M. (1998) 3Hexyl-5-methylindolizidine isomers from thief ants, Solenopsis (Diplorhoptrum) species. Journal of Chemical Ecology, 24, 933-943.

Gösswald, K. (1989) Die Waldameise. Band 1. Biologische Grundlagen, Ökologie und Verhalten. AULA-Verlag, Wiesbaden, xi +660 pp.

Gösswald, K. (1990) Die Waldameise. Band 2. Die Waldameise im Ökosystem Wald, ihr Nutzen und ihre Hege. AULA-Verlag, Wiesbaden, $\mathrm{x}+510 \mathrm{pp}$.

Gotwald, W.H., Jr. (1995) Army ants: the biology of social predation. Cornell University Press, Ithaca, New York, xviii + 302 pp.

Greenberg, L., Aliabadi, A., McElfresh, J.S., Topoff, H. \& Millar, J.G. (2004) Sex pheromone of queens of the slave-making ant, Polyergus breviceps. Journal of Chemical Ecology, 30, 12971303.

Gregg, R.E. (1950) A new species of Pheidole from the Southwest. Journal of the New York Entomological Society, 58, 89-93.

Gregg, R.E. (1955a) A new species of ant belonging to the Pheidole pilifera complex (Hymenoptera: Formicidae). Psyche (Cambridge), 62, 19-28.

Gregg, R.E. (1959 ("1958”)) Key to the species of Pheidole (Hymenoptera: Formicidae) in the United States. Journal of the New York Entomological Society, 66, 7-48. 
Gregg, R.E. (1969b) New species of Pheidole from Pacific Coast islands (Hymenoptera: Formicidae). Entomological News, 80, 93-101.

Groark, K.P. (2001) Taxonomic identity of "hallucinogenic" harvester ant (Pogonomyrmex californicus) confirmed. Journal of Ethnobiology, 21, 133-144.

Gulmahamad, H. (1995) The genus Liometopum Mayr (Hymenoptera: Formicidae) in California, with notes on nest architecture and structural importance. Pan-Pacific Entomologist, 71, 8286.

Gulmahamad, H. (1997) Ecological studies on Cardiocondyla ectopia Snelling (Hymenoptera: Formicidae) in southern California. Pan-Pacific Entomologist, 73, 21-27.

Haldeman, S.S. (1844) Descriptions of insects, presumed to be undescribed. Proceedings of the Academy of Natural Sciences of Philadelphia, 2, 53-55.

Hansen, L.D. \& Akre, R. D. (1985) Biology of carpenter ants in Washington State (Hymenoptera: Formicidae: Camponotus). Melanderia, 43, i-v, 1-61.

Hasegawa, E. (1998) Phylogeny and host-parasite relationships in social parasitism in Lasius ants. Entomological Science, 1, 133-135.

Hasegawa, E., Tinaut, A. \& Ruano, F. (2002) Molecular phylogeny of two slave-making ants: Rossomyrmex and Polyergus (Hymenoptera: Formicidae). Annales Zoologici Fennici, 39, 267271.

Haskins, C.P. (1928) Notes on the behavior and habits of Stigmatomma pallipes Haldeman. Journal of the New York Entomological Society, 36, 179-184.

Heinze, J. (1989b) A biochemical approach toward the systematics of the Leptothorax "muscorum" group in North America (Hymenoptera: Formicidae). Biochemical Systematics and Ecology, $17,595-601$.

Heinze, J. (1991) Biochemical studies on the relationship between socially parasitic ants and their hosts. Biochemical Systematics and Ecology, 19, 195-206.

Heinze, J. (1998 (“1995”)) The origin of workerless parasites in Leptothorax (s. str) (Hymenoptera: Formicidae). Psyche (Cambridge), 102, 195-214.

Heinze, J. (1999) Male polymorphism in the ant species Cardiocondyla minutior (Hymenoptera: Formicidae). Entomologia Generalis, 23, 251-258.

Heinze, J., Böttcher, A. \& Cremer, S. (2004) Production of winged and wingless males in the ant, Cardiocondyla minutior. Insectes Sociaux, 51, 275-278.

Heinze, J. \& Hölldobler, B. (1993b) Fighting for a harem of queens: physiology of reproduction in Cardiocondyla male ants. Proceedings of the National Academy of Sciences of the United States of America, 90, 8412-8414.

Heinze, J., Stahl, M. \& Hölldobler, B. (1996) Ecophysiology of hibernation in boreal Leptothorax ants (Hymenoptera: Formicidae). Écoscience, 3, 429-435.

Heller, N.E. (2004) Colony structure in introduced and native populations of the invasive Argentine ant, Linepithema humile. Insectes Sociaux, 51, 378-386.

Helms Cahan, S. (2001) Ecological variation across a transition in colony-founding behavior in the ant Messor pergandei. Oecologia (Berlin), 129, 629-635.

Helms Cahan, S., Parker, J.D., Rissing, S.W., Johnons, R.A., Polony, T.S., Weiser, M.D. \& Smith, D.R. (2002) Extreme genetic differences between queens and workers in hybridizing Pogonomyrmex harvester ants. Proceedings of the Royal Entomological Society of London. Series B, 269, 1871-1877.

Heterick, B.E. (2001) Revision of the Australian ants of the genus Monomorium (Hymenoptera: Formicidae). Invertebrate Taxonomy, 15, 353-459.

Hickman, J.C. (Ed.) (1993) The Jepson manual. Higher plants of California. University of California Press, Berkeley, xvii + 1400 pp.

Hobbs, R. J. (1985) Harvester ant foraging and plant species distribution in annual grassland. Oecologia (Berlin), 67, 519-523. 
Hölldobler, B. (1976a) Recruitment behavior, home range orientation and territoriality in harvester ants, Pogonomyrmex. Behavioral Ecology and Sociobiology, 1, 3-44.

Hölldobler, B. (1976b) Tournaments and slavery in a desert ant. Science (Washington, D. C.), 192, 912-914.

Hölldobler, B. (1976c) The behavioral ecology of mating in harvester ants (Hymenoptera: Formicidae: Pogonomyrmex). Behavioral Ecology and Sociobiology, 1, 405-423.

Hölldobler, B. (1985 ("1984”)) A new exocrine gland in the slave raiding ant genus Polyergus. Psyche (Cambridge), 91, 225-235.

Hölldobler, B. (1986) Food robbing in ants, a form of interference competition. Oecologia (Berlin), $69,12-15$.

Holldobler, B. \& Carlin, N.F. (1990 (“1989”)) Colony founding, queen control and worker reproduction in the ant Aphaenogaster (Novomessor) cockerelli (Hymenoptera: Formicidae). Psyche (Cambridge), 96, 131-151.

Hölldobler, B., Oldham, N.J., Morgan, E.D. \& König, W.A. (1995) Recruitment pheromones in the ants Aphaenogaster albisetosus and A. cockerelli (Hymenoptera: Formicidae). Journal of Insect Physiology, 41, 739-744.

Holway, D.A. (1998) Factors governing rate of invasion: a natural experiment using Argentine ants. Oecologia (Berlin), 115, 206-212.

Holway, D.A. (1999) Competitive mechanisms underlying the displacement of native ants by the invasive Argentine ant. Ecology, 80, 238-251.

Holway, D.A. \& Suarez, A. V. (2004) Colony-structure variation and interspecific competitive ability in the invasive Argentine ant. Oecologia (Berlin), 138, 216-222.

Holway, D.A., Suarez, A.V. \& Case, T.J. (1998) Loss of intraspecific aggression in the success of a widespread social insect. Science (Washington, D. C), 282, 949-952.

Holway, D.A., Suarez, A.V. \& Case, T.J. (2002) Role of abiotic factors in governing susceptibility to invasion: a test with Argentine ants. Ecology, 83, 1610-1619.

Human, K.G. \& Gordon, D.M. (1996) Exploitation and interference competition between the invasive Argentine ant, Linepithema humile, and native ant species. Oecologia (Berlin), 105, 405412.

Human, K.G. \& Gordon, D.M. (1997) Effects of Argentine ants on invertebrate biodiversity in northern California. Conservation Biology, 11, 1242-1248.

Hunt, J.H. \& Snelling, R.R. (1975) A checklist of the ants of Arizona. Journal of the Arizona Academy of Science, 10, 20-23.

Ingram, K.K. \& Gordon, D.M. (2003) Genetic analysis of dispersal dynamics in an invading population of Argentine ants. Ecology, 84, 2832-2842.

Janda, M., Folková, D. \& Zrzavý, J. (2004) Phylogeny of Lasius ants based on mitochondrial DNA and morphology, and the evolution of social parasitism in the Lasiini (Hymenoptera: Formicidae). Molecular Phylogenetics and Evolution, 33, 595-614.

Johnson, C. (1989b) Taxonomy and diagnosis of Conomyrma insana (Buckley) and C. flava (McCook) (Hymenoptera: Formicidae). Insecta Mundi, 3, 179-194.

Johnson, R.A. (2000a) Seed-harvester ants (Hymenoptera: Formicidae) of North America: an overview of ecology and biogeography. Sociobiology, 36, 89-122 + 83-88.

Johnson, R.A. (2000b) Seed harvesting species of Pheidole (Hymenoptera: Formicidae). Sociobiology, 36, 597.

Johnson, R.A. (2001) Biogeography and community structure of North American seed-harvesting ants. Annual Review of Entomology, 46, 1-29.

Johnson, R.A. \& Rissing, S.W. (1993) Breeding biology of the desert leaf-cutter ant Acromyrmex versicolor (Pergande) (Hymenoptera: Formicidae). Journal of the Kansas Entomological Society, 66, 127-128.

Johnson, R.A. \& Ward, P.S. (2002) Biogeography and endemism of ants (Hymenoptera: Formi- 
cidae) in Baja California, Mexico: a first overview. Journal of Biogeography, 29, 1009-1026.

Jones, S.R. \& Phillips, S.A., Jr. (1989) Superiority of Aphaenogaster occidentalis in confrontations with Solenopsis invicta (Hymenoptera Formicidae). Entomological News, 100, 173-175.

Jones, T.H., Blum, M.S. \& Fales, H.M. (1982a) Ant venom alkaloids from Solenopsis and Monomorium species. Recent developments. Tetrahedron, 38, 1949-1958.

Jones, T.H., Blum, M.S., Howard, R.W., McDaniel, C.A., Fales, H.M., DuBois, M.B. \& Torres, J. (1982b) Venom chemistry of ants in the genus Monomorium. Journal of Chemical Ecology, 8, 285-300.

Jourdan, H. (1997) Threats on Pacific islands: the spread of the tramp ant Wasmannia auropunctata (Hymenoptera: Formicidae). Pacific Conservation Biology, 3, 61-64.

Julian, G.E. \& Fewell, J.H. (2004) Genetic variation and task specialization in the desert leaf-cutter ant, Acromyrmex versicolor. Animal Behaviour, 68, 1-8.

Kay, C.A.R. \& Whitford, W.G. (1978) Critical thermal limits of desert honey ants: possible ecological implications. Physiological Zoology, 51, 206-213.

Kempf, W.W. (1960a) Estudo sôbre Pseudomyrmex I. (Hymenoptera: Formicidae). Revista Brasileira de Entomologia, 9, 5-32.

Kempf, W.W. (1964d) A revision of the Neotropical fungus-growing ants of the genus Cyphomyrmex Mayr. Part I: Group of strigatus Mayr (Hym., Formicidae). Studia Entomologica, 7, 1-44.

Kempf, W.W. (1966 ("1965”)) A revision of the Neotropical fungus-growing ants of the genus Cyphomyrmex Mayr. Part II: Group of rimosus (Spinola) (Hym., Formicidae). Studia Entomologica, 8, 161-200.

Kistner, D.H., Jensen, E.A. \& Jacobson, H.R. (2002) A new genus and two new species of myrmecophilous Staphylinidae found with Liometopum in California (Coleoptera; Hymenoptera: Formicidae). Sociobiology, 39, 291-305.

Knight, R.L. \& Rust, M.K. (1990) The urban ants of California with distribution notes of imported species. Southwestern Entomologist, 15, 167-178.

Knudtson, B. K. (1978) Intrapopulation genetic similarity in Pogonomyrmex californicus (Buckley) (Hymenoptera: Formicidae). Journal of the Tennessee Academy of Science, 53, 78-80.

Korzukhin, M.D., Porter, S.D., Thompson, L.C. \& Wiley, S. (2001) Modeling temperature-dependent range limits for the fire ant Solenopsis invicta (Hymenoptera: Formicidae) in the United States. Environmental Entomology, 30, 645-655.

Kronauer, D.J.C., Gadau, J. \& Hölldobler, B. (2003) Genetic evidence for intra- and interspecific slavery in honey ants (genus Myrmecocystus). Proceedings of the Royal Entomological Society of London. Series B, 270, 805-810.

Kronauer, D.J.C., Hölldobler, B. \& Gadau, J. (2004) Phylogenetics of the New World honey ants (genus Myrmecocystus) estimated from mitochondrial DNA sequences. Molecular Phylogenetics and Evolution, 32, 416-421.

Kugler, C. (1994) A revision of the ant genus Rogeria with description of the sting apparatus (Hymenoptera: Formicidae). Journal of Hymenoptera Research, 3, 17-89.

Kugler, J. (1984 ("1983”)) The males of Cardiocondyla Emery (Hymenoptera: Formicidae) with the description of the winged male of Cardiocondyla wroughtoni (Forel). Israel Journal of Entomology, 17, 1-21.

Kusnezov, N. (1951e) El género Pogonomyrmex Mayr (Hym., Formicidae). Acta Zoologica Lilloana, 11, 227-333.

Lacau, S. \& Delabie, J.H.C. (2002) Description de trois nouvelles espèces d'Amblyopone avec quelques notes biogéographiques sur le genre au Brésil (Formicidae, Ponerinae). Bulletin de la Société Entomologique de France, 107, 33-41.

Langen, T.A., Tripet, F. \& Nonacs, P. (2000) The red and the black: habituation and the dear-enemy phenomenon in two desert Pheidole ants. Behavioral Ecology and Sociobiology, 48, 285-292. 
Latreille, P.A. (1802a) Histoire naturelle des fourmis, et recueil de mémoires et d'observations sur les abeilles, les araignées, les faucheurs, et autres insectes. Impr. Crapelet (chez T. Barrois), Paris, xvi $+445 \mathrm{pp}$.

Lattke, J.E. (1991d) Studies of neotropical Amblyopone Erichson (Hymenoptera: Formicidae). Contributions in Science (Los Angeles), 428, 1-7.

Le Breton, J., Delabie, J.H.C., Chazeau, J., Dejean, A. \& Jourdan, H. (2004) Experimental evidence of large-scale unicoloniality in the tramp ant Wasmannia auropunctata (Roger). Journal of Insect Behavior, 17, 263-271.

Lei, S. A. (2000) Potential impacts of Pogonomyrmex rugosus on Larrea tridentata in southern California. Bulletin of the Southern California Academy of Sciences, 99, 174-176.

Lenoir, A., Malosse, C. \& Yamaoka, R. (1997) Chemical mimicry between parasitic ants of the genus Formicoxenus and their host Myrmica (Hymenoptera, Formicidae). Biochemical Systematics and Ecology, 25, 379-389.

Linnaeus, C. (1758) Systema naturae per regna tria naturae, secundum classes, ordines, genera, species, cum characteribus, differentiis, synonymis, locis. Tomus I. Editio decima, reformata. L. Salvii, Holmiae [= Stockholm], 824 pp.

Lloyd, H.A., Blum, M.S., Snelling, R.R. \& Evans, S.L. (1989) Chemistry of mandibular and Dufour's gland secretions of ants in genus Myrmecocystus. Journal of Chemical Ecology, 15, 2589-2599.

Loiselle, R., Francouer, A., Fischer, K. \& Buschinger, A. (1990) Variations and taxonomic significance of the chromosome numbers in the Nearctic species of the genus Leptothorax (s.s) (Formicidae: Hymenoptera). Caryologia, 43, 321-334.

Longcore, T. (2003) Terrestrial arthropods as indicators of ecological restoration success in coastal sage scrub (California, U.S.A.). Restoration Ecology, 11, 397-409.

Longhurst, C., Baker, R. \& Howse, P.E. (1980) A comparative analysis of mandibular gland secretions in the ant tribe Tetramoriini. Insect Biochemistry, 10, 107-112.

Longino, J.T. (2003A) The Crematogaster (Hymenoptera, Formicidae, Myrmicinae) of Costa Rica. Zootaxa, 151, 1-150.

Longino, J.T. \& Fernández, F. (2005) A taxonomic review of the ant genus Wasmannia. Memoirs of the American Entomological Institute, in press.

Lubin, Y.D. (1984) Changes in the native fauna of the Galápagos Islands following invasion by the little red fire ant, Wasmannia auropunctata. Biological Journal of the Linnean Society, 21, 229-242.

Lynch, J.F., Balinsky, E.D. \& Vail, S.G. (1980) Foraging patterns in three sympatric forest ant species, Prenolepis imparis, Paratrechina melanderi and Aphaenogaster rudis (Hymenoptera: Formicidae). Ecological Entomology, 5, 353-371.

MacArthur, A.A. (2005) A key to Camponotus Mayr of Australia. Memoirs of the American Entomological Institute, in press.

MacKay, W.P. (1980) A new harvester ant from the mountains of southern California (Hymenoptera: Formicidae). Southwestern Naturalist, 25, 151-156.

MacKay, W.P. (1981) A comparison of the nest phenologies of three species of Pogonomyrmex harvester ants (Hymenoptera: Formicidae). Psyche (Cambridge), 88, 25-74.

MacKay, W.P. (1982) An altitudinal comparison of oxygen consumption rates in three species of Pogonomyrmex harvester ants (Hymenoptera: Formicidae). Physiological Zoology, 55, 367377.

MacKay, W.P. (1995) New distributional records for the ant genus Cardiocondyla in the New World (Hymenoptera: Formicidae). Pan-Pacific Entomologist, 71, 169-172.

MacKay, W.P. (1998) A remarkable new species of Paratrechina (Hymenoptera: Formicidae) from the state of Colima, Mexico. Pan-Pacific Entomologist, 74, 99-101.

Mackay, W.P. (2000) A review of the New World ants of the subgenus Myrafant, (genus Leptotho- 
rax) (Hymenoptera: Formicidae). Sociobiology, 36, 265-444.

MacKay, W.P. \& MacKay, E.E. (1989) Diurnal foraging patterns of Pogonomyrmex harvester ants (Hymenoptera: Formicidae). Southwestern Naturalist, 34, 213-218.

Mackay, W. \& Mackay, E. (2002) The ants of New Mexico (Hymenoptera: Formicidae). Edwin Mellen Press, Lewiston, New York, 400 pp.

Mallis, A. (1941) A list of the ants of California with notes on their habits and distribution. Bulletin of the Southern California Academy of Sciences, 40, 61-100.

Martinez, M.J. (1992) A new ant introduction for North America: Pheidole teneriffana (Forel) (Hymenoptera: Formicidae). Pan-Pacific Entomologist, 68, 153-154.

Martinez, M.J. (1993) The first field record for the ant Tetramorium bicarinatum Nylander (Hymenoptera: Formicidae) in California. Pan-Pacific Entomologist, 69, 272-273.

Martinez, M.J. (1995) The first record of mixed nests of Conomyrma bicolor (Wheeler) and Conomyrma insana (Buckley) (Hymenoptera: Formicidae). Pan-Pacific Entomologist, 71, 252.

Martinez, M.J. (1996) The first North American record for the ant Pheidole fervens Fr. Smith (Hymenoptera: Formicidae). Pan-Pacific Entomologist, 72, 171-172.

Martinez, M.J. (1997) The first record of the ant Pheidole moerens Wheeler from the western United States (Hymenoptera Formicidae). Pan-Pacific Entomologist, 73, 46.

Masuko, K. (1995 (“1994”)) Specialized predation on oribatid mites by two species of the ant genus Myrmecina (Hymenoptera: Formicidae). Psyche (Cambridge), 101, 159-173.

Mayr, G. (1868b) Formicidae novae Americanae collectae a Prof. P. de Strobel. Annuario della Società dei Naturalisti e Matematici, Modena, 3, 161-178.

Mayr, G. (1868c) Die Ameisen des baltischen Bernsteins. Beiträge zur Naturkunde Preussens, 1, 1102.

Mayr, G. (1870b) Neue Formiciden. Verhandlungen der Kaiserlich-Königlichen Zoologisch-Botanischen Gesellschaft in Wien, 20, 939-996.

Mayr, G. (1886d) Die Formiciden der Vereinigten Staaten von Nordamerika. Verhandlungen der Kaiserlich-Königlichen Zoologisch-Botanischen Gesellschaft in Wien, 36, 419-464.

Mayr, G. (1887) Südamerikanische Formiciden. Verhandlungen der Kaiserlich-Königlichen Zoologisch-Botanischen Gesellschaft in Wien, 37, 511-632.

McCook, H.C. (1880 (“1879”)) Formicariae. In: Comstock, J.H., Report upon cotton insects. Government Printing Office, Washington, D.C., pp. 182-189.

Meissner, H.E. \& Silverman, J. (2001) Effects of aromatic cedar mulch on the Argentine ant and the odorous house ant (Hymenoptera: Formicidae). Journal of Economic Entomology, 94, 15261531.

Merickel, F.W. \& Clark, W.H. (1994) Tetramorium caespitum (Linnaeus) and Liometopum luctuosum W.M. Wheeler (Hymenoptera: Formicidae): new state records for Idaho and Oregon, with notes on their natural history. Pan-Pacific Entomologist, 70, 148-158.

Möglich, M. (1979) Tandem calling pheromone in the genus Leptothorax (Hymenoptera: Formicidae): behavioral analysis of specificity. Journal of Chemical Ecology, 5, 35-52.

Morisita, M., Kubota, M., Onoyama, K., Ogata, K., Terayama, M., Kondoh, M. \& Imai, H. T. (1989) A guide for the identification of Japanese ants. I. Ponerinae, Cerapachyinae, Pseudomyrmecinae, Dorylinae, and Leptanillinae (Hymenoptera: Formicidae). [In Japanese.] Myrmecological Society of Japan, Tokyo, 42 pp.

Morisita, M., Kubota, M., Onoyama, K., Ogata, K., Terayama, M., Yamauchi, K., Sonobe, R., Kondoh, M. \& Imai, H. T. (1991) A guide for the identification of Japanese ants. II. Dolichoderinae and Formicinae (Hymenoptera: Formicidae). [In Japanese.] Myrmecological Society of Japan, Tokyo, 56 pp.

Morisita, M., Kubota, M., Onoyama, K., Ogata, K., Terayama, M., Yamauchi, K., Sonobe, R., Yamane, S., Kondoh, M. \& Imai, H.T. (1992) A guide for the identification of Japanese ants. III. Myrmicinae and supplement to Leptanillinae. (Hymenoptera: Formicidae). [In Japanese.] 
Myrmecological Society of Japan, Tokyo, 94 pp.

Morrison, L.W. (2002) Long-term impacts of an arthropod-community invasion by the imported fire ant, Solenopsis invicta. Ecology, 83, 2337-2345.

Mueller, U.G., Schultz, T.R., Currie, C.R., Adams, R.M.M. \& Malloch, D. (2001) The origin of the attine ant-fungus mutualism. Quarterly Review of Biology, 76, 169-197.

Murakami, T., Ohkawara, K. \& Higashi, S. (2002) Morphology and developmental plasticity of reproductive females in Myrmecina nipponica (Hymenoptera: Formicidae) Annals of the Entomological Society of America, 95, 577-582.

Newell, W. \& Barber, T.C. (1913) The Argentine ant. United States Department of Agriculture. Bureau of Entomology. Bulletin, 122, 1-98.

Nylander, W. (1846a) Adnotationes in monographiam formicarum borealium Europae. Acta Societatis Scientiarum Fennicae, 2, 875-944.

Nylander, W. (1846b) Additamentum adnotationum in monographiam formicarum borealium Europae. Acta Societatis Scientiarum Fennicae, 2, 1041-1062.

O’Dowd, D. J. \& Hay, M. E. (1980) Mutualism between harvester ants and a desert ephemeral: seed escape from rodents. Ecology, 61, 531-540.

Ogata, K., Murai, K., Yamauchi, K. \& Tsuji, K. (1996) Size differentiation of copulatory organs between winged and wingless reproductives in the ant Technomyrmex albipes. Naturwissenschaften, 83, 331-333.

O'Keefe, S.T., Cook, J.L., Dudek, T., Wunneburger, D.F., Guzman, M.D., Coulson, R.N. \& Vinson, S.B. (2000) The distribution of Texas ants. Southwestern Entomologist Supplement, 22, 1-92.

Olsen, O.W. (1934) Notes on the North American harvesting ants of the genus Pogonomyrmex Mayr. Bulletin of the Museum of Comparative Zoology, 77, 493-514.

Onoyama, K. \& Yoshimura, M. (2002) The ants of the genus Proceratium (Hymenoptera: Formicidae) in Japan. Entomological Science, 5, 29-49.

Page, R.E., Jr. (1982) Polyandry in Brachymyrmex depilis Emery (Hymenoptera: Formicidae). PanPacific Entomologist, 58, 258.

Parker, J.D. \& Rissing, S.W. (2002) Molecular evidence for the origin of workerless social parasites in the ant genus Pogonomyrmex. Evolution, 56, 2017-2028.

Pergande, T. (1893) On a collection of Formicidae from Lower California and Sonora, Mexico. Proceedings of the California Academy of Sciences, (2)4, 26-36.

Pergande, T. (1896) Mexican Formicidae. Proceedings of the California Academy of Sciences, (2)5, $858-896$.

Peters, J.M. (1997) Microsatellite loci for Pseudomyrmex pallidus (Hymenoptera: Formicidae). Molecular Ecology, 6, 887-888.

Porter, S.D. \& Savignano, D.A. (1990) Invasion of polygyne fire ants decimates native ants and disrupts arthropod community. Ecology, 71, 2095-2106.

Provancher, L. (1881b) Faune canadienne. (Continué de la page 333) Naturaliste Canadien (Québec), 12, 353-362.

Radchenko, A.G. (1994a) Taxonomic structure of the ant genus Myrmica (Hymenoptera, Formicidae) of Eurasia. Report 1. [In Russian.] Zoologicheskii Zhurnal, 73(6), 39-51.

Radchenko, A.G. (1994d) Identification table for ants of the genus Myrmica (Hymenoptera, Formicidae) from central and eastern Palearctic. [In Russian.] Zoologicheskii Zhurnal, 73(7-8), 130_ 145.

Reichardt, A.K. \& Wheeler, D.E. (1996) Multiple mating in the ant Acromyrmex versicolor: a case of female control. Behavioral Ecology and Sociobiology, 38, 219-225.

Rissing, S.W. (1984) Replete caste production and allometry of workers in the honey ant, Myrmecocystus mexicanus Wesmael (Hymenoptera: Formicidae). Journal of the Kansas Entomological Society, 57, 347-350.

Rissing, S.W., Johnson, R.A. \& Pollock, G.B. (1986) Natal nest distribution and pleometrosis in the 
desert leaf-cutter ant Acromyrmex versicolor (Pergnade) (Hymenoptera: Formicidae). Psyche (Cambridge), 93, 177-186.

Rissing, S.W., Pollock, G.B. \& Higgins, M.R. (1989) Foraging specialization without relatedness or dominance among co-founding ant queens. Nature (London), 338, 420-422.

Rissing, S.W. \& Wheeler, J. (1976) Foraging responses of Veromessor pergandei to changes in seed production (Hymenoptera: Formicidae). Pan-Pacific Entomologist, 52, 63-72.

Roger, J. (1859) Beiträge zur Kenntniss der Ameisenfauna der Mittelmeerländer. I. Berliner Entomologische Zeitschrift, 3, 225-259.

Roger, J. (1863a) Die neu aufgeführten Gattungen und Arten meines Formiciden-Verzeichnisses nebst Ergänzung einiger früher gegebenen Beschreibungen. Berliner Entomologische Zeitschrift, 7, 131-214.

Ross, K.G. \& Trager, J.C. (1991 (“1990”)) Systematics and population genetics of fire ants (Solenopsis saevissima complex) from Argentina. Evolution, 44, 2113-2134.

Ryti, R.T. \& Case, T.J. (1988) Field experiments of desert ants: testing for competition between colonies. Ecology, 69, 1993-2003.

Sameshima, S., Hasegawa, E., Kitade, O., Minaka, N. \& Matsumoto, T. (1999) Phylogenetic comparison of endosymbionts with their host ants based on molecular evidence. Zoological Science (Tokyo), 16, 993-1000.

Sanders, N.J. \& Gordon, D.M. (2002) Resources and the flexible allocation of work in the desert ant, Aphaenogaster cockerelli. Insectes Sociaux, 49, 371-379.

Sanders, N.J., Barton, K.E. \& Gordon, D.M. (2001) Long-term dynamics of the distribution of the invasive Argentine ant, Linepithema humile, and native ant taxa in northern California. Oecologia (Berlin), 127, 123-130.

Sanetra, M. \& Buschinger, A. (2000) Phylogenetic relationships among social parasites and their hosts in the ant tribe Tetramoriini (Hymenoptera: Formicidae). European Journal of Entomology, 97, 95-117.

Santschi, F. (1914a (“1913”)) Mélanges myrmecologiques. Annales de la Société Entomologique de Belgique, 57, 429-437.

Saporito, R.A., Garraffo, H.M., Donnelly, M.A., Edwards, A.L., Longino, J.T. \& Daly, J.W. (2004) Formicine ants: an arthropod source for the pumiliotoxin alkaloids of dendrobatid poison frogs. Proceedings of the National Academy of Sciences of the United States of America, 101, 80458050 .

Sauer, C., Stackebrandt, E., Gadau, J., Hölldobler, B. \& Gross, R. (2000) Systematic relationships and cospeciation of bacterial endosymbionts and their carpenter ant host species: proposal of the new taxon Candidatus Blochmannia gen. nov. International Journal of Systematic \& Evolutionary Microbiology, 50, 1877-1886.

Savolainen, R. (1998) Evolution of social parasitism in Formica ants. [Abstract.] In: Schwarz, M. P. \& Hogendoorn, K. (Eds), Social insects at the turn of the millenium. Proceedings of the XIII International Congress of IUSSI. Adelaide, Australia. 29 December 1998 - 3 January 1999. XIII Congress of IUSSI, Adelaide, p. 417.

Savolainen, R. (2002) Phylogenetic relationships of Lasius, and the evolution of parasitic colony founding. [Abstract.] In: XIV International Congress of IUSSI. The Golden Jubilee Proceedings. 27 July - 3 August 2002, Hokkaido University, Sapporo, Japan. XIV International Congress of IUSSI, Sapporo, p. 159.

Say, T. (1836) Descriptions of new species of North American Hymenoptera, and observations on some already described. Boston Journal of Natural History, 1, 209-305.

Scheffrahn, R.H., Gaston, L.K., Sims, J.J. \& Rust, M.K. (1984) Defensive ecology of Forelius foetidus and its chemosystematic relationship to F. (=Iridomyrmex) pruinosus (Hymenoptera: Formicidae: Dolichoderinae). Environmental Entomology, 13, 1502-1506.

Scheffrahn, R.H. \& Rust, M.K. (1989) Attraction by semiochemical mediators and major exocrine 
products of the myrmicine ant, Crematogaster californica Emery. Southwestern Entomologist, $14,49-55$.

Schmidt, J.O. (1998) Pogonomyrmex ants: is possession of the world's most lethal arthropod venom a genus-wide trait? [Abstract.] In: Schwarz, M. P. \& Hogendoorn, K. (Eds.), Social insects at the turn of the millenium. Proceedings of the XIII International Congress of IUSSI. Adelaide, Australia. 29 December 1998 - 3 January 1999. XIII Congress of IUSSI, Adelaide, p. 425.

Schultz, T.R., Solomon, S.A., Mueller, U.G., Villesen, P., Boomsma, J.J., Adams, R.M.M. \& Norden, B. (2002) Cryptic speciation in the fungus-growing ants Cyphomyrmex longiscapus Weber and Cyphomyrmex muelleri Schultz and Solomon, new species (Formicidae, Attini). Insectes Sociaux, 49, 331-343.

Schulz, A. (1994) Aphaenogaster graeca nova species (Hym: Formicidae) aus dem Olymp-Gebirge (Griechenland) und eine Gliederung der Gattung Aphaenogaster. Beiträge zur Entomologie, 44, 417-429.

Seifert, B. (1988a) A revision of the European species of the ant subgenus Chthonolasius (Insecta, Hymenoptera, Formicidae). Entomologische Abhandlungen. Staatliches Museum für Tierkunde Dresden, 51, 143-180.

Seifert, B. (1988b) A taxonomic revision of the Myrmica species of Europe, Asia Minor, and Caucasia (Hymenoptera, Formicidae). Abhandlungen und Berichte des Naturkundemuseums Görlitz, 62(3), 1-75.

Seifert, B. (1992b) A taxonomic revision of the Palaearctic members of the ant subgenus Lasius s.str. (Hymenoptera: Formicidae). Abhandlungen und Berichte des Naturkundemuseums Görlitz, 66(5), 1-67.

Seifert, B. (2003) The ant genus Cardiocondyla (Insecta: Hymenoptera: Formicidae) - a taxonomic revision of the C. elegans, $C$. bulgarica, C. batesii, C. nuda, C. shuckardi, C. stambuloffii, $C$. wroughtonii, C. emeryi, and C. minutior species groups. Annalen des Naturhistorischen Museums in Wien. B, Botanik, Zoologie, 104, 203-338.

Shapley, H. (1920) Thermokinetics of Liometopum apiculatum Mayr. Proceedings of the National Academy of Sciences of the United States of America, 6, 204-211.

Shattuck, S.O. (1987) An analysis of geographic variation in the Pogonomyrmex occidentalis complex (Hymenoptera: Formicidae). Psyche (Cambridge), 94, 159-179.

Shattuck, S.O. (1992a) Review of the dolichoderine ant genus Iridomyrmex Mayr with descriptions of three new genera (Hymenoptera: Formicidae). Journal of the Australian Entomological Society, 31, 13-18.

Shattuck, S.O. (1992c) Generic revision of the ant subfamily Dolichoderinae (Hymenoptera: Formicidae). Sociobiology, 21, 1-181.

Shuckard, W.E. (1840a) Monograph of the Dorylidae, a family of the Hymenoptera Heterogyna. Annals of Natural History, 5, 188-201.

Smith, D.R. (1979) Superfamily Formicoidea. In: Krombein, K. V., Hurd, P. D., Smith, D. R. \& Burks, B.D. (Eds), Catalog of Hymenoptera in America north of Mexico. Volume 2. Apocrita (Aculeata). Smithsonian Institution Press, Washington, D.C., pp. 1323-1467.

Smith, F. (1851) List of the specimens of British animals in the collection of the British Museum. Part VI. Hymenoptera, Aculeata. British Museum, London, 134 pp.

Smith, F. (1855c) Descriptions of some species of Brazilian ants belonging to the genera Pseudomyrma, Eciton and Myrmica (with observations on their economy by Mr. H. W. Bates). Transactions of the Entomological Society of London, (2)3, 156-169.

Smith, F. (1858a) Catalogue of hymenopterous insects in the collection of the British Museum. Part VI. Formicidae. British Museum, London, 216 pp.

Smith, F. (1859c) Catalogue of hymenopterous insects in the collection of the British Museum. Part VII. Dorylidae and Thynnidae. British Museum, London, 76 pp. 
Smith, F. (1861b) Catalogue of hymenopterous insects collected by Mr. A. R. Wallace in the islands of Ceram, Celebes, Ternate, and Gilolo. [part] Journal and Proceedings of the Linnean Society of London. Zoology, 6, 36-48.

Smith, M.R. (1923b) Two new varieties of ants (Hymen.: Formicidae). Entomological News, 34, 306-308.

Smith, M.R. (1939c) Notes on Leptothorax (Mychothorax) hirticornis Emery, and description of a related new species (Formicidae). Proceedings of the Entomological Society of Washington, 41, 176-180.

Smith, M.R. (1939f) Notes on Formica (Neoformica) moki Wheeler, with description of a new subspecies (Hymenoptera: Formicidae). Annals of the Entomological Society of America, 32, 581584.

Smith, M.R. (1941) Two new species of Aphaenogaster (Hymenoptera: Formicidae). Great Basin Naturalist, 2, 118-121.

Smith, M.R. (1942b) The males of two North American cerapachyine ants. Proceedings of the Entomological Society of Washington, 44, 62-64.

Smith, M.R. (1943a (“1942”)) A new North American Solenopsis (Diplorhoptrum) (Hymenoptera: Formicidae). Proceedings of the Entomological Society of Washington, 45, 209-211.

Smith, M.R. (1943b) Ants of the genus Tetramorium in the United States with the description of a new species. Proceedings of the Entomological Society of Washington, 45, 1-5.

Smith, M.R. (1943f) A new male legionary ant from the Mojave Desert, California. Lloydia, 6, 196-197.

Smith, M.R. (1948) A new species of Myrmecina from California (Hymenoptera, Formicidae). Proceedings of the Entomological Society of Washington, 50, 238-240.

Smith, M.R. (1949e) A new Leptothorax commonly inhabiting the canyon live oak of California (Hymenoptera: Formicidae). Psyche (Cambridge), 56, 112-115.

Smith, M.R. (1951c) Family Formicidae. In: Muesebeck, C. F., Krombein, K. V. \& Townes, H. K. (Eds), Hymenoptera of America north of Mexico. Synoptic catalogue. United States Department of Agriculture. Agriculture Monograph, 2, pp. 778-875.

Smith, M.R. (1951d) Two new ants from western Nevada (Hymenoptera, Formicidae). Great Basin Naturalist, 11, 91-96.

Smith, M.R. (1954b ("1953")) A new Camponotus in California apparently inhabiting live oak, Quercus sp. (Hymenoptera, Formicidae). Journal of the New York Entomological Society, 61, 211-214.

Smith, M.R. (1956a) A key to the workers of Veromessor Forel of the United States and the description of a new subspecies (Hymenoptera, Formicidae). Pan-Pacific Entomologist, 32, 36-38.

Smith, M.R. (1957b) Revision of the genus Stenamma Westwood in America north of Mexico (Hymenoptera, Formicidae). American Midland Naturalist, 57, 133-174.

Smith, M.R. (1958b ("1957")) A contribution to the taxonomy, distribution and biology of the vagrant ant, Plagiolepis alluaudi Emery (Hymenoptera, Formicidae). Journal of the New York Entomological Society, 65, 195-198.

Smith, M.R. (1963c) A new species of Aphaenogaster (Attomyrma) from the western United States (Hymenoptera: Formicidae). Journal of the New York Entomological Society, 71, 244-246.

Smith, M.R. (1965) House-infesting ants of the eastern United States. Their recognition, biology, and economic importance. United States Department of Agriculture. Technical Bulletin, 1326, $1-105$.

Snelling, G.C. \& Snelling, R.R. (2005) New synonymy, new species, new keys to Neivamyrmex army ants of the United States. Memoirs of the American Entomological Institute, in press.

Snelling, R.R. (1965a) Studies on California ants. 1. Leptothorax hirticornis Emery, a new host and descriptions of the female and ergatoid male (Hymenoptera: Formicidae). Bulletin of the Southern California Academy of Sciences, 64, 16-21. 
Snelling, R.R. (1965b) Studies on California ants. 2. Myrmecina californica M. R. Smith (Hymenoptera; Formicidae). Bulletin of the Southern California Academy of Sciences, 64, 101-105.

Snelling, R.R. (1967) Studies on California ants. 3. The taxonomic status of Proceratium californicum Cook (Hymenoptera: Formicidae). Contributions in Science (Los Angeles), 124, 1-10.

Snelling, R.R. (1968b) Studies on California ants. 4. Two species of Camponotus (Hymenoptera: Formicidae). Proceedings of the Entomological Society of Washington, 70, 350-358.

Snelling, R.R. (1969b) Taxonomic notes on the Myrmecocystus melliger complex (Hymenoptera: Formicidae). Contributions in Science (Los Angeles), 170, 1-9.

Snelling, R.R. (1970) Studies on California ants, 5. Revisionary notes on some species of Camponotus, subgenus Tanaemyrmex (Hymenoptera: Formicidae). Proceedings of the Entomological Society of Washington, 72, 390-397.

Snelling, R.R. (1971a) Studies on California ants. 6. Three new species of Myrmecocystus (Hymenoptera: Formicidae). Contributions in Science (Los Angeles), 214, 1-16.

Snelling, R.R. (1973c) Studies on California ants. 7. The genus Stenamma (Hymenoptera: Formicidae). Contributions in Science (Los Angeles), 245, 1-38.

Snelling, R.R. (1974) Studies on California ants. 8. A new species of Cardiocondyla (Hymenoptera: Formicidae). Journal of the New York Entomological Society, 82, 76-81.

Snelling, R.R. (1976) A revision of the honey ants, genus Myrmecocystus (Hymenoptera: Formicidae). Natural History Museum of Los Angeles County. Science Bulletin, 24, 1-163.

Snelling, R.R. (1982a ("1981")) The taxonomy and distribution of some North American Pogonomyrmex and descriptions of two new species (Hymenoptera: Formicidae). Bulletin of the Southern California Academy of Sciences, 80, 97-112.

Snelling, R.R. (1982b) A revision of the honey ants, genus Myrmecocystus, first supplement (Hymenoptera: Formicidae). Bulletin of the Southern California Academy of Sciences, 81, 6986.

Snelling, R.R. (1988) Taxonomic notes on Nearctic species of Camponotus, subgenus Myrmentoma (Hymenoptera: Formicidae). In: Trager, J. C. (Ed), Advances in myrmecology. E. J. Brill, Leiden, pp. 55-78.

Snelling, R.R. (1992b) A newly adventive ant of the genus Pheidole in southern California (Hymenoptera: Formicidae). Bulletin of the Southern California Academy of Sciences, 91, $121-125$.

Snelling, R.R. (1995a) Systematics of Nearctic ants of the genus Dorymyrmex (Hymenoptera: Formicidae). Contributions in Science (Los Angeles), 454, 1-14.

Snelling, R.R. \& Buren, W.F. (1985) Description of a new species of slave-making ant in the Formica sanguinea group (Hymenoptera: Formicidae). Great Lakes Entomologist, 18, 69-78.

Snelling, R.R. \& George, C.D. (1979) The taxonomy, distribution and ecology of California desert ants. Report to California Desert Plan Program, Bureau of Land Management, U.S. Dept. Interior. 335 pp. +89 pp.

Snelling, R.R. \& Longino, J.T. (1992) Revisionary notes on the fungus-growing ants of the genus Cyphomyrmex, rimosus group (Hymenoptera: Formicidae: Attini). In: Quintero, D. \& Aiello, A. (Eds), Insects of Panama and Mesoamerica: selected studies. Oxford University Press, Oxford, pp. 479-494.

Starks, P.T., Watson, R.E., Dipaola, M.J. \& Dipaola, C.P. (1998) The effect of queen number on nestmate discrimination in the facultatively polygynous ant Pseudomyrmex pallidus (Hymenoptera: Formicidae). Ethology, 104, 573-584.

Steiner, F.M., Schlick-Steiner, B.C., Trager, J.C., Moder, K., Sanetra, M., Christian, E. \& Stauffer, C. (2005) Tetramorium tsushimae, a new invasive ant in North America. Biological Invasions, in press.

Stuart, R.J. \& Page, R.E., Jr. (1991) Genetic component to division of labor among workers of a 
leptothoracine ant. Naturwissenschaften, 78, 375-377.

Suarez, A.V., Bolger, D. T. \& Case, T.J. (1998) Effects of fragmentation and invasion on native ant communities in coastal southern California. Ecology, 79, 2041-2056.

Suarez, A. V., Holway, D.A. \& Case, T. J. (2001) Patterns of spread in biological invasions dominated by long-distance jump dispersal: insights from Argentine ants. Proceedings of the National Academy of Sciences of the United States of America, 98, 1095-1100.

Suarez, A.V., Tsutsui, N.D., Holway, D.A. \& Case, T.J. (1999) Behavioral and genetic differentiation between native and introduced populations of the Argentine ant. Biological Invasions, 1, 43-53.

Taber, S.W. (1990) Cladistic phylogeny of the North American species complexes of Pogonomyrmex (Hymenoptera: Formicidae). Annals of the Entomological Society of America, 83, 307-316.

Taber, S.W. (1998) The world of harvester ants. Texas A\&M University Press, College Station, Texas, xvii + $213 \mathrm{pp}$.

Taber, S.W. (2000) Fire ants. Texas A\&M University Press, College Station, Texas, xvii + 368 pp.

Taber, S.W., Cokendolpher, J. C. \& Francke, O. F. (1987) Scanning electron microscopic study of North American Pogonomyrmex (Hymenoptera: Formicidae). Proceedings of the Entomological Society of Washington, 89, 512-526.

Taber, S.W., Cokendolpher, J.C. \& Francke, O.F. (1988) Karyological study of North American Pogonomyrmex (Hymenoptera: Formicidae). Insectes Sociaux, 35, 47-60.

Taylor, R.W. (1967a) A monographic revision of the ant genus Ponera Latreille (Hymenoptera: Formicidae). Pacific Insects Monograph, 13, 1-112.

Thompson, C.R. (1989) The thief ants, Solenopsis molesta group, of Florida (Hymenoptera: Formicidae). Florida Entomologist, 72, 268-283.

Topoff, H. (1990) The evolution of slave-making behavior in the parasitic ant genus Polyergus. Ethology Ecology and Evolution, 2, 284-287.

Topoff, H. (1999) Slave-making queens. Scientific American, 281(5), 84-90.

Trager, J.C. (1984b) A revision of the genus Paratrechina (Hymenoptera: Formicidae) of the continental United States. Sociobiology, 9, 49-162.

Trager, J.C. (1988a) A revision of Conomyrma (Hymenoptera: Formicidae) from the southeastern United States, especially Florida, with keys to the species. Florida Entomologist, 71, 11-29.

Trager, J.C. (1991) A revision of the fire ants, Solenopsis geminata group (Hymenoptera: Formicidae: Myrmicinae). Journal of the New York Entomological Society, 99, 141-198.

Trager, J.C., MacGown, J.A. \& Trager, M.D. (2005) A revision of the Nearctic endemic Formica pallidefulva group. Memoirs of the American Entomological Institute, in press.

Traniello, J.F.A. (1978) Caste in a primitive ant: absence of age polyethism in Amblyopone. Science (Washington, D. C), 202, 770-772.

Traniello, J.F.A. (1982) Population structure and social organization in the primitive ant Amblyopone pallipes (Hymenoptera: Formicidae). Psyche (Cambridge), 89, 65-80.

Tschinkel, W.R. (1987) Seasonal life history and nest architecture of a winter-active ant, Prenolepis imparis. Insectes Sociaux, 34, 143-164.

Tsuji, K., Furukawa, T., Kinomura, K., Takamine, H. \& Yamauchi, K. (1991) The caste system of the dolichoderine ant Technomyrmex albipes (Hymenoptera: Formicidae): morphological description of queens, workers and reproductively active intercastes. Insectes Sociaux, 38, 413-422.

Tsutsui, N.D. \& Case, T.J. (2001) Population genetics and colony structure of the Argentine ant (Linepithema humile) in its native and introduced ranges. Evolution, 55, 976-985.

Tsutsui, N.D., Suarez, A.V. \& Grosberg, R.K. (2003) Genetic diversity, asymmetrical aggression, and recognition in a widespread invasive species. Proceedings of the National Academy of Sciences of the United States of America, 100, 1078-1083. 
Tsutsui, N.D., Suarez, A.V., Holway, D.A. \& Case, T.J. (2000) Reduced genetic variation and the success of an invasive species. Proceedings of the National Academy of Sciences of the United States of America, 97, 5948-5953.

Ulloa-Chacón, P. \& Cherix, D. (1990) The little fire ant Wasmannia auropunctata (R.) (Hymenoptera: Formicidae). In: Vander Meer, R. K., Jaffe, K. \& Cedeno, A. (Eds.), Applied myrmecology: a world perspective. Westview Press, Boulder, pp. 281-289.

Umphrey, G.J. (1996) Morphometric discrimination among sibling species in the fulva-rudis-texana complex of the ant genus Aphaenogaster (Hymenoptera: Formicidae). Canadian Journal of Zoology, 74, 528-559.

Umphrey, G.J. \& Danzmann, R.G. (1998) Electrophoretic evidence for hybridization in the ant genus Acanthomyops (Hymenoptera: Formicidae). Biochemical Systematics and Ecology, 26, 431-440.

Vega, S.J. \& Rust, M.J. (2001) The Argentine ant - a significant invasive species in agricultural, urban and natural environments. Sociobiology, 37, 3-25.

Viereck, H.L. (1903) Hymenoptera of Beulah, New Mexico. [part] Transactions of the American Entomological Society, 29, 56-87.

Walsh, B.D. (1863 ("1862")) On the genera of Aphidae found in the United States. Proceedings of the Entomological Society of Philadelphia, 1, 294-311.

Wang, J.S. \& Brook, T. S. (1970) Toxicological and biological studies of the odorous house ant, Tapinoma sessile. Journal of Economic Entomology, 63, 1971-1973.

Ward, P.S. (1985b) The Nearctic species of the genus Pseudomyrmex (Hymenoptera: Formicidae). Quaestiones Entomologicae, 21, 209-246.

Ward, P.S. (1987) Distribution of the introduced Argentine ant (Iridomyrmex humilis) in natural habitats of the lower Sacramento Valley and its effects on the indigenous ant fauna. Hilgardia, $55(2), 1-16$

Ward, P.S. (1988) Mesic elements in the western Nearctic ant fauna: taxonomic and biological notes on Amblyopone, Proceratium, and Smithistruma (Hymenoptera: Formicidae). Journal of the Kansas Entomological Society, 61, 102-124.

Ward, P.S. (1989a) Systematic studies on pseudomyrmecine ants: revision of the Pseudomyrmex oculatus and $P$. subtilissimus species groups, with taxonomic comments on other species. Quaestiones Entomologicae, 25, 393-468.

Ward, P.S. (1993) Systematic studies on Pseudomyrmex acacia-ants (Hymenoptera: Formicidae: Pseudomyrmecinae). Journal of Hymenoptera Research, 2, 117-168.

Ward, P.S. (1999) Deceptive similarity in army ants of the genus Neivamyrmex (Hymenoptera: Formicidae): taxonomy, distribution and biology of N. californicus (Mayr) and N. nigrescens (Cresson). Journal of Hymenoptera Research, 8, 74-97.

Ward, P.S. (2000) On the identity of Pheidole vaslitii Pergande (Hymenoptera: Formicidae), a neglected ant from Baja California. Journal of Hymenoptera Research, 9, 85-98.

Ward, P.S. (2005) The ant genus Leptanilloides: discovery of the male and evaluation of phylogenetic relationships based on DNA sequence data. Memoirs of the American Entomological Institute, in press.

Ward, P.S., Bolton, B., Shattuck, S.O. \& Brown, W.L., Jr. (1996) A bibliography of ant systematics. University of California Publications in Entomology, 116, 1-417.

Waser, N. (1998) Task-matching and short-term size shifts in foragers of the harvester ant, Messor pergandei (Hymenoptera: Formicidae). Journal of Insect Behavior, 11, 451-462.

Watkins, J.F., II. (1972) The taxonomy of Neivamyrmex texanus, n. sp., N. nigrescens and N. californicus (Formicidae: Dorylinae), with distribution map and keys to the species of Neivamyrmex of the United States. Journal of the Kansas Entomological Society, 45, 347-372.

Watkins, J.F., II. (1976) The identification and distribution of New World army ants (Dorylinae: Formicidae). Baylor University Press, Waco, Texas, 102 pp. 
Watkins, J.F., II. (1977b) Neivamyrmex nyensis, n. sp. (Formicidae: Dorylinae) from Nye County, Nevada, U.S.A. Southwestern Naturalist, 22, 421-425.

Watkins, J.F., II. (1985) The identification and distribution of the army ants of the United States of America (Hymenoptera, Formicidae, Ecitoninae). Journal of the Kansas Entomological Society, 58, 479-502.

Weber, N.A. (1939b) Description of new North American species and subspecies of Myrmica Latreille (Hym.: Formicidae). Lloydia, 2, 144-152.

Weber, N.A. (1947b) A revision of the North American ants of the genus Myrmica Latreille with a synopsis of the Palearctic species. I. Annals of the Entomological Society of America, 40, 437474.

Weber, N.A. (1948a) A revision of the North American ants of the genus Myrmica Latreille with a synopsis of the Palearctic species. II. Annals of the Entomological Society of America, 41, 267308.

Weber, N.A. (1950c) A revision of the North American ants of the genus Myrmica Latreille with a synopsis of the Palearctic species. III. Annals of the Entomological Society of America, 43, 189-226.

Weber, N.A. (1972) Gardening ants, the attines. American Philosophical Society, Philadelphia, xvii $+146 \mathrm{pp}$.

Went, F.W., Wheeler, J. \& Wheeler, G. C. (1972) Feeding and digestion in some ants (Veromessor and Manica). BioScience, 22, 82-88.

Wesmael, C. (1838) Sur une nouvelle espèce de fourmi du Mexique. Bulletin de l'Académie Royale des Sciences et Belles-Lettres de Bruxelles, 5, 766-771.

Wetterer, J.K., Miller, S.E., Wheeler, D.E., Olson, C.A., Polhemus, D.A., Pitts, M., Ashton, I.W., Himler, A.G., Yospin, M.M., Helms, K.R., Harken, E.L., Gallaher, J., Dunning, C.E., Nelson, M., Litsinger, J., Southern, A. \& Burgess, T.L. (1999) Ecological dominance by Paratrechina longicornis (Hymenoptera: Formicidae), an invasive tramp ant, in Biosphere 2. Florida Entomologist, 82, 381-388.

Wetterer, J.K. \& Porter, S.D. (2003) The little fire ant, Wasmannia auropunctata: distribution, impact, and control. Sociobiology, 42, 1-41.

Wetterer, J. K., Ward, P. S., Wetterer, A. L., Longino, J. T., Trager, J. C. \& Miller, S. E. (2000) Ants (Hymenoptera: Formicidae) of Santa Cruz Island, California. Bulletin of the Southern California Academy of Sciences, 99, 25-31.

Wheeler, D.E. \& Krutzsch, P.H. (1994) Ultrastructure of the spermatheca and its associated gland in the ant Crematogaster opuntiae (Hymenoptera, Formicidae). Zoomorphology (Berlin), 114, 203-212.

Wheeler, G.C. \& Wheeler, J. (1968b) The rediscovery of Manica parasitica (Hymenoptera: Formicidae). Pan-Pacific Entomologist, 44, 71-72.

Wheeler, G.C. \& Wheeler, J. (1970a) The natural history of Manica (Hymenoptera: Formicidae). Journal of the Kansas Entomological Society, 43, 129-162.

Wheeler, G.C. \& Wheeler, J. (1973e) Ants of Deep Canyon. University of California, Riverside, California, xiii +162 pp.

Wheeler, G.C. \& Wheeler, J. (1984a) The larvae of the army ants (Hymenoptera: Formicidae): a revision. Journal of the Kansas Entomological Society, 57, 263-275.

Wheeler, G.C. \& Wheeler, J. (1986g) The ants of Nevada. Natural History Museum of Los Angeles County, Los Angeles, vii + 138 pp.

Wheeler, J. (1968) Male genitalia and the taxonomy of Polyergus (Hymenoptera: Formicidae). Proceedings of the Entomological Society of Washington, 70, 156-164.

Wheeler, J. \& Rissing, S.W. (1975a) Natural history of Veromessor pergandei. I. The nest (Hymenoptera: Formicidae). Pan-Pacific Entomologist, 51, 205-216.

Wheeler, J. \& Rissing, S.W. (1975b) Natural history of Veromessor pergandei. II. Behavior 
(Hymenoptera: Formicidae). Pan-Pacific Entomologist, 51, 303-314.

Wheeler, W.M. (1902a) A new agricultural ant from Texas, with remarks on the known North American species. American Naturalist, 36, 85-100.

Wheeler, W.M. (1902b) Formica fusca Linn. subsp. subpolita Mayr, var. perpilosa, n. var. Memorias y Revista de la Sociedad Científica "Antonio Alzate”, 17, 141-142.

Wheeler, W.M. (1902d) New agricultural ants from Texas. Psyche (Cambridge), 9, 387-393.

Wheeler, W.M. (1902e) An American Cerapachys, with remarks on the affinities of the Cerapachyinae. Biological Bulletin (Woods Hole), 3, 181-191.

Wheeler, W.M. (1903d) A revision of the North American ants of the genus Leptothorax Mayr. Proceedings of the Academy of Natural Sciences of Philadelphia, 55, 215-260.

Wheeler, W.M. (1903g) Extraordinary females in three species of Formica, with remarks on mutation in the Formicidae. Bulletin of the American Museum of Natural History, 19, 639-651.

Wheeler, W.M. (1903j) Some notes on the habits of Ceraphachys augustae. Psyche (Cambridge), $10,205-209$.

Wheeler, W.M. (1904e) Ants from Catalina Island, California. Bulletin of the American Museum of Natural History, 20, 269-271.

Wheeler, W.M. (1904i) A new type of social parasitism among ants. Bulletin of the American Museum of Natural History, 20, 347-375.

Wheeler, W.M. (1905h) The North American ants of the genus Liometopum. Bulletin of the American Museum of Natural History, 21, 321-333.

Wheeler, W.M. (1906i) The ants of the Grand Cañon. Bulletin of the American Museum of Natural History, 22, 329-345.

Wheeler, W.M. (1908a) The ants of Porto Rico and the Virgin Islands. Bulletin of the American Museum of Natural History, 24, 117-158.

Wheeler, W.M. (1908g) Honey ants, with a revision of the American Myrmecocysti. Bulletin of the American Museum of Natural History, 24, 345-397.

Wheeler, W.M. (1908h) The ants of Texas, New Mexico and Arizona. (Part I) Bulletin of the American Museum of Natural History, 24, 399-485.

Wheeler, W.M. (1909e) A decade of North American Formicidae. Journal of the New York Entomological Society, 17, 77-90.

Wheeler, W.M. (1909f) A new honey ant from California. Journal of the New York Entomological Society, 17, 98-99.

Wheeler, W.M. (1910g) The North American ants of the genus Camponotus Mayr. Annals of the New York Academy of Sciences, 20, 295-354.

Wheeler, W.M. (1910h) The North American forms of Lasius umbratus Nylander. Psyche (Cambridge), 17, 235-243.

Wheeler, W.M. (1911d) A new Camponotus from California. Journal of the New York Entomological Society, 19, 96-98.

Wheeler, W.M. (1912c) New names for some ants of the genus Formica. Psyche (Cambridge), 19, 90.

Wheeler, W.M. (1912e) Additions to our knowledge of the ants of the genus Myrmecocystus Wesmael. Psyche (Cambridge), 19, 172-181.

Wheeler, W.M. (1913i) A revision of the ants of the genus Formica (Linné) Mayr. Bulletin of the Museum of Comparative Zoology, 53, 379-565.

Wheeler, W.M. (1914e) The American species of Myrmica allied to M. rubida Latreille. Psyche (Cambridge), 21, 118-122.

Wheeler, W.M. (1914f) New and little known harvesting ants of the genus Pogonomyrmex. Psyche (Cambridge), 21, 149-157.

Wheeler, W.M. (1915b) Some additions to the North American ant-fauna. Bulletin of the American Museum of Natural History, 34, 389-421. 
Wheeler, W.M. (1915i (“1914”)) The ants of the Baltic Amber. Schriften der Physikalisch-Ökonomischen Gesellschaft zu Königsberg, 55, 1-142.

Wheeler, W.M. (1917a) The mountain ants of western North America. Proceedings of the American Academy of Arts and Sciences, 52, 457-569.

Wheeler, W.M. (1919h) A new paper-making Crematogaster from the southeastern United States. Psyche (Cambridge), 26, 107-112.

Wheeler, W.M. (1930c) The ant Prenolepis imparis Say. Annals of the Entomological Society of America, 23, 1-26.

Wheeler, W.M. \& Creighton, W. S. (1934) A study of the ant genera Novomessor and Veromessor. Proceedings of the American Academy of Arts and Sciences, 69, 341-387.

Wild, A.W. (2002) A suspicious Prenolepis. Notes from Underground, 9, 14.

Wilson, E.O. (1954a ("1953”)) The ecology of some North American dacetine ants. Annals of the Entomological Society of America, 46, 479-495.

Wilson, E.O. (1955a) A monographic revision of the ant genus Lasius. Bulletin of the Museum of Comparative Zoology, 113, 1-201.

Wilson, E.O. (2003) Pheidole in the New World. A dominant, hyperdiverse ant genus. Harvard University Press, Cambridge, Massachusetts, [ix] + 794 pp.

Wilson, E.O. \& Brown, W.L., Jr. (1955) Revisionary notes on the sanguinea and neogagates groups of the ant genus Formica. Psyche (Cambridge), 62, 108-129.

Wilson, E.O. \& Taylor, R.W. (1967b) The ants of Polynesia (Hymenoptera: Formicidae). Pacific Insects Monograph, 14, 1-109.

Wing, M. W. (1968a) Taxonomic revision of the Nearctic genus Acanthomyops (Hymenoptera: Formicidae). Memoirs of the Cornell University Agricultural Experiment Station, 405, 1-173.

Yamauchi, K., Furukawa, T., Kinomura, K., Takamine, H. \& Tsuji, K. (1991) Secondary polygyny by inbred wingless sexuals in the dolichoderine ant Technomyrmex albipes. Behavioral Ecology and Sociobiology, 29, 313-319.

Yensen, N., Yensen, E. \& Yensen, D. (1980) Intertidal ants from the Gulf of California, Mexico. Annals of the Entomological Society of America, 73, 266-269. 

cally by subfamily and genus.

Species

Amblyoponinae

Amblyopone oregonensis (Wheeler 1915b)

Amblyopone pallipes (Haldeman 1844)

Cerapachyinae

Cerapachys augustae Wheeler 1902e

Cerapachys davisi M. R. Smith 1942b

Dolichoderinae

Dorymyrmex bicolor Wheeler 1906i

Dorymyrmex flavus McCook 1880

Dorymyrmex insanus (Buckley 1866)

Dorymyrmex sp. CA-01

Forelius mccooki (McCook 1880)

Forelius pruinosus (Roger 1863a)

Linepithema humile (Mayr 1868b)

Liometopum luctuosum Wheeler 1905h

Liometopum occidentale Emery 1895d

Tapinoma melanocephalum (Fabricius 1793)

Tapinoma sessile (Say 1836)

Technomyrmex sp. cf. albipes (F. Smith 1861b)

Ecitoninae

Neivamyrmex californicus (Mayr 1870b)

Neivamyrmex leonardi (Wheeler 1915b)

Neivamyrmex minor (Cresson 1872)

Neivamyrmex mojave (M. R. Smith 1943f)

Neivamyrmex nigrescens (Cresson 1872)

Neivamyrmex nyensis Watkins $1977 \mathrm{~b}$

Neivamyrmex opacithorax (Emery 1894d)

Neivamyrmex pilosus mexicanus (F. Smith 1859c)

Neivamyrmex swainsonii (Shuckard 1840a)

Neivamyrmex sp. CA-01

Formicinae

Brachymyrmex depilis Emery 1893k

Camponotus anthrax Wheeler 1911d

Camponotus bakeri Wheeler 1904e

Camponotus clarithorax Creighton 1950a

Camponotus dumetorum Wheeler 1910g

Status Notes

Species is known from males only.

Evidence of occasional introgression with $D$. insanus.

I? Probably introduced into California (Snelling 1995a).

Evidence of occasional introgression with $F$. pruinosus.

Probably conspecific with $N$. minor. Species is known from males only. Species is known from males only.

E1 Description in preparation (Snelling \& Snelling 2005).

E2

E1, E2

E2 Based on unavailable name clarithorax Emery 1893k.

E2 
Camponotus essigi M. R. Smith 1923b

Camponotus hyatti Emery 1893k

Camponotus laevigatus (F. Smith 1858a)

Camponotus maritimus Ward, sp. nov.

Camponotus modoc Wheeler 1910g

Camponotus ocreatus Emery 1893k

Camponotus quercicola M. R. Smith 1954b

Camponotus sansabeanus (Buckley 1866)

Camponotus sayi Emery 1893k

Camponotus semitestaceus Snelling 1970

Camponotus vicinus Mayr 1870b

Camponotus yogi Wheeler 1915b

Camponotus sp. CA-01

Camponotus sp. CA-02

Formica accreta Francoeur 1973

Formica adamsi whymperi Wheeler 1917a

Formica aerata Francoeur 1973

Formica altipetens Wheeler 1913i

Formica argentea Wheeler 1912c

Formica aserva Forel 19011

Formica canadensis Santschi 1914a

Formica dakotensis Emery 1893k

Formica densiventris Viereck 1903

Formica francoeuri Bolton 1995

Formica fusca Linnaeus 1758

Formica gnava Buckley 1866

Formica hewitti Wheeler 1917a

Formica integroides Wheeler 1913i

Formica lasioides Emery 1893k

Formica lepida Wheeler 1913i

Formica longipilosa Francoeur 1973

Formica manni Wheeler 1913i

Formica microphthalma Francoeur 1973

Formica moki Wheeler 1906i

Formica neoclara Emery 1893k

Formica neogagates Viereck 1903

Formica neorufibarbis Emery 1893k

Formica nevadensis Wheeler 1904i

Formica obscuripes Forel 1886b

Formica oreas Wheeler 1903g

Formica pacifica Francoeur 1973

Formica perpilosa Wheeler 1913i

Based on unavailable name semitestaceus Emery 1893k.

E2

E2

E2

Replacement name for pilicornis Emery 1893k.

Based on unavailable name integroides Emery 1893k.

E1, E2

E1, E2

Based on unavailable name whymperi Forel 1904b.

Replacement name for argentata Wheeler 1902e.
Based on unavailable name neogagates Emery 1893k.

Based on unavailable name perpi- 
Formica podzolica Francoeur 1973

Formica propinqua Creighton 1940a

Formica puberula Emery 1893k

Formica ravida Creighton 1940a

Formica sibylla Wheeler $1913 \mathrm{i}$

Formica sp. cf. sibylla

Formica subelongata Francoeur 1973

Formica subnitens Creighton 1940a

Formica subpolita Mayr 1886d

Formica transmontanis Francoeur 1973

Formica xerophila M. R. Smith 1939 f

Formica sp. CA-01

Lasius alienus (Foerster 1850a)

Lasius atopus Cole 1958a

Lasius sp. cf. atopus

Lasius californicus Wheeler 1917a

Lasius crypticus Wilson 1955a

Lasius flavus (Fabricius 1782)

Lasius humilis Wheeler 1917a

Lasius latipes (Walsh 1863)

Lasius murphyi Forel 1901j

Lasius neoniger Emery 1893k

Lasius niger (Linnaeus 1758)

Lasius pallitarsis (Provancher 1881b)

Lasius subumbratus Viereck 1903

Lasius umbratus (Nylander 1846b)

Lasius vestitus Wheeler 1910h

Lasius sp. CA-01

Myrmecocystus christineae Snelling 1982b

Myrmecocystus colei Snelling 1976

Myrmecocystus creightoni Snelling 1971a

Myrmecocystus ewarti Snelling 1971a

Myrmecocystus flaviceps Wheeler 1912e

Myrmecocystus hammettensis Cole 1938b

Myrmecocystus kathjuli Snelling 1976

Myrmecocystus kennedyi Snelling 1969b

Myrmecocystus koso Snelling 1976

Myrmecocystus lugubris Wheeler $1909 \mathrm{f}$

Myrmecocystus mendax Wheeler 1908g

Myrmecocystus mexicanus Wesmael 1838

Myrmecocystus mimicus Wheeler $1908 \mathrm{~g}$

Myrmecocystus navajo Wheeler $1908 \mathrm{~g}$ losa Wheeler 1902b.

California records from Francoeur (1973:168).

Based on unavailable name propinqua Wheeler 1917a.

Based on unavailable name ravida Wheeler 1913i.

E1, E2

E2

In the $F$. microgyna subgroup, within the $F$. rufa-group.

E1, E2

$\mathrm{E} 1, \mathrm{E} 2$

E2

I? Possibly introduced into California (Wilson 1955a).

E2 Near L. umbratus; known only from queens and males.

E1

E1, E2

E2

E1

Based on unavailable name kennedyi Cole 1936b. 
Myrmecocystus placodops Forel 1908c

Myrmecocystus romainei Hunt \& Snelling 1975

Myrmecocystus semirufus Emery 1893k

Myrmecocystus tenuinodis Snelling 1976

Myrmecocystus testaceus Emery 1893k

Myrmecocystus wheeleri Snelling 1971a

Myrmecocystus yuma Wheeler 1912e

Paratrechina hystrix Trager 1984b

Paratrechina longicornis (Latreille 1802a)

Paratrechina sp. cf. terricola

Paratrechina vividula (Nylander 1846a)

Paratrechina sp. CA-01

Plagiolepis alluaudi Emery 1894b

Polyergus breviceps Emery 1893k

Prenolepis imparis (Say 1836)

Prenolepis sp. CA-01

Based on unavailable name

E2

E2

I

I? Considered native to Texas and

E1, E2

I

E1, E2

Myrmicinae

Acromyrmex versicolor (Pergande 1893)

Aphaenogaster boulderensis M. R. Smith 1941

Aphaenogaster cockerelli André 1893b

Aphaenogaster megommata M. R. Smith 1963c

Aphaenogaster occidentalis (Emery 1895d)

Aphaenogaster patruelis Forel 1886b

Aphaenogaster uinta Wheeler 1917a

Cardiocondyla mauritanica Forel 1890b

I

Cardiocondyla minutior Forel 1899a

Crematogaster californica Wheeler 1919h

Crematogaster coarctata Mayr 1870 b

Crematogaster depilis Wheeler 1919h

Crematogaster hespera Buren 1968b

Crematogaster larreae Buren 1968b

Crematogaster marioni Buren 1968b

Crematogaster mormonum Wheeler 1919h

E2

Crematogaster mutans Buren 1968b

Crematogaster opuntiae Buren 1968b

Cyphomyrmex flavidus Pergande 1896

Cyphomyrmex wheeleri Forel 1900h

Formicoxenus diversipilosus (M. R. Smith 1939c)

Leptothorax calderoni Creighton 1950a

Leptothorax sp. CA-01

Based on unavailable name calderoni Forel 1914c.

Represents one or more species in the muscorum complex. 
Manica parasitica (Creighton 1934)

Messor andrei (Mayr 1886d)

Messor chamberlini Wheeler 1915b

Messor chicoensis (M. R. Smith 1956a)

Messor lariversi (M. R. Smith 1951d)

Messor pergandei (Mayr 1886d)

Messor smithi (Cole 1963a)

Messor stoddardi (Emery 1895d)

Monomorium ergatogyna Wheeler 1904e

Monomorium pharaonis (Linnaeus 1758)

Monomorium sp. nr. pharaonis

Myrmecina americana Emery 1895d

Myrmica americana Weber 1939b

Myrmica discontinua Weber 1939b

Myrmica glacialis Emery 1921c

Myrmica incompleta Provancher 1881b

Myrmica rugiventris (M. R. Smith 1943b)

Myrmica tahoensis Weber 1948a

Myrmica sp. CA-01

Pheidole barbata Wheeler 1908h

Pheidole bicarinata Mayr 1870b

Pheidole californica Mayr 1870b

Pheidole cerebrosior Wheeler 1915b

Pheidole clementensis Gregg 1969b

Pheidole clydei Gregg 1950

Pheidole creightoni Gregg 1955a

Pheidole desertorum Wheeler 1906i

Pheidole fervens $\mathrm{F}$. Smith 1858a

Pheidole gilvescens Creighton \& Gregg 1955

Pheidole hyatti Emery 1895d

Pheidole micula Wheeler 1915b

Pheidole moerens Wheeler 1908a

Pheidole paiute Gregg 1959

Pheidole pilifera (Roger 1863a)

Pheidole psammophila Creighton \& Gregg 1955

Pheidole rugulosa Gregg 1959

Pheidole sciophila Wheeler 1908h

Pheidole teneriffana Forel $1893 \mathrm{f}$

Pheidole vistana Forel 1914d

Pheidole xerophila Wheeler 1908h

Pheidole yaqui Creighton \& Gregg 1955

Pogonomyrmex anzensis Cole 1968

Replacement name for mutica Emery 1895 d.

E1, E2

$\mathrm{E} 2$

E1, E2

$\mathrm{E} 1, \mathrm{E} 2$

E2

I

I

E2

I
Based on unavailable name gilvescens Wheeler 1908h

Based on unavailable name glacialis Forel 1904b.

Based on unavailable name tahoensis Wheeler 1917a.

E1, E2

May be a distinct species, pacifica Wheeler 1915b, in CA. 
Pogonomyrmex imberbiculus Wheeler 1902a

Pogonomyrmex magnacanthus Cole 1968

Pogonomyrmex maricopa Wheeler $1914 \mathrm{f}$

Pogonomyrmex montanus MacKay 1980

Pogonomyrmex occidentalis (Cresson 1865b)

Pogonomyrmex rugosus Emery 1895d

Pogonomyrmex salinus Olsen 1934

Pogonomyrmex subdentatus Mayr 1870b

Pogonomyrmex subnitidus Emery 1895d

Pogonomyrmex tenuispinus Forel 1914d

Pyramica californica (Brown 1950d)

Pyramica membranifera (Emery 1869b)

Pyramica reliquia (Ward 1988)

Rogeria sp. CA-01

Solenopsidini, gen. nov., sp. nov.

Solenopsis amblychila Wheeler 1915b

Solenopsis aurea Wheeler 1906i

Solenopsis invicta Buren 1972

Solenopsis molesta (Say 1836)

Solenopsis salina Wheeler 1908h

Solenopsis tennesseensis M. R. Smith 1951c

Solenopsis texana catalinae Wheeler 1904e

Solenopsis truncorum Forel 1901j

Solenopsis xyloni McCook 1880

Solenopsis sp. CA-01

Stenamma californicum Snelling 1973c

Stenamma diecki Emery 1895d

Stenamma sp. cf. diecki

E1, E2

I

E1, E2

$\mathrm{E} 1, \mathrm{E} 2$

I

$\mathrm{E} 1, \mathrm{E} 2$

E1, E2

$\mathrm{E} 1, \mathrm{E} 2$

E2

$\mathrm{E} 1, \mathrm{E} 2$

E1, E2

$\mathrm{E} 1, \mathrm{E} 2$

E1, E2

$\mathrm{E} 1, \mathrm{E} 2$

E1, E2

Occurrence in California needs confirmation.

Stenamma exasperatum Snelling 1973c

Stenamma sp. cf. heathi

Stenamma punctatoventre Snelling 1973c

Stenamma sp. $1 \mathrm{cf}$. punctatoventre

Stenamma sp. 2 cf. punctatoventre

Stenamma sp. 3 cf. punctatoventre

Description in preparation (Cover \& Deyrup 2005).

California "aurea" may be light-colored S. xyloni.

Identification of species as molesta needs confirmation.

Replacement name for longiceps $\mathrm{M}$. R. Smith 1943a.

Taxonomic status of catalinae is unclear.

Replacement name for occidentale 
Stenamma sp. cf. snellingi

Stenamma sp. CA-01

Strumigenys silvestrii Emery 1906c

Temnothorax andrei (Emery 1895d)

Temnothorax chandleri (Mackay 2000)

Temnothorax gallae (M. R. Smith 1949e)

Temnothorax neomexicanus (Wheeler 1903d)

Temnothorax nevadensis (Wheeler 1903d)

Temnothorax nitens (Emery 1895d)

Temnothorax oxynodis (Mackay 2000)

Temnothorax rudis (Wheeler 1917a)

Temnothorax rugatulus (Emery 1895d)

Temnothorax whitfordi (Mackay 2000)

Temnothorax sp. CA-01

Temnothorax sp. CA-02

Temnothorax sp. CA-03

Temnothorax sp. CA-04

Temnothorax sp. CA-05

Temnothorax sp. CA-06

Temnothorax sp. CA-07

Temnothorax sp. CA-08

Temnothorax sp. CA-09

Temnothorax sp. CA-10

Tetramorium bicarinatum (Nylander 1846b)

Tetramorium caespitum (Linnaeus 1758)

Tetramorium insolens (F. Smith 1861b)

Tetramorium pacificum Mayr 1870b

Tetramorium simillimum (F. Smith 1851)

Tetramorium spinosum (Pergande 1896)

Wasmannia auropunctata (Roger 1863a)

Ponerinae

Hypoponera opaciceps (Mayr 1887)

Hypoponera opacior (Forel 1893j)

Hypoponera punctatissima (Roger 1859)

Hypoponera sp. CA-01

Proceratiinae

Proceratium californicum Cook 1953

Pseudomyrmecinae

Pseudomyrmex apache Creighton 1953b

Pseudomyrmex pallidus (F. Smith 1855c)
M. R. Smith 1957b.

E1, E2
I

E1, E2 May be conspecific with T. nitens.

E2

E1, E2

E2 Leptothorax sp. nr. silvestrii of Johnson \& Ward (2002).

E2 Leptothorax sp. BCA-2 of Johnson \& Ward (2002).

E2 Leptothorax sp. BCA-3 of Johnson \& Ward (2002).

E1, E2

$\mathrm{E} 1, \mathrm{E} 2$

E2 Leptothorax sp. BCA-9 of Johnson \& Ward (2002).

E1, E2

I

I

I

I

I

I

I?

I

E1, E2

* E1 = endemic to California; E2 = endemic to California floristic province (Hickman, 1993); I = introduced species. 